University of Louisville

ThinkIR: The University of Louisville's Institutional Repository

Electronic Theses and Dissertations

$12-2016$

\title{
Challenging conventional wisdom : section 8 housing and the real impact on neighborhood values in Louisville, Kentucky.
}

\author{
Paul Francis Dries \\ University of Louisville
}

Follow this and additional works at: https://ir.library.louisville.edu/etd

Part of the Urban Studies and Planning Commons

\section{Recommended Citation}

Dries, Paul Francis, "Challenging conventional wisdom : section 8 housing and the real impact on neighborhood values in Louisville, Kentucky." (2016). Electronic Theses and Dissertations. Paper 2606. https://doi.org/10.18297/etd/2606

This Doctoral Dissertation is brought to you for free and open access by ThinkIR: The University of Louisville's Institutional Repository. It has been accepted for inclusion in Electronic Theses and Dissertations by an authorized administrator of ThinkIR: The University of Louisville's Institutional Repository. This title appears here courtesy of the author, who has retained all other copyrights. For more information, please contact thinkir@louisville.edu. 


\title{
CHALLENGING CONVENTIONAL WISDOM: SECTION 8 HOUSING AND THE REAL IMPACT ON NEIGHBORHOOD VALUES IN LOUISVILLE, KY
}

\author{
By \\ Paul Francis Dries \\ B.S., University of Louisville, 1981 \\ M. Eng., University of Louisville, 1982 \\ M.B.A., Loyola University New Orleans, 1987

\begin{abstract}
A Dissertation
Submitted to the Faculty of the

College of Arts and Sciences of the University of Louisville

In Partial Fulfillment of the Requirements

For the Degree of
\end{abstract} \\ Doctor of Philosophy in Urban and Public Affairs \\ Department of Urban and Public Affairs \\ University of Louisville \\ Louisville, Kentucky
}

December 2016 
Copyright 2016 by Paul Francis Dries

All rights reserved 



\title{
CHALLENGING CONVENTIONAL WISDOM: SECTION 8 HOUSING AND THE REAL IMPACT ON NEIGHBORHOOD VALUES IN LOUISVILLE, KY
}

\author{
By \\ Paul Francis Dries \\ B.S., University of Louisville, 1981 \\ M. Eng., University of Louisville, 1982 \\ M.B.A., Loyola University New Orleans, 1987
}

A Dissertation Approved On

October 24, 2016

By the following Dissertation Committee:

Dissertation Director, Dr. John Gilderbloom, Ph.D.

Professor Carrie Donald, J.D.

Dr. Steven Koven, Ph.D.

Dr. Aaron Rollins, Ph.D.

Dr. Matthew Hanka, Ph.D. 


\section{DEDICATION}

To Diann, my wife and best friend 


\section{ACKNOWLEDGEMENTS}

There are many people who helped me to cross the finish line, most importantly Dr. John Gilderbloom whose guidance and assistance made the completion of this project possible. I also want to thank my other committee members, Drs. Matt Hanka, Steven Koven, Aaron Rollins, and Professor Carrie Donald whose input was necessary and greatly appreciated.

During a particularly discouraging period, Dr. Janet Kelly encouraged me to continue and matriculate, and for that I am grateful. I want to recognize a member of my cohort at the university, Dr. Sarin Adhikari, who helped me in many ways to get to this point along with Chad Frederick who helped with some of the analysis.

This dissertation used a valuable data set that was provided by Dr. Gilderbloom, and I would like to thank him for allowing me to use this data and expand the research associated with that information.

No thank you would be complete without mentioning my wife Diann and my children, Mary and Michael. They offered support and would not let me stop without completing my degree. 


\section{ABSTRACT \\ CHALLENGING CONVENTIONAL WISDOM: SECTION 8 HOUSING AND THE REAL IMPACT ON NEIGHBORHOOD VALUES IN LOUISVILLE, KY

\author{
Paul F Dries
}

October 24, 2016

Section 8 Housing was designed to de-concentrate poverty and spread affordable housing across communities. There are many studies that have evaluated the successes associated with the policy of dispersing the urban poor to the surrounding suburban areas in various cities. The positive impacts of dispersing the urban poor, in terms of education, self-esteem, and jobs, is well documented. There are fewer studies related to the potential externalities associated with these programs.

This study uses advanced multiple regression techniques to study 170 Louisville neighborhoods to look at whether large concentrations of Section 8 housing have a negative impact on neighborhood housing values. It was found that large concentrations of Section 8 depress neighborhood values in poor neighborhoods even more, but Section 8 does not diminish the value in wealthy neighborhoods. This was done by using a split regression analysis. Additional research was carried out by interviewing landlords on attitudes toward Section 8. It turns out that their views were mixed. Finally, research techniques were done using GIS mapping techniques to see how Section 8 is concentrated in mostly poor and minority neighborhoods. 
This is a study of one city in the United States. This study could be replicated in cities similar to Louisville, Kentucky to determine if these findings can be found at other locations as well. Further research is needed to determine the unknown factors that cause the results to be mixed. 


\section{TABLE OF CONTENTS}

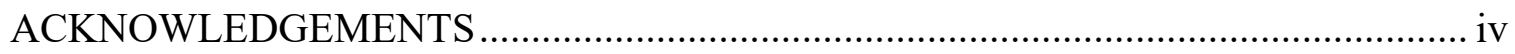

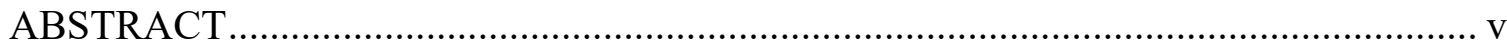

CHAPTER ONE - BACKGROUND ….............................................................. 1

What is Section 8 Housing? ................................................................................... 2

Unanswered Questions About Section 8 Housing ................................................ 4

Purpose and Importance of this Research ........................................................... 5

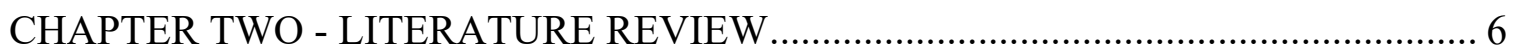

Divided Schools of Thought on Housing Options ........................................................ 6

Neighborhood Housing Dynamics.................................................................. 9

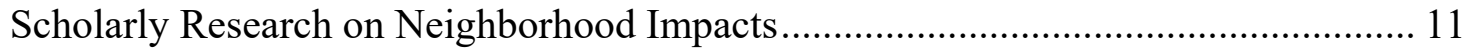

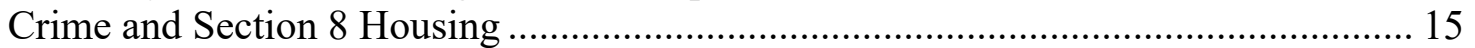

Utilization of the Same Dataset - Previous Research.............................................. 16

Why Louisville, Kentucky? ............................................................................. 18

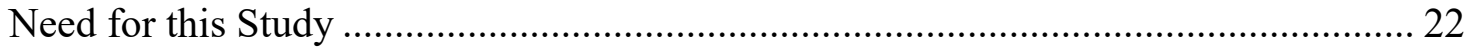

CHAPTER THREE - RESEARCH QUESTIONS, HYPOTHESES, and

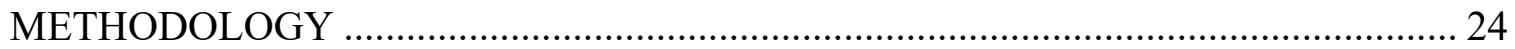

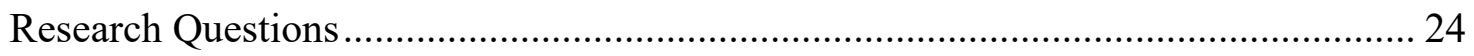

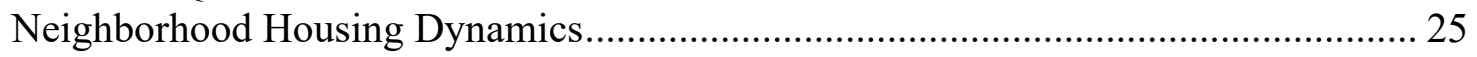

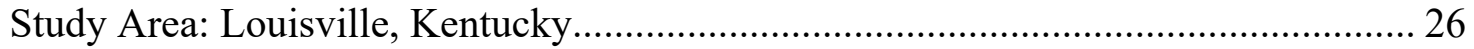

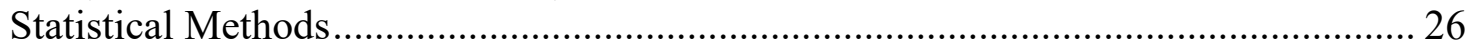

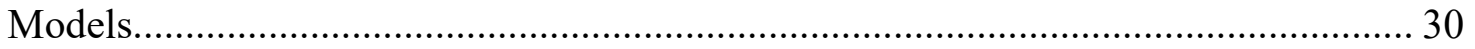

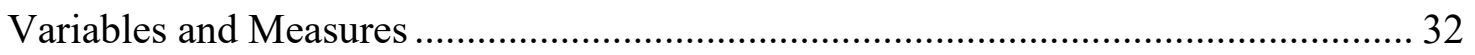

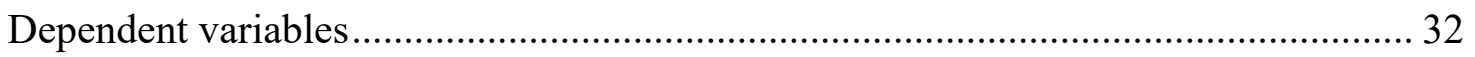

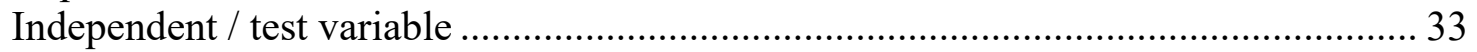

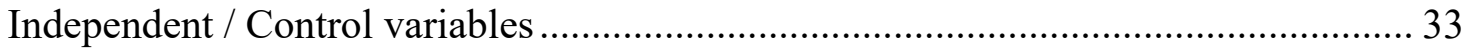

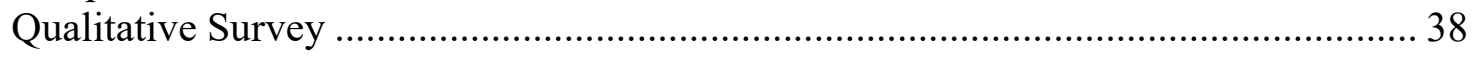

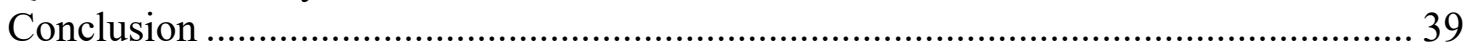

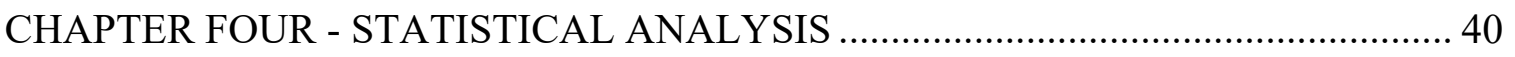

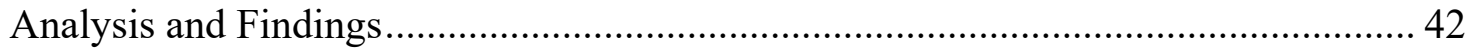

Model 1 - Mean Assessed Value for the years 2000, 2006, 2008, and 2010 ......... 42

Model 2 - Change in Mean Assessed Value over time .......................................... 45

Split Regression Section 8 density, most dense/least dense $-50 / 50$....................... 49

Split Regression Section 8 density, most dense/least dense - 75/25 …..................... 56

Split Regression Mean Assessed Value, high MAV/low MAV - 50/50..................... 63

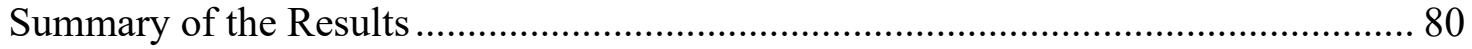


CHAPTER FIVE - QUALITATIVE SURVEY RESULTS ..................................... 81

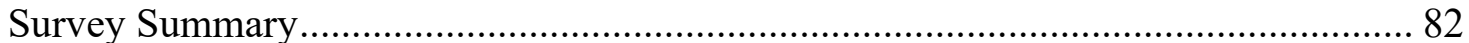

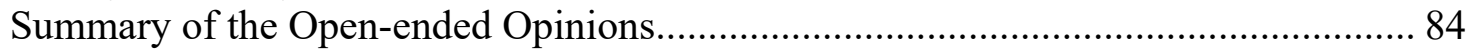

CHAPTER SIX - CONCLUSION AND DISCUSSION ........................................... 106

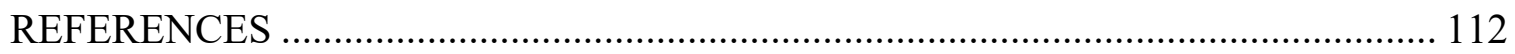

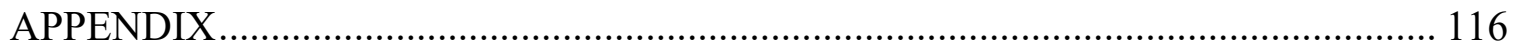

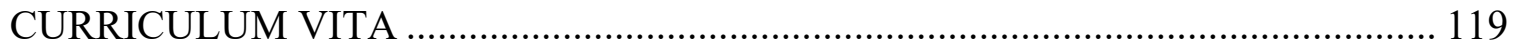




\section{LIST OF TABLES}

TABLE

Table 2.1 Descriptive Statistics:

Comparing Louisville to the 147 Largest US Cities .........

Table 3.1 Description of Dependent Variables .................... 36

Table 3.2 Description of Test and Independent Variables ............ 37

Table 4.1 Model 1 - Regression Models Summary -

Mean Assessed Values .................................. 44

Table 4.2 Model 2 - Change in Mean Assessed Value over time .... 47

Table 4.3 Descriptives for Total Dataset ........................ 48

Table 4.4 Model 3A - Split Regression Section 8 density $50 \%$ most dense

Table 4.5 Descriptives for Section 8 Density $-50 \%$ most dense........

Table 4.6 Model 3B - Split Regression Section 8 density $50 \%$ least dense

Table 4.7 Descriptives for Section 8 Density $-50 \%$ least dense.........

Table 4.8 Model 4A - Split Regression Section 8 density $75 \%$ most dense

Table 4.9 Model 4B - Split Regression Section 8 density $25 \%$ least dense

Table 4.10 Descriptives for Section 8 Density $-75 \%$ most dense........... 60

Table 4.11 Descriptives for Section 8 Density $-25 \%$ least dense.......... 61

Table 4.12 Model 5A - Split Regression Mean Assessed Value $50 \%$ most expensive 
Table 4.13 Descriptives for Mean Assessed Value, 2000 -

$50 \%$ most expensive ..................................

Table 4.14 Descriptives for Mean Assessed Value, 2006 -

$50 \%$ most expensive............................... 68

Table 4.15 Descriptives for Mean Assessed Value, 2008 -

$50 \%$ most expensive

Table 4.16 Descriptives for Mean Assessed Value, 2010 -

$50 \%$ most expensive.............................. 70

Table 4.17 Model 5B - Split Regression Mean Assessed Value -

$50 \%$ least expensive

Table 4.18 Descriptives for Mean Assessed Value, 2000 -

$50 \%$ least expensive

72

Table 4.19 Descriptives for Mean Assessed Value, 2006 -

$50 \%$ least expensive

Table 4.20 Descriptives for Mean Assessed Value, 2008 -

$50 \%$ least expensive

Table 4.21 Descriptives for Mean Assessed Value, 2010 -

$50 \%$ least expensive

75 


\section{LIST OF MAPS}

MAP

PAGE

Map 4.1 Section 8 Density Distribution .......................... 55

Map 4.2 Section 8 Density Distribution $-75 / 25 \ldots \ldots \ldots \ldots \ldots \ldots \ldots . . . .62$

Map 4.3 Mean Assessed Value Distribution, 2000 - 50/50 ...... 76

Map 4.4 Mean Assessed Value Distribution, 2006 - 50/50 ...... 77

Map 4.5 Mean Assessed Value Distribution, 2008 - 50/50 ...... 78

Map 4.6 Mean Assessed Value Distribution, 2010 - 50/50 ...... 79 


\section{CHAPTER ONE - BACKGROUND}

The purpose of this dissertation is to explore the impact of Section 8 housing location on neighborhood housing values in Louisville, Kentucky.

Louisville is a midsized mid-western city located on the Ohio River across from Indiana. In 2010, the most recent Census Report, Louisville had a population of 605,105 . Many studies have used megacities such as New York or Chicago as study areas; however, its moderate size and mid-western location make Louisville representative of the average US city (Gilderbloom, Ambrosius, Squires, Hanka, \& Kenitzer, 2012; Savitch \& Vogel, 2004).

The effects of the immediate environment on neighborhood attributes and neighborhood opportunity structures have long been studied by social scientists (Dreier, Mollenkopf \& Swanstrom, 2001; Jacobs, 1961; Logan \& Molotch, 1987; Sampson, 2012). These studies have contributed to the literature on the independent causal effects

of neighborhoods on social, environmental or health outcomes. Thus, Section 8 housing, and its potential impacts on surrounding neighborhoods, is relevant to planners and policymakers.

A prominent test of the hypothesis that neighborhoods affect individuals was tested via the Gautreaux program in Chicago. Researchers studied families moving from neighborhoods of concentrated poverty to neighborhoods of low poverty and found that, compared to families who remained in the original neighborhood, the individuals who 
were relocated experienced significant increases in health, education, safety and employment (Dreier et al., 2001; Galster \& Mikelsons, 1995; Popkin, Buron, Levy, \& Cunningham, 2000; Wilson, 2009). These studies inspired the Moving to Opportunity (MTO) program in the 1990s. Families utilizing this program received vouchers to move into different neighborhoods. The thesis was that the families would show significant gains on measures of employment, safety and health, and education. Some studies revealed significant gains for families who left neighborhoods of concentrated poverty in perceived mental health and safety (Goetz, 2003; Imbroscio, 2010). These increases are predictions. One problem with these studies is that they do not assess the potential impacts of these relocations on the receiving neighborhoods.

There is an increasing public demand to see data that confirms gains from government investments to improve communities. The desire for evidence of achievement has raised the bar for evaluation in these areas (Schweigert, 2006). One perception is that subsidized housing results in negative neighborhood impacts, specifically related to property values.

The purpose of this study is to utilize methodological bases for discerning impacts and determining results tied to valid information. This study seeks to provide evidence as to the specific impact of moving families from housing projects to subsidized rental properties in different neighborhoods.

What is Section 8 Housing?

The US Department of Housing and Urban Development (HUD) started the family self-sufficiency program in 1984. This initial program, named Project Self- 
Sufficiency, lasted until 1989. In 1989, it was renamed operation bootstrap and the program was expanded to include all families instead of just single mothers (Anthony, 2005). The Housing Choice Voucher Program (HCV) provided rental assistance for those wishing to locate in the private rental market instead of housing projects. The voucher program funds the difference between the federal government's established fair market rent and actual rent. This provision extends the location of Section 8 families into previously unaffordable neighborhoods (Song \& Keeling, 2010). Research on government studies has noted that providing voucher holders with increased mobility improves Section 8 housing recipients' lives considerably (Anthony, 2005; Brooks, Zugazaga, Wolk, \& Adams, 2005). HUD's website defines the program as follows:

"The housing choice voucher program is the federal government's major program for assisting very low-income families, the elderly, and the disabled to afford decent, safe, and sanitary housing in the private market. Since housing assistance is provided on behalf of the family or individual, participants are able to find their own housing, including single-family homes, townhouses and apartments."

However, improved environments for the poor are not guaranteed by housing vouchers alone. In the Louisville market, the Metro Housing Authority issues Section 8 housing vouchers to qualifying public assistance recipients. Recipients of approved Section 8 housing have no restrictions as to choice of location in Jefferson County. This provides a "geography of opportunity," allowing voucher recipients to work toward an improvement in lifestyle. The term "geography of opportunity" was proposed by Galster 
to refer to the various ways that opportunities are influenced by geography (Galster \& Mikelsons, 1995; Rosenbaum, Reynolds, \& Deluca, 2002), but this study seeks to understand the impact of these relocations on the market area that has been encroached upon by voucher recipients.

While many voucher users believe their houses, neighborhoods, and their overall living conditions improve with relocation (Brooks et al., 2005), citizens in receiving neighborhoods are often concerned that subsidized housing will harm property values, encourage white flight and increase crime rates (Freeman \& Botein, 2002).

\section{Unanswered Questions About Section 8 Housing}

Analysts have worked to assess the relative importance of providing effective subsidized housing for the nation's poor. Most agree that a subsidized housing policy should strive to improve access to opportunity, reduce poverty concentration and increase social integration. Policy makers debate the competing strategies of dispersal versus enrichment in place (Talen \& Koschinsky, 2014). The comparison of local neighborhoods identified as census tracts will provide a valuable understanding for explaining any variation in neighborhood property values that affect communities of Section 8 housing (Gilderbloom, Hanka, \& Ambrosius, 2012).

The idea of mixed income development has generated significant controversy and resistance from both sides of the aisle. The concept of gentrification is not without critiques that emphasize the negative impacts of mixed income development. The tension between exclusion and integration creates disagreements on what constitutes public space versus the nature and extent of rights in that space (Chaskin \& Joseph, 2013). The 
controversy is often linked to the values of housing units in the areas receiving Section 8 recipients. The unanswered question is whether Section 8 vouchers result in increases or decreases in property values on the surrounding housing stock.

\section{Purpose and Importance of this Research}

Quite a bit has been written about the positive potential of programs such as Section 8 housing; however, data of the impact on house values within receiving neighborhoods has not been readily available. Absent from the literature are case studies on Section 8 impacts of housing values, because the data to generate these studies has not been readily available. This dissertation seeks to fill this void by examining the impact of Section 8 housing on neighborhood housing valuation in Louisville Kentucky. This study will employ multivariate regressions using ordinary least squares technique to better understand how Section 8 may influence housing values in Louisville Kentucky, from 2000 to 2010.

Community initiatives are ambitious and expensive, representing major commitments by cities; therefore, particular attention is needed to evaluate large-scale community initiatives. This attention is needed because of the potential for social benefit and the scale of investment, which raises the stakes for demonstration of effectiveness (Schweigert, 2006). The researcher hopes that this examination will further evaluation of voucher programs in mid-size cities. 


\section{CHAPTER TWO - LITERATURE REVIEW}

Many scholars believe that regional governing of metro areas is necessary to reap the benefits of scale economy in service provision, to achieve equity across jurisdictions by standardizing policies that have area-wide impacts, and to internalize policy spillovers - both positive and negative across jurisdictional boundaries. These issues lie at the heart of how cities elect to deal with Section 8 housing opportunities. This chapter reviews arguments made in favor of polycentric and monocentric, organization of localities, and examines governing of metro areas through restructuring of metropolitan "government" versus non-structural metropolitan "governance" related to local housing options.

\section{Divided Schools of Thought on Housing Options}

Public choice proponents explain that the free market and individual mobility allow people to locate where their preferences are met (Ostrom \& Ostrom, 1971; Tiebout, 1956). Allowing this to occur freely in the market will be the most efficient use of urban land (Tiebout, 1956). This premise suggests that people will vote with their feet by moving to a neighborhood that meets individual preferences. Such a free-market view of mobility often results in a preference for sprawling developments. However, a number of scholars would take issue with this perspective (Downs, 1994; Dreier et al., 2001; Duany, Plater-Zyberk, \& Speck, 2000; Massey \& Denton, 1993). They argue that the market is not free; rather, all levels of government have intervened with the private market, which has resulted in the creation and perpetuation of sprawl's dominance of United States urban land development. The federal government has steered American development 
toward sprawl through a number of policies: first, through the use of redlining practices of mortgage insurance; second, through the subsidization of the highway system; and further, through tax incentives that reward and drive residents toward suburban developments and homeownership (Dreier et al., 2001; Williamson, 2010). Government intervention demonstrates that markets are not totally free and push development into sprawling suburbs through policies and incentives.

There have also been studies that examine individual preferences for neighborhoods and housing choices within those neighborhoods. Place has an enormous direct impact on an individual's success and life outcomes (Dreier, Mollenkopf, \& Swanstrom, 2004; Galster \& Mikelsons, 1995). Neighborhoods provide context for the socialization and development of families and represent structures of opportunity and/or inequality in action. In the lives of families and children, neighborhood effects have long been an important topic of research (Rosenbaum \& Deluca, 2008).

Tiebout argued that local governments would compete for residents through various service packages and types of costs. Populations would then be sorted across an urban area and eventually reach an equilibrium that would represent the efficient production of public goods (Tiebout, 1956). Following this, a model of urban dynamics created by Forrester (1989) concluded that cities providing services for the poor will attract low-income persons, and affluent persons will flee. (Forester, 1989).

Under polycentric assumptions, individuals with relatively similar preferences for public goods tend to cluster in homogeneous neighborhoods. Citizens live in multiple jurisdictions and the different scopes and skills of organization allow citizens to better make effective choices when selecting service packages most important them. The 
presence of large numbers of potential producers of urban goods and services allows elected officials to make more effective selections when choosing producers. These producers then search for innovative technologies and encourage greater efficiency in the production of goods and services due to competition. In a monocentric government it is the public goods and services that are relatively homogeneous. Therefore the services are not catered, as effectively, to the specific needs of individual citizens. The mechanism of articulating preferences is through one election as opposed to multiple elections in the polycentric model (Ostrom, 2000).

An alternative to the public choice theory role of government is proposed by the authors of Place Matters (Dreier et al., 2001). The authors espouse a regional governance approach in an attempt to minimize the impact and reduce the number of blighted urban areas occurring through economic segregation and concentrated poverty consequent to the public choice theory. Public choice theory places strong controls on the central authority; however, Place Matters advocates a public policy of dispersing the urban poor to the surrounding suburban areas. This may be accomplished by instituting an even larger role for the Federal government, while promoting regionalism of jurisdictions and redistribution policies (Dreier et al., 2001).

At the center of any concept of democratic control is the definition of democratic responsiveness. This responsiveness, or the shaping of local government policy to the preferences of the governed, varies considerably, depending upon which urban concept is in play. In the pluralistic theory, political forces are the mechanism that shape urban choices. This theory uses political logic as opposed to economic logic. Cities that operate, according to this metanarrative, behave as political entities, where coalitions are 
necessary for political success. In the United States, many cities behave in this manner (Stone, 1989). The physical result of individuals desiring control over the future is cities with polycentric governments and little overarching regional control.

Another modification that posits a method for ruling American cities is the growth machine theory. In this theory, a locality is conceived in the interests of land-based elite. These elites profit through the increasing intensification of land-use, and they compete with one another to have more resources invested in their own areas. Local governments are utilized to achieve this growth at the expense of competing locales, and community life is largely a consequence of the social, economic, and political forces embodied in the growth machine. The elites are those who participate with their energies and fortunes. These are the sorts of persons who have the most to gain or lose in land-use decisions (Logan \& Molotch, 1987; Molotch, 1976).

There is little question that the dynamic of capital accumulation is dominating urban policy, and with no national model for growth in the United States, it is not surprising that problems have resulted (Swanstrom, Dreier, \& Mollenkopf, 2002).

\section{Neighborhood Housing Dynamics}

Economic segregation in neighborhoods is a significant negative byproduct of pursuing a sprawl growth model. However, economic segregation is more than the separation of the middle class from the poor in suburbs versus inner city neighborhoods. Inside and outside most American cities are areas of low opportunity and high opportunity. The concept of neighborhood housing dynamics assists in the analysis of the effects of many social and economic activities in communities (Gilderbloom et al., 2012; 
Gilderbloom, Riggs, \& Meares, 2015; Hanka, Gilderbloom, Meares, Khan, \& Wresinski, 2015).

Economic segregation has been shown to be a significant determining factor to urban poverty across the United States (Dreier et al., 2001; Wilson, 1987, 2009). Economic segregation has been found to accelerate income inequalities between neighborhoods of low and high opportunity. This economic segregation plays havoc with the quality of life for poor residents.

This economic segregation produces two problems: 1) spatial mismatch between low income residents and job opportunities; 2) spatial mismatch in education. The poor often lack educational opportunities and access to entry-level and low-skilled jobs. The negative effects of these circumstances include joblessness, shortage of resources, and deteriorating neighborhood conditions.

Thus, there are two opposing models - a culture of opportunity model and a geography of opportunity model. These models result in different implications. The Gautreaux program studied these issues by looking at the experiences of low-income families through the lens of residential mobility or geography (Rosenbaum et al., 2002). One possible solution to this economic segregation is to disperse the impoverished individuals among higher income neighborhoods. Another solution is to invest resources in the downtrodden neighborhoods; therefore, bringing opportunity to the neighborhood without moving its residents. In either case, the central or Federal government has the basic responsibility of macroeconomic stabilization, national security, and income redistribution in the form of assistance to the poor (Oates, 1999). The US Department of Housing and Urban Development (HUD), in an effort to revitalize severely distressed 
public housing, created the HOPE VI program. The objectives of this program were to change the physical shape of public housing, to reduce poverty concentration, to provide community services, and to develop public-private partnerships (Hanka, Gilderbloom, Meares, Khan, \& Wresinski, 2015).

The potential costs of urban policy favoring residential mobility, specifically Moving to Opportunity (MTO), need to be determined. Few researchers believe that residential mobility is the sole solution to overcoming serious challenges faced by families in our poorest neighborhoods.

In the United States, many land-use issues need to be considered. Property rights are paramount as the citizens of the United States demand the right to occupy the property that is owned, and to sell, lease, or donate the property as they see fit. This includes the right to subdivide the property, the right to build or remove improvements, or the right to otherwise control the property's used within the bounds of the law. At the same time, the public retains certain rights related to private property. These rights include the right to assess and tax the property, the right to control its use, the right to acquire it for public use. These rights are retained by local, state, and Federal government. Public land-use control can facilitate economic development, and manage social and environmental problems as they occur.

\section{Scholarly Research on Neighborhood Impacts}

The idea of neighborhood effects dates back to the $19^{\text {th }}$ Century. Spatial explanations used by the Chicago School scholars described citizen interactions and city processes. Political economy theorists formulated ideas about the influence of capitalism 
and political forces onto neighborhood inequalities (Logan \& Molotch, 1987; Sampson, 2012). Studies in the early 20th century provided more focus on individual outcomes and behavior (Dreier et al., 2001; Wilson, 1987). More recently, the Gautreaux program showed that low-income individuals escaped a life of poverty and experienced improvements in employment, education and social integration, when integrated into middle and upper-class areas (Galster \& Mikelsons, 1995; Wilson, 2009).

Findings such as these influenced the "Moving to Opportunity" (MTO) programs in the 1990s. The MTO program sought to measure the life opportunities of low-income individuals. Results showed levels of perceived safety and mental health in participants' lives.

Why does subsidized housing have an impact on a given neighborhood? The character of the neighborhood can be defined by socioeconomic characteristics, its location and its housing stock. As evidenced by the existence of different zoning types, different housing stock affects neighborhoods. Subsidized housing does not have to be distinctive from other housing in neighborhoods. What makes subsidized housing distinctive is occupancy by low- income clientele, normally unable to afford housing in middle-income areas. This provides the source of much of the negative impressions regarding subsidized housing's impact on surrounding neighborhoods (Freeman \& Botein, 2002).

Planners have used many tools to facilitate development under the rubric of the comprehensive plan. The most common tool was use of zoning ordinances. Zoning divides the local jurisdiction into districts or zones, and it regulates the types of activities allowed. Such ordinances manage the intensity of land-use through the management of 
elements such as use standards, density standards, dimensional standards, development review procedures, appeal and variance provisions and enforcement provisions. While all of this sounds "value free" in concept, zoning has many limitations that can result in a less than ideal urban environment. Zoning can be exclusionary. Burns (1994) has postulated that zoning helped create racial segregation in many US cities. In fact, it appears that racial segregation was the goal of the zoning process in this period of our history. Normative planning values were at work within the confines of the value free system.

The purpose of comprehensive plans is to present development policy spatially. While the idea of comprehensive planning is good overall, and noble in nature, conventional comprehensive planning resulted in another social ill, besides segregation: sprawled development. Sprawl has occurred because of an increase in demand for land to be developed. This increase in demand creates pressure on environmentally sensitive lands that often exist on the outskirts of cities. There is a resulting increase in the cost of public infrastructure, such as new roads and utilities most often not paid by the developer (Molotch, 1976).

This normative view of society, as provided by the conventional comprehensive plan model, was considered outdated by some who desired a new planning system to provide a framework for zoning and land-use decisions that would assist the poor and others without political or economic power. One of the major goals of this new planning methodology, - advocacy planning, - was structured to provide citizens the ability to express their goals for the future of their communities. Davidoff was a force for equity and justice in planning. Advocacy planning was intended to improve conditions for 
citizens by using an emphasis on resources. This included the expansion of representation to include traditionally excluded groups in discussion (Checkoway, 1994). There was now a focus on interactions between different social groups. Attempts were made to manage these interactions and resulted in support for social justice. This formulation of social policy became part of the planning process.

The evolution of the planning process, from the rational comprehensive model to advocacy planning, created an improved understanding of how individual planners can impact the urban environment. The goal of planning needs to be the improvement of land uses so that citizen quality of life improves without damaging the quality of life elsewhere. Planners have the ability to broaden their traditional areas of concern beyond land use, zoning, and urban design by showing concern for low and moderate income citizens (Krumholz, 1999).

Creating sustainable neighborhoods is crucial to the future of successful urban planning. Sustainable neighborhoods are those in which there is a greater diversity of people and housing stock, with associated returns on investment of both monetary and human capital. One of the emerging topics related to sustainable communities is the concept of walkability. The benefits of a walkable community include increases in property values and decreases in housing foreclosures and crime - walk matters. Studies that develop policies for land use must address problems faced by the recipients of Section 8 housing, including efforts to redesign or revitalize low-income housing. Policies must include strategies that encourage development of more walkable and sustainable neighborhoods. 


\section{Crime and Section 8 Housing}

Crime is a common issue in the study of the social sciences. As this study is evaluating the effects of public housing, it should be noted that public housing is often associated with distressed properties and neighborhoods where disorder may prevail. Crime is one of the disorders present within the public housing arena.

A traditional source of social disorder is poverty. Typically, Section 8 housing units contain disadvantaged segments of society. This can be a function of federal guidelines as one of the requirements for a public housing applicant is that they be poor. A significant study on the relationship between homicide patterns and public housing was performed for the years 1989 through 2007 in Louisville Kentucky (Suresh \& Vito, 2009). In this study, the income level of residents and the presence of vacant housing are both predictors of homicide clusters. Children who grow up in an environment such as this may experience a paucity of working adults and therefore may underestimate or undervalue the value of the human capital return on education and success within the workforce (Wilson, 1996).

Within the traditional Section 8 housing model, where high-density low-income populations exist, there have been problems of negative peer influence referred to as the "contagion theory" (Goetz, 2003). The effects of peer influence can be either positive or negative. When neighborhood disorganization is prevalent, peer influence is often negative. A lack of social cohesion increases the rates of violent and property crimes within neighborhoods, while greater levels of social cohesion reduce the rates of property and violent crimes within the community (Donnelly \& Kimble, 1997). 
Exposure to violence and crime causes many innocent residents of assisted housing to become victims, isolated within their own homes because of fear. This isolation can reduce the size of social networks necessary to create an increase in desired human capital. Also, high-density housing complexes often add physical distance between residents and employment/educational opportunities. (Ellen \& Turner, 1997).

This earlier study found homicide hotspots in locations where housing assistance was concentrated in high-density areas of central cities. Unfortunately, when housing facilities were distributed throughout the larger community, a relationship between the location of Section 8 housing and homicide hotspots continued (Suresh \& Vito, 2009). The problem of homicide within the city of Louisville moved but was not eliminated.

\section{Utilization of the Same Dataset - Previous Research}

The data set utilized in this study has become a very valuable tool for the study of different urban issues in typical midsized US cities such as Louisville, Kentucky. At least three journal articles and one dissertation have utilized this data set, provided by Dr. J. I. Gilderbloom. Journals such as Cities, the Journal of Urban Affairs, and the American Review of Public Administration have published articles from the subject data since 2009.

Previous studies looked into the impacts of walkability on crime, foreclosures, and housing valuation. They have also studied neighborhood variation of foreclosures and the role of race in these foreclosures, as well as evaluating whether property tax assessments have been fair and without bias.

An examination of walkabiliy's impact on housing values, foreclosures and crime examined the 170 neighborhoods in Louisville Kentucky to see whether walkability 
influenced neighborhood sustainability. This is an important emerging topic in the wake of problems related to foreclosures, crime, and the potential decline in housing prices and how these activities negatively affect communities. A series of models were used to test the relationship between walkability and common variables used to measure the health of a community. This study revealed positive relationships between walkability and neighborhood housing valuation, and walkability and decreases in both crime and foreclosure rates (Gilderbloom, Riggs, \& Meares, 2015).

The second of these journal articles used the dataset to develop a better understanding of how foreclosures vary in defined neighborhoods in Louisville Kentucky. In recent history, the foreclosure epidemic moved throughout the community impacting all housing types and income levels, whereas the foreclosure problem has been commonly restricted to neighborhoods in the urban core (Leinberger, 2008). This study provided a very robust model for predicting foreclosures and indeed helped to better explain the contemporary causes of greater foreclosures in the African-American neighborhoods of Louisville (Gilderbloom et al., 2012).

A third article utilized the Gilderbloom dataset to study the reliability of tax assessment data in Louisville. This analysis focused on how self-provided housing values compare to assessed values and whether variations related to changes in neighborhood condition. These housing values were also compared to transaction prices during the same calendar year, to objectively analyze whether there are biases concerning race or class in property assessments. The study contradicted the conventional wisdom that property assessors exhibit biases and that the movers and shakers as a whole benefit from these under assessed properties. The study found that the neighborhood housing values in 
all neighborhoods compared favorably with the median prices calculated from MLS sales and U.S. Census data (Gilderbloom et al., 2012).

Studies such as these provide the tools necessary to encourage the development of policies supporting more sustainable neighborhoods. This study will build upon these earlier analyses by examining how housing values in Louisville are related to Section 8 housing location, while considering similar variables previously studied. The relationships to be studied will help to forge new understanding and will provide policy considerations that enable communities to create more sustainable conditions for their residents.

\section{Why Louisville, Kentucky?}

The researcher chose Louisville, Kentucky as the location for the case study. The city is known as Louisville Metro, having expanded its boundaries in 2003, when it merged with surrounding Jefferson County to form a consolidated government (Savitch \& Vogel, 2004). The data used is from the consolidated Metropolitan County rather than the former Louisville proper or the Metropolitan Statistical Area (MSA), which includes adjacent counties. The 2003 merger allows for an effective collection of data, without the need to distinguish between the historic former city of Louisville and the suburbs. Geographically, Louisville Metro is two concentric rings of suburban neighborhoods under one political jurisdiction.

Several studies have utilized Louisville as a study area (Ambrosius, Gilderbloom, \& Hanka, 2010; Appelbaum, 1976; Gilderbloom et al., 2012; Gilderbloom \& Appelbaum, 1988). The area is more monocentric than polycentric, with a range of neighborhood 
types. The city has become a valuable location for evaluation, because of the availability of extensive data. Data comes from several different sources, including the Jefferson County Property Valuation Administrator, the US Census Bureau, the EPA, and the Louisville Metro Police Department.

The unit of observation utilized in this study is the Census tract. The sample contains 170 tracts and covers the period between the years 2000 and 2010 . The regression analyses identify the number of census tracts in each individual case. The number of census tracts varies slightly in that there may be variables missing in a given census tract in a given year. If a variable is missing, that census tract is excluded from the regression as opposed to utilization of a data averaging technique. During this time frame, Louisville experienced a stable economic period as well as a period of recession. The data collected was geo-coded by the Kentucky State Data Center utilizing the Louisville/Jefferson County Information Consortium's GIS, known locally as the LOJIC system. The dependent variable was the Mean Assessed Residential Housing Value for the years 2000, 2006, 2008, and 2010. The dependent variable was then operationalized in an additional way as a value change in Median Assessed Value from the years 2000 to 2006 and 2008 to 2010 . The first period reflected a relatively stable period of economic growth, and the second period reflected a recessionary period.

According to the 2000 U.S. Census, there were 21 cities in the United States with a population between 500,000 and 1 million people. There have been many publications and studies related to urban issues in cities that have populations larger than this, but this research will help fill the gap with a study of a middle-sized city. Many of the larger cities have several interdependent housing markets, which make for complicated 
interactions between them. Louisville, a relatively monocentric city, has a uniform housing market that enables study across the entire area. Using US Census data, Louisville was compared to 147 of the largest cities in the United States. A head to head comparison of the independent variables is shown in Table 2.1 . The 148 city count in the United States includes Louisville. 
Table 2.1 Descriptive Statistics:

Comparing Louisville to the 147 Largest US Cities

\begin{tabular}{|c|c|c|c|c|c|}
\hline & \multicolumn{2}{|c|}{148 Largest US Cities } & \multicolumn{2}{|c|}{ Louisville, KY } & \multirow{2}{*}{$\begin{array}{r}\text { Delta } \\
\text { MEAN }\end{array}$} \\
\hline & $\underline{\mathrm{N}}$ & Mean & $\underline{\mathrm{N}}$ & $\underline{\text { Mean }}$ & \\
\hline Percentage of White Residents & 148 & 72 & 1 & 71 & 1 \\
\hline Percent of Houses Built Before 1949 & 148 & 21 & 1 & 25 & (4) \\
\hline Total Vacancy Rate - Percent & 148 & 13 & 1 & 12 & 1 \\
\hline Owner Vacancy Rate - Percent & 148 & 2.5 & 1 & 2.4 & 0 \\
\hline Rental Vacancy Rate - Percent & 148 & 7 & 1 & 8 & (1) \\
\hline Population - 2013 & 148 & 135,000 & 1 & 605,000 & $(470,000)$ \\
\hline Median Household Income & 148 & 48,170 & 1 & 50,039 & $(1,869)$ \\
\hline Percent Rentals & 148 & 47 & 1 & 40 & 7 \\
\hline
\end{tabular}


This comparison reveals why Louisville, Kentucky may well serve as a proxy for other US cities. The independent variables are very close to the averages in terms of racial diversity and housing ownership averages. The percentage of white residents on average in the 148 largest US cities is 72 percent, and Louisville has a population that is 71 percent white. Another variable that points to Louisville as a good study site is the median household income statistic. In 2013, Louisville's median household income was $\$ 50,039$ while the average median income for the 148 city sample was $\$ 48,170$.

These factors create a scenario where data is readily available and well structured. The relative consistency of the urban and suburban environments enable analysis that has proven robust in earlier studies. I have lived most of my life in this city and have developed land in many different areas. I am very familiar with the various areas of the city captured by these data. This enables a possibly deeper and more meaningful interpretation than could be obtained without this deeper understanding. The benefits of my experience will be more applicable with the qualitative component of my dissertation. The main thrust of this dissertation is the quantitative evaluation of the data set related to Section 8 housing. This evaluation however, will be supplemented with a qualitative component to provide confirmation of the veracity of the data.

\section{Need for this Study}

The literature on local intergovernmental relations paints an encouraging picture of scholarly interest in this research area. Scholars' goals should not be prescriptive, but use empirical findings to provide research solutions and true facts. 
The motive for doing this research related to Moving to Opportunity programs, specifically Section 8 vouchers, is to help answer policy questions of what is possible, what works and why, and what does not work and why not? An assessment of program costs and benefits needs to include an evaluation of the externalities linked to these programs. It is always important to remember that what researchers are looking to do is to determine what families need and to determine whether the current policies or programs are lacking in this regard.

The nature of planning has been that the practice is primarily local in nature with the goal of the improving quality of life. Planning is concerned with local group processes and the role of agency. There has been movement from an objective process to a more normative process. Initially planning was a function of the rational comprehensive plan concept. While planners still use the rational comprehensive plan, some now use advocacy planning, and others use an urban sustainability planning process. Over time, the shared goal of planning has become one of desirable outcomes (Fainstein \& Campbell, 2002).

The push for desirable outcomes requires planners to suggest how land developments should or ought to be. The theory shifted emphasis in planning theory, from outcomes to process and from consequences to consciousness. How planners value the implications brought on by their plans reflect the beliefs of individual planners and their desires, that is, normative planning results.

This literature review demonstrates the gap in scholarship concerning Section 8 housing median assessed property values. This study seeks to fill that gap through the research questions and the hypotheses used in the following chapters. 


\section{CHAPTER THREE - RESEARCH QUESTIONS, HYPOTHESES, and METHODOLOGY}

This dissertation seeks to explore the relationship between Section 8 housing and the associated neighborhood housing markets as defined by mean assessed values for the years 2000, 2006, 2008, and 2010.

\section{Research Questions}

Questions that have emerged from the literature review will be analyzed as follows:

- How does Section 8 housing affect mean assessed values of housing stock in the same census tract in a midsize city?

- Do the effects that are measured change over time? In other words, during periods of robust growth or during recessionary periods, are there changes in how the mean assessed value of the nearby housing stock varies with respect to proximity of Section 8 housing?

By exploring these questions, a better understanding of the impacts of relocating Section 8 housing within different neighborhoods may be achieved. Additionally, the exploration of the composition of the Section 8 neighborhoods will help to guide future policies related to the voucher program. 


\section{Neighborhood Housing Dynamics}

The questions above inspired the development of hypotheses in two areas of housing dynamics: 1) the impact of Section 8 housing on measures of housing values at a single point in time: and 2) the impact of Section 8 housing on measures of housing values over specific time periods. Both of these concepts will use Section 8 housing density per 1000 residents as the test variable.

$\mathrm{H}_{1}$ : Mean assessed value in a given year is more likely to be negatively impacted in neighborhoods with greater levels of Section 8 housing.

This study will be using census tract aggregated data to understand the impact of section 8 housing on mean assessed values during the given study years. Understanding the effect of Section 8 housing on housing valuation can enhance insight into the programs and policies that advocate for greater Section 8 housing availability out in the community.

$\mathrm{H}_{2}$ : The impact of percent change in mean assessed value between the years 2000 and 2006 will be greater than the percent change in the assessed value between the years 2006 and 2010 in the areas where section 8 housing is present.

Using multiple years for this study provides researchers the ability to examine changes over time related to the presence of Section 8 housing. The dates to be evaluated were chosen based upon the significance of the housing market crash in the years 2007 and 2008. The first time period between 2000 and 2006, reflects a time of significant growth within the Louisville marketplace. The second period, between years 2006 and 2010, overlaps a volatile economic time period, and provides a valuable secondary data 
point related to the impacts of Section 8 housing on the mean assessed values. This evaluation will help to determine if good or bad economic times have bigger impacts on the relationship between mean assessed values and Section 8 housing location.

The hypotheses explored in this dissertation will contribute insight into the housing characteristics of Section 8 neighborhoods. Results will identify the true impact of Section 8 housing, both positively and negatively, and contribute to current policy discourse.

\section{Study Area: Louisville, Kentucky}

Louisville, Kentucky is a city in the United States with a population greater than 50,000 that is not within 40 miles of a neighboring city of similar size (Gilderbloom et al., 2012). Louisville is representative of a typical US city and therefore provides a basis for an excellent case study. The characteristics of the urban landscape are considered by many to be the most representative demographically in the United States. Louisville's average size and relative isolation as compared to cities greater than 50,000 population, make it a very manageable study area for this type of analysis. Of course, research findings in the Louisville market are not necessarily representative of the nation as a whole, or of cities of similar size; however, a case study of the Louisville market can provide results that may be generalized and tested in other communities.

\section{Statistical Methods}

This dissertation will utilize linear regression techniques known as ordinary least squares regression (OLS) in an attempt to identify a linear relationship between the dependent variable and a set of independent variables. The linear regression equation in simple form can be represented as: 


$$
Y=\beta_{1} X_{1}+\beta_{2} X_{2}+\ldots \beta_{n} X_{n}+e
$$

Where $\mathrm{Y}$ is the dependent variable,

$\mathrm{X}_{1}, \mathrm{X}_{2} \ldots \mathrm{X}_{\mathrm{n}}$ are the independent or control variables as the case may be,

$\beta_{1}$ is the regression coefficient for $X_{1}$,

$\mathrm{n}$ is the number of independent variables used, and $\mathrm{e}$ is an error term.

The strength of OLS regression lies in its simplicity. It is a generalized linear modeling technique where the dependent variable is recorded on an interval scale, but the independent variable can be recorded in interval, ordinal or dummy format. This method provides the easiest way to predict the behavior of the dependent variable caused by a one or many independent and control variables. The relationship between any dependent variable ' $y$ ' and an independent variable ' $x$ ' can be represented in the form of an equation of a straight line as shown below:

$$
\begin{aligned}
& Y=f(x), \text { or } \\
& Y=b x+e,
\end{aligned}
$$

Where ' $b$ ' is the slope of the straight line and ' $\mathrm{e}$ ' is the error component. A positive value for ' $b$ ' suggests a positive correlation between ' $x$ ' and ' $y$,' whereas a negative value suggests an inverse relationship. The numerical value of the slope, which is also known as 'coefficient' can be represented in two different ways: unstandardized and standardized. An unstandardized coefficient represents the quantity by which the dependent variable ' $y$ ' changes when the independent variable ' $x$ ' changes by one unit. The numerical value of the coefficient depends upon the units by which the dependent and the independent variables are measured. Standardized coefficients, 
however, represent the percentage change in the dependent variable when the independent variable changes by one percent. Standardized coefficients are useful while comparing the individual effects of multiple independent variables on the dependent variable. The numerical value of a standardized coefficient ranges between a negative 1 to a positive 1 .

OLS regression makes it easier to interpret multivariate regression models. A multivariate regression can be understood as separate multiple equations of straight lines combined into one equation, commonly represented as:

$$
\mathrm{Y}=\mathrm{b}_{1} \mathrm{X}_{1}+\mathrm{b}_{2} \mathrm{X}_{2}+\mathrm{b}_{3} \mathrm{X}_{3}+\ldots \ldots \ldots+\mathrm{b}_{\mathrm{n}} \mathrm{X}_{\mathrm{n}}
$$

The coefficients of individual independent variables represent their individual effect on the dependent variable. In both the cases - univariate as well as multivariate - the coefficient (b) provides an indication of the average expected change in the dependent variable. A researcher's confidence in this change is important in the analysis. The confidence intervals for the estimate of a sufficiently large sample, that is a $95 \%$ twotailed approximation of the confidence interval, can be calculated as $\pm 1.96 *$ standard error $* b$

The OLS regression also provides information about how well the model fits that data. The observed values of ' $y$ ' in the dataset are compared to the values of ' $y$ ' predicted by the regression model. This difference between the observed and the predicted value of ' $y$ ' is called the residual. Adding up the squared (to remove negative values) residuals of all data points gives the residual sum of squares, or RSS, which tells us how closely the model fits with the data. A poor model will have higher RSS, whereas a good model will 
have less difference between the observed and the predicted values. In other words, the observed value will lie closer to the regression line.

In addition to the model-fit statistics, R-squared indicates what percentage of variation in the dependent variable is explained by all the independent variables present in the model. However, R-squared has a tendency to report higher values when additional variables are added to the model, thus falsely representing a higher coefficient of determination. This can be avoided by reporting the value of "adjusted R-squared" in addition to R-squared. The adjusted R-squared cancels the effect of non-influential variables in the model. The difference between R-squared and adjusted R-squared can be used to see if the model is bloated with unnecessary variables.

The usefulness of OLS regression can be extended by using dummy variables, appropriately coded to group explanatory variables by type, year, geography, or any other common characteristic. A weakness of this method is its limited capacity to handle extreme outliers and a possible erroneous estimation of non-linear relationships. OLS regression results tend to be influenced by the presence of extreme outliers in the data; however, with careful analysis of the data, this can be avoided. The issue of non-linearity affects OLS regression as well as any general linear regression method. Such flexibility in handling data issues - the simplicity of the method to identify model-fit indices and variable coefficients — render this method appropriate for the type of analysis that this researcher intends to pursue. 


\section{Models}

Initially, two models were proposed to answer the questions posed by the hypotheses. Models 1 and 2 are the models of Mean Assessed Values for a given year and these same values over time. These models contain 13 predictors.

\section{Model 1}

Dependent variables: Mean Assessed Value 2000

Mean Assessed Value 2006

Mean Assessed Value 2008

Mean Assessed Value 2010

Test variable: $\quad$ Section 8 units per 1000 persons

Independent variables: $\quad$ Percent of vacant units 2000

Population 2000

Percent of non-white residents 2000

Miles to nearest superfund site

Inside the inner beltway (dummy)

Outside the outer beltway (dummy)

Tree density

Percent of rental units 2000

Total crimes per 100,000 residents 2004

Median housing age 2000

Model 2

Dependent variables: Mean Assessed Value percent change 2000-2006

Mean Assessed Value percent change 2006-2010 
Test variable: $\quad$ Section 8 units per 1000 persons

Independent variables: $\quad$ Percent of vacant units 2000

Population 2000

Percent of non-white residents 2000

Miles to nearest superfund site

Inside the inner beltway (dummy)

Outside the outer beltway (dummy)

Tree density

Percent of rental units 2000

Total crimes per 100,000 residents 2004

Median housing age 2000

After completing these regressions, the idea of performing a split regression to assist in the determination of the magnitude of the results was evaluated. A split regression of the lowest and highest densities of Section 8 housing, was used for each of the four years. This was an exact split of the data set and both the lowest $50^{\text {th }}$ percentile and the highest $50^{\text {th }}$ percentile were evaluated.

A second split regression was performed; this split was of the highest and lowest Mean Assessed Values within the Census tracts. This regression was run to determine a relationship impacted by asset values.

The results of these regressions were not as expected, so after evaluating these results, another regression was performed to determine if the implementation of Section 8 housing in smaller doses would have a lesser effect on the surrounding community. 


\section{Variables and Measures}

This dissertation mainly relies on quantitative data. The data was gathered from several sources: 1) the US census 2000 and 2010 decennial census; 2) the Jefferson County Property Valuation Administration (JCPVA); 3) the Louisville Metro Police Department (LMPD); and, 4) the Louisville/Jefferson County Information Consortium (LOJIC) system.

Data for the test variable utilized in this study was collected from the Louisville Metro Housing Authority (LMHA) as it supplied the location data for Section 8 vouchers as a count at the census tract level.

The desire was to explain mean assessed values with the 11 independent variables identified above. The control variables have been accepted by mainstream research and identified as variables impacting housing values as a dependent variable. These variables within housing literature are generally identified as traditional predictors of how value may change. Following is more information on the dependent variables, independent variables and control variables.

\section{Dependent variables}

In model 1, Mean Assessed Value of properties measured over several years is the Dependent variable. The Mean Assessed Value (MAV) for four periods between 2000 and 2010 have been used. These values will be noted as MAV 2000, MAV 2006, MAV 2008, and MAV 2010. This value was determined from the Jefferson County Property Valuation Administration (JCPVA) by census tract and is available for the years 2000, 2006, 2008, and 2010. Assessed values were used for this study rather than figures 
calculated from recorded sales. Every sale results in a reassessment and there is a process to keep the information current in the study area. The Property Value Administrator (PVA) in Louisville Metro must follow the Commonwealth of Kentucky Revised Statute 134.385 which requires that all assessments should be at least $80 \%$ of the fair market value of a home. Properties are reassessed in Louisville at least every 4 to 5 years unless a sale occurs (Gilderbloom et al., 2012; Ambrosius et al., 2010).

In model 2, percent change in Mean Assessed Value between the years 2000 and 2006, and between the years 2006 and 2010 were calculated. The calculation for the years 2000 to 2006 is shown here:

$$
\text { [ ( MAV2006 - MAV2000 )/ MAV2000 ] x } 100
$$

\section{Independent / test variable}

The test variable in this study will be Section 8 Housing stock per 1000 residents within a given census tract. The Section 8 numbers were as collected from LMHA as a count, and the population was determined by using the 2000 US Census at the census tract level.

\section{Independent / Control variables}

There are many variables that have known impacts on mean housing values. Several of these control variables have been included in the model to assist in making the model more robust. Since they have relationships with mean housing values, these variables can be used to help the model. There are other variables that may impact housing values, but these were not included since did not improve the significance of the regression. These control variables have known impacts on the dependent variables and have been used 
extensively in mainstream research under both OLS and OLS split regression analysis (Friedland, 1983; Kelly \& Adhikari, 2013).

The control variables used are as follows:

- Percent of vacant units, 2000 census (ratio * 100)

- Population -2000 census

- Percentage of non-white residents in each census tract (ratio * 100)

o The percentage of non-white residents is calculated by removing all selfidentified as white from the population total and divide this number into the total number of residents in the census tract.

- Miles to the nearest Superfund site

o This is a measurement of the centroid of each census tract to the nearest EPA Superfund site.

- Housing units inside the inner beltway (I-264) as a dummy variable (1/0)

o Every housing unit inside the Watterson Expressway (Interstate 264) was given a value of 1 . All other housing units in the county were given a value of 0 .

o This information was obtained from JCPVA.

- Housing units outside the outer beltway (I-265) as a dummy variable (1/0)

o Every housing unit outside the Gene Snyder Freeway (Interstate 265) was given a value of 1 . All other housing units in the county were given a value of 0 .

o This information was obtained from JCPVA.

- Tree density per person in each census tract 
- Percentage of rental units in each census tract (ratio * 100)

o Number of rental units provided in the 2000 Census was divided by the total number of housing units and this total was multiplied by 100 to provide a percentage.

- Total crimes per 100,000 residents as measured in 2004

o Information provided by LMPD.

- Median housing age, 2000

These variables were chosen as they are material and significant when it comes to providing an estimate of housing value. Controlling for non-white residents is an accepted method when conducting neighborhood level examinations. Locations near identified superfund sites need to be controlled, since it is accepted that these locations have impact on housing values. Vacant units, tree density, rental units, and crime are all useful in the determination of Mean Assessed Value.

See Table 3.1 for a concise description of the dependent variables' sources, years, means and standard deviations. Table 3.2 provides the same information for the independent variables. 
Table 3.1 Description of Dependent Variables

\begin{tabular}{|c|c|c|c|}
\hline Measure & Year(s) & \multicolumn{2}{|c|}{ Std. Dev. } \\
\hline Mean Assessed Value JCPVA & 2000 & 88,594 & 49,071 \\
\hline Mean Assessed Value JCPVA & 2006 & 117,455 & 61,543 \\
\hline Mean Assessed Value JCPVA & 2008 & 125,925 & 66,533 \\
\hline Mean Assessed Value JCPVA & 2010 & 125,888 & 70,499 \\
\hline
\end{tabular}

Notes: JCPVA: Jefferson County Property Valuation Administrator 
Table 3.2 Description of Test and Independent Variables

\begin{tabular}{|c|c|c|c|c|}
\hline Measure & Source & Year(s) & Mean & Std. Dev. \\
\hline \multicolumn{5}{|l|}{$\underline{\text { Test Variable }}$} \\
\hline $\begin{array}{l}\text { Section } 8 \text { units } \\
\text { per } 1000 \text { persons }\end{array}$ & LMHA & $2000-2010$ & 14.3 & 15.5 \\
\hline \multicolumn{5}{|l|}{ Independent Variables } \\
\hline $\begin{array}{l}\text { Percent of vacant } \\
\text { units }\end{array}$ & US Census & $2000-2010$ & 6.4 & 4.0 \\
\hline Population & US Census & $2000-2010$ & 4,080 & 1,671 \\
\hline $\begin{array}{l}\text { Percent of } \\
\text { non-white residents }\end{array}$ & US Census & $2000-2010$ & 25.4 & 29.5 \\
\hline $\begin{array}{l}\text { Miles to nearest } \\
\text { superfund site }\end{array}$ & LOJIC & 2000 & 2.2 & 1.4 \\
\hline Tree density & LOJIC & 2000 & 1.2 & 0.9 \\
\hline $\begin{array}{l}\text { Percent of rental } \\
\qquad 21.7 \\
\text { units }\end{array}$ & JCPVA & 2000 & & 36.9 \\
\hline $\begin{array}{l}\text { Total crimes per } \\
100,000 \text { residents }\end{array}$ & LMPD & 2004 & 6.1 & 3.2 \\
\hline Median housing age & US Census & $2000-2010$ & 38.7 & 15.1 \\
\hline
\end{tabular}

Notes:: LMHA - Louisville Metro Housing Authority; US Census, 2000 Census; LOJIC - Louisville/Jefferson County Information Consortium; JCPVA: Jefferson County Property Valuation Administrator; LMPD -Louisville Metro Police Department. 


\section{Qualitative Survey}

To supplement the statistical results of the above analysis, a qualitative component was prepared via an online survey of members of the Louisville Apartment Association (LAA). The members of LAA were asked their opinions of housing values among properties in areas with Section 8 housing recipients.

Questions were asked about the desirability of Section 8 residents within a particular apartment community, based upon behavior characteristics and financial benefits. The questions included in the online survey explored opinions of landlords and apartment managers as to their beliefs related to the impact of Section 8 residents on surrounding property values. These questions were asked in various ways while changing the concentration of Section 8 residents in the questions. There were five answer choices, two choices that supported agreement with the concept, two choices that supported disagreement with the concept, and lastly a neutral or no opinion option.

The next series of questions explored opinions on the behavior of Section 8 residents in a community and whether the landlords and managers are content with having Section 8 residents based upon issues such as profitability, problems, or evictions. Demographic information was also collected as well as locational information on the properties. An open ended question was included to provide an avenue for the survey respondents to provide free form thoughts related to these issues that were explored.

The results of this survey may guide recommendations as to future housing policy both on the local level as well as the national level. 


\section{Conclusion}

With a defined research question, hypotheses, methodology, and specification of variables, the following chapters explore the impact of Section 8 housing on Mean Assessed Values by testing the hypotheses. 


\section{CHAPTER FOUR - STATISTICAL ANALYSIS}

There has been no shortage of opinions related to the question of how Section 8 housing affects surrounding property values. Unfortunately, most of the discussion has not been grounded in fact. This study responds to the shortage of facts by examining the relationships between Section 8 housing and nearby property values, focusing on whether relationships could occur by chance, Significance will be assigned when odds of a chance event are less than 5 percent. Maximum significance will reflect only a 0.1 percent chance that the relationship occurred by chance. This chapter provides the results of each individual regression, descriptive statistics, and applicable maps to enhance understanding of the analysis.

Using a standard regression model that predicts housing values, the unique key test variable Section 8 housing density per 1000 residents was isolated from the other independent variables identified in the literature review. The amount of variation explained by the models was strong, keeping all other independent variables constant. Adjusted R square values for the models ranged from a low of 0.356 to a high of 0.712 . Overall, the majority of the models yielded adjusted R squares of greater than 0.50 . In the area of significance of the control variables, some of the variables in the analysis did not provide significant relationships, defined as a probability less than 0.05 , in all of the models. However, it was determined that these variables should remain in the model to assess valuation as performed by the Property Value Administrator or by social scientists 
in evaluations of property values. While the control variables were not significant in all cases, they showed significance in the predicted direction of the given variable in many of the models.

There are a total of 170 Census tracts in the data set. A few of the tracts did not have all of the variables used in the regression, and this caused the overall $\mathrm{N}$ for the regressions to vary between 168 and 170 . When split regressions were run, the number of census tracts was the determining factor in the split. If a balanced split regression was run, referred to as a 50/50 regression, the number of census tracts in each split was either 84 or 85 depending on the data. The same type of ratios were used when performing a $75 / 25$ split regression.

Tolerance scores were calculated for all models as a test for any multicollinearity concerns (Appelbaum \& Dolny, 1991; Gilderbloom \& Appelbaum, 1992; Lewis-Beck, 1980, 1993). All tolerance scores exceeded a traditional cutoff value of 0.30 . In the original regressions, the variable 'Distance to the Central Business District (CBD)' was intended to be included in the analysis. The tolerance score for this variable was under 0.20 in every regression. Even though the distance to the CBD is a theoretically important predictor of Mean Assessed Values in a given community, given the potential for problems with the regressions, this variable was removed. The changes as a result of this revision to the regressions were minimal, and it was decided to proceed with the omission of this variable. 


\section{Analysis and Findings}

Model 1 - Mean Assessed Value for the years 2000, 2006, 2008, and 2010

Model 1 was the initial model run to determine that the data set was sound and would yield meaningful results. The regression results follow in Table 4.1.

In all four of the study years, there was a statistically significant relationship between Section 8 units per 1000 persons and mean assessed values. It is consistently shown that as the density of Section 8 residents increases within a given census tract, mean assessed values will decline.

If one looks at three variables — 'miles to the nearest superfund site', 'percent of rental units', and 'total crimes per 1000 residents' — results show that mean assessed values react to each of these variables, as would be expected in the real estate world. As the number of miles to the nearest superfund site increases, the mean assessed values increase. It certainly makes sense in the converse; as a Census tract moves closer to a superfund site, housing valuations will decrease. Likewise, with rental units and crime; as either of these variables increase, assessed values decrease. For all of these examples referenced, the results are significant in all four years of the data set to a probability of less than 0.01 .

Further evaluation related to the intercept value also confirms that the data reflects the reality observed during this time period. The intercept or the starting point for mean assessed values is in expected range in the year 2000. This value increases in the years 2006 and 2008, yet in 2010 there is a decrease in intercept value which reflects the impact of the housing recession that occurred during that time frame (Gilderbloom et al., 2012). 
The descriptive for the initial regression model were provided earlier in

Tables 3.1 and 3.2, so that are not repeated here. Overall, the result shows that Section 8 housing density increases cause nearby assessed values to decline. Given the sensitivity of this issue in the public eye, further regressions needed to be explored. 
Table 4.1 Model 1 - Regression Models Summary - Mean Assessed Values

\begin{tabular}{|c|c|c|c|c|c|c|c|c|}
\hline \multirow[t]{2}{*}{ Dependent Variable } & \multicolumn{2}{|c|}{$\begin{array}{c}\text { Mean Assessed Value (MAV) } \\
\text { MAV-2000 }\end{array}$} & \multicolumn{2}{|c|}{$\begin{array}{c}\text { Mean Assessed Value (MAV) } \\
\text { MAV-2006 }\end{array}$} & \multicolumn{2}{|c|}{$\begin{array}{c}\text { Mean Assessed Value (MAV) } \\
\text { MAV-2008 }\end{array}$} & \multicolumn{2}{|c|}{$\begin{array}{c}\text { Mean Assessed Value (MAV) } \\
\text { MAV-2010 }\end{array}$} \\
\hline & $\begin{array}{c}\text { Unstandardized } \\
\text { Coefficient } \\
\text { B }\end{array}$ & $\begin{array}{c}\text { Standardized } \\
\text { beta }\end{array}$ & $\begin{array}{c}\text { Unstandardized } \\
\text { Coefficient } \\
\text { B }\end{array}$ & $\begin{array}{c}\text { Standardized } \\
\text { beta }\end{array}$ & \begin{tabular}{|} 
Unstandardized \\
Coefficient \\
B
\end{tabular} & $\begin{array}{c}\text { Standardized } \\
\text { beta }\end{array}$ & $\begin{array}{c}\text { Unstandardized } \\
\text { Coefficient } \\
\text { B }\end{array}$ & $\begin{array}{c}\text { Standardized } \\
\text { beta }\end{array}$ \\
\hline $\begin{array}{l}\text { Section } 8 \text { units per } \\
1000 \text { persons }\end{array}$ & $-1159.323^{* * *}$ & $-0.366^{* * *}$ & $-1648.79 * * *$ & $-0.418^{* * *}$ & $-2050.864 * * *$ & $-0.48^{* * *}$ & $-2109.276^{* * *}$ & $-0.465^{* * *}$ \\
\hline $\begin{array}{c}\text { Percent of vacant } \\
\text { units, } 2000 \\
\text { (ratio*100) }\end{array}$ & $2930.537 * * *$ & $0.24 * * *$ & $4212.29 * * *$ & $0.268 * * *$ & $4910.479 * * *$ & $0.299 * * *$ & $5096.513^{* * *}$ & $0.292 * * *$ \\
\hline Population 2000 & 2.598 & 0.088 & 2.657 & 0.072 & 1.881 & 0.047 & 2.363 & 0.056 \\
\hline $\begin{array}{l}\text { Percent of non-white } \\
\text { residents, } 2000 \\
(\text { ratio*100) }\end{array}$ & -199.241 & -0.12 & -141.95 & -0.067 & -156.129 & -0.068 & -235.152 & -0.097 \\
\hline $\begin{array}{l}\text { Miles to nearest } \\
\text { superfund site }\end{array}$ & $8310.471^{* * *}$ & $0.23 * * *$ & $10204.163 * * *$ & $0.225^{* * *}$ & $9643.919 * *$ & $0.196^{* *}$ & $11362.62 * * *$ & $0.218^{* * *}$ \\
\hline $\begin{array}{c}\text { Inside the inner } \\
\text { beltway (Watterson, I- } \\
\text { 264) dummy variable } \\
(1 / 0)\end{array}$ & $31840.36^{* * *}$ & $0.319 * * *$ & $42754.379 * * *$ & $0.34 * * *$ & $48781.553 * * *$ & $0.36^{* * *}$ & $50961.828^{* * *}$ & $0.355^{* * *}$ \\
\hline $\begin{array}{c}\text { Outside the outer } \\
\text { beltway (Gene } \\
\text { Snyder, I-265) } \\
\text { dummy variable }(1 / 0)\end{array}$ & -16046.318 & -0.098 & -19984.823 & -0.098 & -23004.162 & -0.105 & -23400.541 & -0.1 \\
\hline $\begin{array}{c}\text { Tree density (per } \\
\text { person) }\end{array}$ & 5150.03 & 0.091 & $8893.371^{*}$ & $0.126^{*}$ & $11667.275^{* *}$ & $0.153^{* *}$ & $11148.177^{*}$ & $0.137^{*}$ \\
\hline $\begin{array}{l}\text { Percent of rental } \\
\text { units, } 2000 \\
\text { (ratio*100) }\end{array}$ & $-500.871 * * *$ & $-0.221 * * *$ & $-594.842 * *$ & $-0.2 * *$ & $-572.879 * *$ & $-0.183 * *$ & $-537.592 *$ & $-0.162^{*}$ \\
\hline $\begin{array}{c}\text { Total crimes per } \\
\text { 100,000 residents, } \\
\text { 2004, by LMPD } \\
\text { district }\end{array}$ & $-4307.034 * * *$ & $-0.283^{* * *}$ & $-4474.048 * *$ & $-0.22 * *$ & $-4332.15^{* *}$ & $-0.204 * *$ & $-4618.418^{* *}$ & $-0.205^{* *}$ \\
\hline $\begin{array}{c}\text { Median Housing Age, } \\
2000\end{array}$ & $-591.804 *$ & $-0.182^{*}$ & $-962.234 * *$ & $-0.237 * *$ & $-1050.706^{* *}$ & $-0.239 * *$ & $-1067.481 * *$ & $-0.229 * *$ \\
\hline Intercept & 112600 & *** & 144055 & $5^{* * *}$ & 155109 & $9^{* * *}$ & 15179 & $0 * * *$ \\
\hline R Square & .68 & & .66 & & .66 & & .66 & \\
\hline Adjusted R Square & .66 & & .637 & & .64 & & .64 & \\
\hline $\mathrm{N}$ & 170 & & 168 & & 168 & & 16 & \\
\hline Significance & $.000^{*}$ & & $.000^{*}$ & & $.000^{*}$ & & .000 & \\
\hline Notes: $*=p \leq .05$ & $* *=p \leq .01 ; * *$ & $*=p \leq .001$ & & & & & & \\
\hline
\end{tabular}




\section{Model 2 - Change in Mean Assessed Value over time}

Do good economic times or bad economic times have an increased effect on Section 8 density and the mean assessed value relationship? This question can arise related to the change in economic position over the time period of the study.

With that in mind, the change in mean assessed value over time was studied. One case was the change from 2000 to 2006, a period of good housing value growth. The other case was the change from 2008 to 2010 , a period of depressed housing growth. The absolute change was calculated for the years in question. The regression results and the variable descriptive follow.

This case confirms the previous result seen in Table 4.1 that increases in Section 8 housing density statistically cause decreases in mean assessed values. The result confirms that during a period of economic growth or during a period of economic malaise, the relationship between Section 8 housing density and mean assessed valuations are both significant.

General observations on this model are that the adjusted R square for the 2000 to 2006 time frame yields the lowest result of all regressions in this dissertation. The control variables have the least significance as well, a result expected with the low R square. An important note relates to the identified significance of crime in the 2008 to 2010 time frame. This result is immaterial as the crime data only reflects the year 2004. This is a limitation of the dataset, but crime was included in all models due to its general importance related to Section 8 and neighborhood values. 
The conclusion at this point is that the relative strength or weakness of the economy does not have an impact on the initial determination of cause and effect of Section 8 density on assessed valuations. Whether good economic times or bad, the effect of Section 8 density on mean assessed values does not change. 
Table 4.2 Model 2 - Change in Mean Assessed Value over time

\begin{tabular}{|c|c|c|c|c|}
\hline \multirow[t]{2}{*}{ Dependent Variable } & \multicolumn{2}{|c|}{$\begin{array}{c}\text { Mean Assessed Value (MAV) Change } \\
\text { MAV-2000 to MAV } 2006\end{array}$} & \multicolumn{2}{|c|}{$\begin{array}{c}\text { Mean Assessed Value (MAV) Change } \\
\text { MAV-2008 to MAV } 2010\end{array}$} \\
\hline & $\begin{array}{c}\text { Unstandardized } \\
\text { Coefficient } \\
\text { B } \\
\end{array}$ & $\begin{array}{l}\text { Standardized } \\
\text { beta }\end{array}$ & $\begin{array}{l}\text { Unstandardized } \\
\text { Coefficient } \\
\text { B } \\
\end{array}$ & $\begin{array}{l}\text { Standardized } \\
\text { beta }\end{array}$ \\
\hline $\begin{array}{l}\text { Section } 8 \text { units per } 1000 \\
\text { persons }\end{array}$ & $-434.718^{* * *}$ & $-0.405^{* * *}$ & $-267.477 * * *$ & $-0.372 * * *$ \\
\hline $\begin{array}{l}\text { Percent of vacant units, } 2000 \\
\text { (ratio*100) }\end{array}$ & $1050.359 *$ & $0.245^{*}$ & $455.971 *$ & $0.159 *$ \\
\hline Population 2000 & 0.136 & 0.014 & -0.056 & -0.008 \\
\hline $\begin{array}{l}\text { Percent of non-white } \\
\text { residents, } 2000 \text { (ratio*100) }\end{array}$ & 52.368 & 0.091 & $-138.447 * * *$ & $-0.358 * * *$ \\
\hline $\begin{array}{l}\text { Miles to nearest superfund } \\
\text { site }\end{array}$ & 1853.433 & 0.15 & $1063.634^{*}$ & $0.129 *$ \\
\hline $\begin{array}{l}\text { Inside the inner beltway } \\
\text { (Watterson, I-264) dummy } \\
\text { variable }(1 / 0)\end{array}$ & $11377.116^{* * *}$ & $0.333 * * *$ & $9040.476^{* * *}$ & $0.395 * * *$ \\
\hline $\begin{array}{l}\text { Outside the outer beltway } \\
\text { (Gene Snyder, I-265) dummy } \\
\text { variable }(1 / 0)\end{array}$ & -3480.752 & -0.063 & -2210.588 & -0.06 \\
\hline Tree density (per person) & $3269.049 *$ & $0.17 *$ & 1003.884 & 0.078 \\
\hline $\begin{array}{l}\text { Percent of rental units, } 2000 \\
\text { (ratio*100) }\end{array}$ & -105.622 & -0.131 & 13.148 & 0.024 \\
\hline $\begin{array}{l}\text { Total crimes per 100,000 } \\
\text { residents, 2004, by LMPD } \\
\text { district }\end{array}$ & -417.136 & -0.075 & $-1065.702 * * *$ & $-0.288 * * *$ \\
\hline Median Housing Age, 2000 & $-357.778 * *$ & $-0.324 * *$ & -44.102 & -0.06 \\
\hline Intercept & & & & \\
\hline R Square & & & & \\
\hline Adjusted R Square & & & & \\
\hline $\mathrm{N}$ & & & & \\
\hline Significance & & & & \\
\hline Notes: $*=p \leq .05 ; * *=p \leq .01$ & $* * *=p \leq .001$ & & & \\
\hline
\end{tabular}




\section{Table 4.3 Descriptives for Total Dataset}

\begin{tabular}{|c|c|c|c|c|c|c|c|c|c|}
\hline & $\underline{\mathrm{IV} / \mathrm{DV}}$ & Year & $\underline{\text { SOURCE }}$ & MEASURE & $\underline{\text { MIN }}$ & $\underline{\text { MAX }}$ & $\underline{\text { MEAN }}$ & $\underline{\text { STD DEV }}$ & $\underline{\mathrm{N}}$ \\
\hline Section 8 Units per 1000 persons & IV & $2000-2010$ & LMHA & \# & 0 & 73.2 & 14.3 & 15.5 & 170 \\
\hline Percentage of Vacant Units & IV & 2000 & Census & $\%$ & 1.8 & 20.0 & 6.4 & 4.0 & 170 \\
\hline Population & IV & 2000 & Census & \# & 1355 & 10267 & 4080 & 1671 & 170 \\
\hline Percentage of Non-White Residents & IV & 2000 & Census & $\%$ & 1.4 & 99.4 & 25.4 & 29.5 & 170 \\
\hline Miles to Nearest Superfund Site & IV & 2000 & LOJIC & mi. & 0.1 & 7.6 & 2.2 & 1.4 & 170 \\
\hline Tree Density per Person & IV & 2000 & LOJIC & \# & 0.2 & 6.0 & 1.2 & 0.9 & 170 \\
\hline Percentage of Rental Units & IV & 2000 & JCPVA & $\%$ & 3.0 & 99.3 & 36.9 & 21.7 & 170 \\
\hline Total Number of Crimes per 100,000 & IV & 2004 & LMPD & \# & 3.4 & 16.6 & 6.1 & 3.2 & 170 \\
\hline Median Housing Age & IV & 2000 & Census & \# & 2 & 60 & 38.7 & 15.1 & 170 \\
\hline Median Assessed Housing Value - 2000 & DV & 2000 & JCPVA & $\$$ & 4105 & 255000 & 88594 & 49071 & 170 \\
\hline Median Assessed Housing Value - 2006 & DV & 2006 & JCPVA & $\$$ & 8820 & 333765 & 117455 & 61543 & 168 \\
\hline Median Assessed Housing Value - 2008 & DV & 2008 & JCPVA & $\$$ & 32030 & 366070 & 125925 & 66533 & 168 \\
\hline Median Assessed Housing Value - 2010 & DV & 2010 & JCPVA & $\$$ & 26375 & 368870 & 125888 & 70499 & 169 \\
\hline
\end{tabular}

Notes: LMHA - Louisville Metro Housing Authority; US Census, 2000 Census; LOJIC - Louisville/Jefferson County Information Consortium; JCPVA: Jefferson County Property Valuation Administrator; LMPD -Louisville Metro Police Department. 
Split Regression Section 8 density, most dense/least dense $-50 / 50$

Given the result that the strength of the economy does not change the net effect of assessed values related to Section 8 housing density, the next step was to evaluate how the relationship may change as Section 8 densities change within each Census tract. A split regression was used. The data shows, in the 170 census tracts, that the Section 8 density per 1000 residents varied from zero to 73.2 units per 1000 residents. If the median is taken in terms of Census tracts, there will be two groups of 85 tracts. The lower half of these tracts will have a Section 8 density per 1000 residents of between 0 and 8.1 units. The denser half of the Census tracts will have a Section 8 density per 1000 residents of between 8.4 and 73.2 units. The split regression will use the 85 census tracts in either the lowest 50 percentile or the highest 50 percentile as the case may be.

One would expect that the impact within the more dense Section 8 housing should have a more significant relationship to assessed valuations. If Section 8 housing has an influence on values, as was shown in Model 1, it seems logical that a greater density there would have greater impact.

The tables that follow show the results. Table 4.4 and Table 4.5 show the most dense $50^{\text {th }}$ percentile, and Table 4.6 and Table 4.7 show the least dense $50^{\text {th }}$ percentile. The results were not as expected. While both models showed significant results, the adjusted R square and its relationship with Section 8 density were better in the model of the least dense $50^{\text {th }}$ percentile. The absolute magnitude of the impact was also greater. Even with the lower densities, the results were significant to a probability of less than or 
equal to .001 for all four years of the study. The regression on the least dense Census tracts is considerably more robust in the most important measurement techniques.

Given this result, a possible explanation is that the least dense Section 8 housing locations are the areas with higher mean assessed values, then it can be inferred that these same Census tracts have higher average incomes. With higher incomes, the residents have a greater ability to 'vote with their feet' and to move to a new location within the city or even outside of the city. If the desire is great enough to relocate, then individuals may sell at a below market price, thus driving down the assessed values in the neighborhood.

A map of the 170 Louisville Census tracts follows. This shows the location of the most and least dense Section 8 Census tracts around Louisville. The higher Section 8 density is predominantly west and northwest of the CBD. There is also a dense area in the center of the city that is a historically minority location. The east and south central portions of the city are the areas of lower Section 8 density. The white areas on the map represent areas with either no Section 8 units or there is no information available. 
Table 4.4 Model 3A - Split Regression Section 8 density - $50 \%$ most dense

\begin{tabular}{|c|c|c|c|c|c|c|c|c|}
\hline \multirow[t]{2}{*}{ Dependent Variable } & \multicolumn{2}{|c|}{$\begin{array}{l}\text { Mean Assessed Value (MAV) } \\
\text { Split (highest } 50 \text { percentile } \\
\text { Section } 8 \text { density) MAV-2000 }\end{array}$} & \multicolumn{2}{|c|}{$\begin{array}{l}\text { Mean Assessed Value (MAV) } \\
\text { Split (highest } 50 \text { percentile } \\
\text { Section } 8 \text { density) MAV-2006 }\end{array}$} & \multicolumn{2}{|c|}{$\begin{array}{l}\text { Mean Assessed Value (MAV) } \\
\text { Split (highest } 50 \text { percentile } \\
\text { Section } 8 \text { density MAV-2008 }\end{array}$} & \multicolumn{2}{|c|}{$\begin{array}{l}\text { Mean Assessed Value (MAV) } \\
\text { Split (highest } 50 \text { percentile } \\
\text { Section } 8 \text { density) MAV-2010 }\end{array}$} \\
\hline & $\begin{array}{l}\text { Unstandardized } \\
\text { Coefficient } \\
\text { B }\end{array}$ & $\begin{array}{l}\text { Standardized } \\
\text { beta }\end{array}$ & $\begin{array}{l}\text { Unstandardized } \\
\text { Coefficient } \\
\text { B }\end{array}$ & $\begin{array}{l}\text { Standardized } \\
\text { beta }\end{array}$ & $\begin{array}{l}\text { Unstandardized } \\
\text { Coefficient } \\
\text { B }\end{array}$ & $\begin{array}{c}\text { Standardized } \\
\text { beta }\end{array}$ & $\begin{array}{l}\text { Unstandardized } \\
\text { Coefficient } \\
\text { B }\end{array}$ & $\begin{array}{l}\text { Standardized } \\
\text { beta }\end{array}$ \\
\hline $\begin{array}{l}\text { Section } 8 \text { units per } \\
1000 \text { persons }\end{array}$ & -338.442 & -0.176 & $-806.406^{* *}$ & $-0.359^{* *}$ & $-1232.984^{* * *}$ & $-0.461^{* * * *}$ & $-1284.727^{* * *}$ & $-0.447^{* * *}$ \\
\hline $\begin{array}{l}\text { Percent of vacant units, } \\
2000 \text { (ratio*100) }\end{array}$ & -959.765 & -0.154 & -366.416 & -0.048 & 521.474 & 0.06 & 494.829 & 0.053 \\
\hline Population 2000 & 1.619 & 0.091 & 0.647 & 0.031 & -0.671 & -0.027 & -0.532 & -0.02 \\
\hline $\begin{array}{l}\text { Percent of non-white } \\
\text { residents, 2000 } \\
\text { (ratio*100) }\end{array}$ & $-220.954^{* *}$ & $-0.262^{* *}$ & -153.689 & -0.154 & -109.114 & -0.092 & -193.641 & -0.152 \\
\hline $\begin{array}{l}\text { Miles to nearest } \\
\text { superfund site }\end{array}$ & $6117.817^{* *}$ & $0.244^{* *}$ & $6786.337^{*}$ & $0.232^{*}$ & $7918.532^{*}$ & $0.227^{*}$ & $8226.401^{*}$ & $0.22 *$ \\
\hline $\begin{array}{l}\text { Inside the inner } \\
\text { beltway (Watterson, I- } \\
\text { 264) dummy variable } \\
(1 / 0)\end{array}$ & $16476.302^{* *}$ & $0.29^{* *}$ & $20338.778^{* *}$ & $0.305^{* *}$ & $23628.678^{*}$ & $0.299^{*}$ & $23414.277^{*}$ & $0.275^{*}$ \\
\hline $\begin{array}{c}\text { Outside the outer } \\
\text { beltway (Gene Snyder, } \\
\text { I-265) dummy variable } \\
(1 / 0)\end{array}$ & -9340.78 & -0.061 & -8126.858 & -0.046 & -7195.23 & -0.034 & -7059.988 & -0.031 \\
\hline $\begin{array}{l}\text { Tree density (per } \\
\text { person) }\end{array}$ & $9435.578^{*}$ & $0.199^{*}$ & 10052.541 & 0.181 & $16883.143^{*}$ & $0.257^{*}$ & $17393.899^{*}$ & $0.246^{*}$ \\
\hline $\begin{array}{l}\text { Percent of rental units, } \\
2000 \text { (ratio* } 100 \text { ) }\end{array}$ & 54.699 & 0.039 & 193.428 & 0.109 & 322.189 & 0.159 & 413.09 & 0.19 \\
\hline $\begin{array}{c}\text { Total crimes per } \\
100,000 \text { residents, } \\
2004 \text {, by LMPD } \\
\text { district }\end{array}$ & $-3063.985^{* * *}$ & $-0.407^{* * *}$ & $-2909.879^{* *}$ & $-0.309^{* *}$ & -2029.4 & -0.188 & -2213.242 & -0.191 \\
\hline $\begin{array}{c}\text { Median Housing Age, } \\
2000\end{array}$ & 82.787 & 0.036 & -278.375 & -0.104 & -486.413 & -0.152 & -543.694 & -0.158 \\
\hline Intercept & 69149 & & 10435 & 1**** & 103967 & $* * *$ & 10502 & $3 * * *$ \\
\hline $\mathrm{R}$ Square & .70 & & .60 & & .54 & & .58 & \\
\hline Adjusted R Square & .65 & & .54 & & .47. & & .52 & \\
\hline $\mathrm{N}$ & 85 & & 83 & & 84 & & 84 & \\
\hline Significance & $.000^{*}$ & & $.000^{\circ}$ & & $.000^{*}$ & & $.000^{\circ}$ & \\
\hline
\end{tabular}

Notes: $* p \leq .05 ; *=p \leq .01 ; \cdots * p \leq .001$ 
Table 4.5 Descriptives for Section 8 Density $-50 \%$ most dense

\begin{tabular}{|c|c|c|c|c|c|c|c|c|c|}
\hline & $\underline{\mathrm{IV} / \mathrm{DV}}$ & Year & $\underline{\text { SOURCE }}$ & MEASURE & $\underline{\mathrm{MIN}}$ & MAX & MEAN & STD DEV & $\underline{N}$ \\
\hline Section 8 Units per 1000 persons & IV & $2000-2010$ & LMHA & $\#$ & 8.4 & 73.2 & 25.6 & 14.8 & 85 \\
\hline Percentage of Vacant Units & IV & 2000 & Census & $\%$ & 2.4 & 20.0 & 7.9 & 4.6 & 85 \\
\hline Population & IV & 2000 & Census & \# & 1355 & 9272 & 3801 & 1604 & 85 \\
\hline Percentage of Non-White Residents & IV & 2000 & Census & $\%$ & 3.1 & 99.4 & 41.0 & 33.8 & 85 \\
\hline Miles to Nearest Superfund Site & IV & 2000 & LOJIC & mi. & 0.2 & 4.9 & 1.7 & 1.1 & 85 \\
\hline Tree Density per Person & IV & 2000 & LOJIC & $\#$ & 0.2 & 4.2 & 0.9 & 0.6 & 85 \\
\hline Percentage of Rental Units & IV & 2000 & JCPVA & $\%$ & 12.7 & 99.3 & 44.5 & 20.4 & 85 \\
\hline Total Number of Crimes per 100,000 & IV & 2004 & LMPD & \# & 3.4 & 16.6 & 7.6 & 3.8 & 85 \\
\hline Median Housing Age & IV & 2000 & Census & $\#$ & 2 & 60 & 44.1 & 12.3 & 85 \\
\hline & & & & & & & & & \\
\hline Median Assessed Housing Value - 2000 & DV & 2000 & JCPVA & $\$$ & 4105 & 179000 & 59163 & 28512 & 85 \\
\hline Median Assessed Housing Value - 2006 & DV & 2006 & JCPVA & $\$$ & 8820 & 227060 & 81360 & 33477 & 83 \\
\hline Median Assessed Housing Value - 2008 & DV & 2008 & JCPVA & $\$$ & 32030 & 257460 & 86789 & 39708 & 84 \\
\hline Median Assessed Housing Value - 2010 & DV & 2010 & JCPVA & $\$$ & 26375 & 262235 & 84389 & 42702 & 84 \\
\hline \multicolumn{10}{|c|}{ Notes: LMHA - Louisville Metro Housing Authority; US Census, 2000 Census; LOJIC - Louisville/Jefferson County Information Consortium } \\
\hline JCPVA: Jefferson County Property & lation $\mathrm{A}$ & inistrator; L & D -Louisv & Metro Polic & Departn & & & & \\
\hline
\end{tabular}


Table 4.6 Model 3B - Split Regression Section 8 density - 50\% least dense

\begin{tabular}{|c|c|c|c|c|c|c|c|c|}
\hline \multirow[t]{2}{*}{ Dependent Variable } & \multicolumn{2}{|c|}{$\begin{array}{l}\text { Mean Assessed Value (MAV) } \\
\text { Split (lowest } 50 \text { percentile } \\
\text { Section } 8 \text { density) MAV-2000 }\end{array}$} & \multicolumn{2}{|c|}{$\begin{array}{l}\text { Mean Assessed Value (MAV) } \\
\text { Split (lowest } 50 \text { percentile } \\
\text { Section } 8 \text { density) MAV-2006 }\end{array}$} & \multicolumn{2}{|c|}{$\begin{array}{l}\text { Mean Assessed Value (MAV) } \\
\text { Split (lowest } 50 \text { percentile } \\
\text { Section } 8 \text { density) MAV-2008 }\end{array}$} & \multicolumn{2}{|c|}{$\begin{array}{l}\text { Mean Assessed Value (MAV) } \\
\text { Split (lowest } 50 \text { percentile } \\
\text { Section } 8 \text { density) MAV-2010 }\end{array}$} \\
\hline & $\begin{array}{l}\text { Unstandardized } \\
\text { Coefficient } \\
\text { B }\end{array}$ & $\begin{array}{c}\text { Standardized } \\
\text { beta }\end{array}$ & $\begin{array}{c}\text { Unstandardized } \\
\text { Coefficient } \\
\text { B }\end{array}$ & $\begin{array}{c}\text { Standardized } \\
\text { beta }\end{array}$ & $\begin{array}{c}\text { Unstandardized } \\
\text { Coefficient } \\
\text { B }\end{array}$ & $\begin{array}{c}\text { Standardized } \\
\text { beta }\end{array}$ & \begin{tabular}{|} 
Unstandardized \\
Coefficient \\
B
\end{tabular} & $\begin{array}{c}\text { Standardized } \\
\text { beta }\end{array}$ \\
\hline $\begin{array}{l}\text { Section } 8 \text { units per } \\
1000 \text { persons }\end{array}$ & $-7477.445^{* * *}$ & $-0.39 * * *$ & $-9374.258^{* * *}$ & $-0.374 * * *$ & $-10656.935^{* * *}$ & $-0.409 * * *$ & $-10516.246^{* * *}$ & $-0.382 * * *$ \\
\hline $\begin{array}{c}\text { Percent of vacant } \\
\text { units, } 2000 \\
\text { (ratio*100) }\end{array}$ & $5730.867 * * *$ & $0.325 * * *$ & $6560.947 * *$ & $0.285^{* *}$ & $6725.572 * *$ & $0.281^{* *}$ & $7429.395^{* * *}$ & $0.293 * * *$ \\
\hline Population 2000 & 3.701 & 0.132 & 5.112 & 0.139 & 4.1 & 0.107 & 5.181 & 0.128 \\
\hline $\begin{array}{l}\text { Percent of non-white } \\
\text { residents, } 2000 \\
(\text { ratio*100) }\end{array}$ & 429.653 & 0.095 & 678.817 & 0.115 & 431.647 & 0.07 & 509.008 & 0.078 \\
\hline $\begin{array}{l}\text { Miles to nearest } \\
\text { superfund site }\end{array}$ & $8830.921 * *$ & $0.249^{* *}$ & $10983.854 *$ & $0.237^{*}$ & 8542.059 & 0.175 & $11352.591^{*}$ & $0.223^{*}$ \\
\hline $\begin{array}{c}\text { Inside the inner } \\
\text { beltway (Watterson, I- } \\
\text { 264) dummy variable } \\
(1 / 0)\end{array}$ & 19072.767 & 0.187 & 31022.561 & 0.233 & $35332.78^{*}$ & $0.255^{*}$ & $39422.97 *$ & $0.269^{*}$ \\
\hline $\begin{array}{c}\text { Outside the outer } \\
\text { beltway (Gene } \\
\text { Snyder, I-265) } \\
\text { dummy variable (1/0) }\end{array}$ & -13380.751 & -0.105 & -18417.508 & -0.11 & -17745.012 & -0.102 & -18450.776 & -0.1 \\
\hline $\begin{array}{l}\text { Tree density (per } \\
\text { person) }\end{array}$ & 1786.744 & 0.038 & 5312.23 & 0.086 & 6693.384 & 0.105 & 5716.889 & 0.084 \\
\hline $\begin{array}{l}\text { Percent of rental } \\
\text { units, } 2000 \\
\text { (ratio*100) }\end{array}$ & $-907.817 * *$ & $-0.373 * *$ & $-1144.83^{* *}$ & $-0.36^{* *}$ & $-1089.694 * *$ & $-0.33 * *$ & $-1187.488 * *$ & $-0.339 * *$ \\
\hline $\begin{array}{c}\text { Total crimes per } \\
\text { 100,000 residents, } \\
\text { 2004, by LMPD } \\
\text { district }\end{array}$ & $-8803.276^{*}$ & $-0.242 *$ & $-9843.949^{*}$ & $-0.207^{*}$ & $-11319.726^{*}$ & $-0.23^{*}$ & $-12022.054^{*}$ & $-0.23^{*}$ \\
\hline $\begin{array}{c}\text { Median Housing Age, } \\
2000\end{array}$ & 8.937 & 0.003 & -250.227 & -0.063 & -252.724 & -0.061 & -161.406 & -0.037 \\
\hline Intercept & 12601 & $3 * * *$ & 159768 & $8 * * *$ & 190329 & $9 * * *$ & 178315 & $5 * * *$ \\
\hline R Square & .67 & & .65 & & .67 & & .66 & \\
\hline Adjusted R Square & .62 & & .60 & & .63 & & .613 & \\
\hline $\mathrm{N}$ & 85 & & 85 & & 84 & & 85 & \\
\hline Significance & $.000^{\circ}$ & & $.000 *$ & & $.000^{*}$ & & $.000 *$ & \\
\hline
\end{tabular}


Table 4.7 Descriptives for Section 8 Density $-50 \%$ least dense

\begin{tabular}{|c|c|c|c|c|c|c|c|c|c|}
\hline & $\underline{\mathrm{IV} / \mathrm{DV}}$ & Year & $\underline{\text { SOURCE }}$ & MEASURE & $\underline{\mathrm{MIN}}$ & $\underline{\mathrm{MAX}}$ & MEAN & STD DEV & $\underline{\mathrm{N}}$ \\
\hline Section 8 Units per 1000 persons & IV & $2000-2010$ & LMHA & $\#$ & 0 & 8.1 & 3.0 & 2.5 & 85 \\
\hline Percentage of Vacant Units & IV & 2000 & Census & $\%$ & 1.8 & 17.7 & 5.0 & 2.7 & 85 \\
\hline Population & IV & 2000 & Census & \# & 1635 & 10267 & 4358 & 1698 & 85 \\
\hline Percentage of Non-White Residents & IV & 2000 & Census & $\%$ & 1.4 & 80.7 & 9.7 & 10.5 & 85 \\
\hline Miles to Nearest Superfund Site & IV & 2000 & LOJIC & mi. & 0.1 & 7.6 & 2.7 & 1.3 & 85 \\
\hline Tree Density per Person & IV & 2000 & LOJIC & $\#$ & 0.4 & 6.0 & 1.4 & 1.0 & 85 \\
\hline Percentage of Rental Units & IV & 2000 & JCPVA & $\%$ & 3.0 & 93.9 & 27.6 & 19.6 & 85 \\
\hline Total Number of Crimes per 100,000 & IV & 2004 & LMPD & \# & 3.4 & 9.7 & 4.6 & 1.3 & 85 \\
\hline Median Housing Age & IV & 2000 & Census & $\#$ & 4 & 60 & 33.4 & 15.7 & 85 \\
\hline & & & & & & & & & \\
\hline Median Assessed Housing Value - 2000 & DV & 2000 & JCPVA & $\$$ & 27535 & 255510 & 118025 & 47735 & 85 \\
\hline Median Assessed Housing Value - 2006 & DV & 2006 & JCPVA & $\$$ & 8820 & 333765 & 152701 & 62383 & 85 \\
\hline Median Assessed Housing Value - 2008 & DV & 2008 & JCPVA & $\$$ & 37480 & 366070 & 165061 & 65037 & 84 \\
\hline Median Assessed Housing Value - 2010 & DV & 2010 & JCPVA & $\$$ & 29560 & 368870 & 166899 & 68661 & 85 \\
\hline \multicolumn{10}{|c|}{ Notes: LMHA - Louisville Metro Housing Authority; US Census, 2000 Census; LOJIC - Louisville/Jefferson County Information Consortium; } \\
\hline JCPVA: Jefferson County Property & lation $\mathrm{A}$ & inistrator; L & D -Louisv & Metro Polic & Departr & & & & \\
\hline
\end{tabular}


Map 4.1 Section 8 Density Distributions

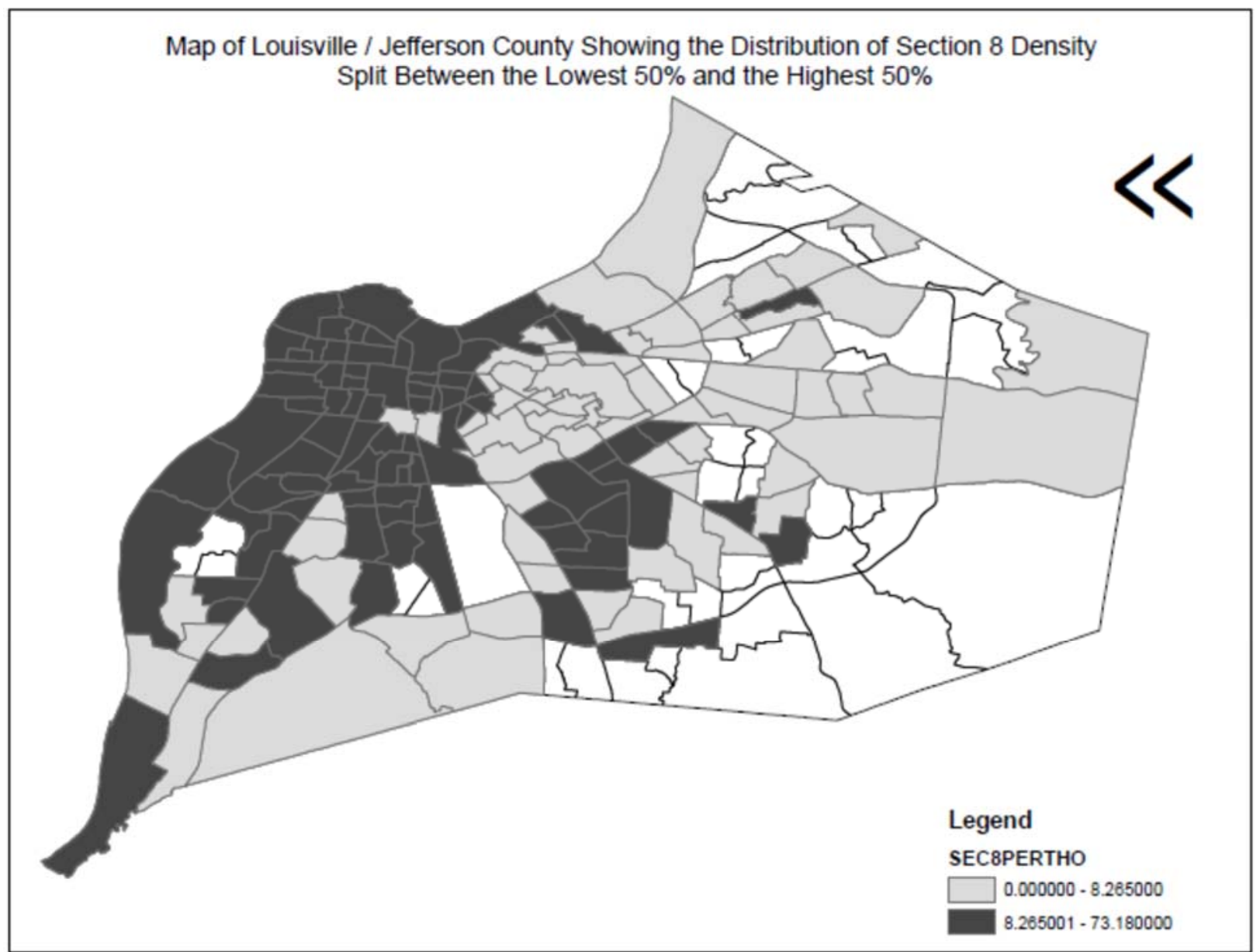


Split Regression Section 8 density, most dense/least dense $-75 / 25$

The previous regressions led to a consideration that smaller doses of Section 8 housing might have a smaller impact on the assessed values in the surrounding community. Considering this idea, another split regression was run, separating Section 8 densities into the 75 percent most dense and the 25 percent least dense Section 8 housing units within the Census tracts. The technique was identical to earlier split regressions. In this instance, the 128 tracts with the higher Section 8 densities per 1000 residents and the remaining 43 tracts with the least dense number of Section 8 units per 1000 people were grouped together in the split.

The results were informative. In the most dense Section 8 areas of Louisville, the density of Section 8 units per 1000 residents in these 128 census tracts varied, from a low of 2.5 units per 1000 to a high of 73.2 Section 8 units per 1000 residents. The non-white population in these tracts varied from 1.7 percent to 99 percent, which covers the spectrum of integration and segregation. In this $75^{\text {th }}$ percentile of highest Section 8 densities, the negative relationship between the test variable and mean assessed valuations was significant. In most years of the study, the results were at a significance of $\mathrm{p}$ less than or equal to 0.001 ; only the year 2000 had less significance, with a $p$ value of .01 . The other variables in the regression behaved as expected.

The lowest 25 th percentile of Section 8 housing density was represented by 43 Census tracts. The density of Section 8 units per 1000 residents varied from zero to 2.5 units per 1000 residents. In these areas, the non-white percentage of residents varied from 1 percent to 42 percent. The median housing value of the less dense Section 8 area in 
2010 was $\$ 368,000$; this compares to $\$ 262,000$ in the more dense area of the split regression. There was still a relationship between the variables; however, in three of the four years, the significance was at a $p$ value of less than or equal to 0.05 . Only in 2006 was the $\mathrm{p}$ value at .01 .

The amount of variation explained by the models in this split regression was strong, keeping all other independent variables constant. Adjusted R square values for the models ranged from a low of 0.519 to a high of 0.659 . This suggests the possibility that smaller doses of Section 8 housing could have a smaller impact on adjacent housing values. The regression tables and associated descriptive measures for this case follow. Following is a map of the areas of Louisville, with these Section 8 densities. It shows that the highest assessed values in Louisville are in the east and northeast portions of the city. The southeast portion is less dense and does not have any associated Section 8 housing stock. 
Table 4.8 Model 4A - Split Regression Section 8 density - 75\% most dense

\begin{tabular}{|c|c|c|c|c|c|c|c|c|}
\hline \multirow[t]{2}{*}{ Dependent Variable } & \multicolumn{2}{|c|}{$\begin{array}{l}\text { Mean Assessed Value (MAV) } \\
\text { Split (highest } 75 \text { percentile } \\
\text { Section } 8 \text { density) MAV-2000 }\end{array}$} & \multicolumn{2}{|c|}{$\begin{array}{l}\text { Mean Assessed Value (MAV) } \\
\text { Split (highest } 75 \text { percentile } \\
\text { Section } 8 \text { density) MAV-2006 }\end{array}$} & \multicolumn{2}{|c|}{$\begin{array}{l}\text { Mean Assessed Value (MAV) } \\
\text { Split (highest } 75 \text { percentile } \\
\text { Section } 8 \text { density MAV-2008 }\end{array}$} & \multicolumn{2}{|c|}{$\begin{array}{l}\text { Mean Assessed Value (MAV) } \\
\text { Split (highest } 75 \text { percentile } \\
\text { Section } 8 \text { density) MAV-2010 }\end{array}$} \\
\hline & $\begin{array}{l}\text { Unstandardized } \\
\text { Coefficient } \\
\text { B }\end{array}$ & $\begin{array}{c}\text { Standardized } \\
\text { beta }\end{array}$ & $\begin{array}{l}\text { Unstandardized } \\
\text { Coefficient } \\
\text { B }\end{array}$ & $\begin{array}{l}\text { Standardized } \\
\text { beta }\end{array}$ & $\begin{array}{l}\text { Unstandardized } \\
\text { Coefficient } \\
\text { B }\end{array}$ & $\begin{array}{l}\text { Standardized } \\
\text { beta }\end{array}$ & $\begin{array}{l}\text { Unstandardized } \\
\text { Coefficient } \\
\text { B }\end{array}$ & $\begin{array}{l}\text { Standardized } \\
\text { beta }\end{array}$ \\
\hline $\begin{array}{l}\text { Section } 8 \text { units per } \\
1000 \text { persons }\end{array}$ & $-549.699^{* *}$ & $-0.262^{* *}$ & $-923.005^{* * * *}$ & $-0.369^{* * * *}$ & $-1309.31^{* * *}$ & $-0.465^{* * *}$ & $-1372.076^{* * *}$ & $-0.455^{* * *}$ \\
\hline $\begin{array}{l}\text { Percent of vacant units. } \\
\left.2000 \text { (ratio* }{ }^{*} 100\right)\end{array}$ & 195.415 & 0.025 & 1209.202 & 0.127 & 2156.854 & 0.209 & 2224.138 & 0.201 \\
\hline Population 2000 & $3.169^{* *}$ & $0.164^{* *}$ & 3.111 & 0.135 & 2.318 & 0.089 & 2.494 & 0.09 \\
\hline $\begin{array}{l}\text { Percent of non-white } \\
\text { residents, 2000 } \\
\text { (ratio*100) }\end{array}$ & $-264.391^{* *}$ & $-0.258^{* *}$ & -253.652 & -0.203 & -250.993 & -0.179 & $-342.104^{*}$ & $-0.228^{*}$ \\
\hline $\begin{array}{l}\text { Miles to nearest } \\
\text { superfund site }\end{array}$ & $5746.528^{* * *}$ & $0.22^{* * *}$ & $7386.581^{* *}$ & $0.236^{* *}$ & $8176.043^{* *}$ & $0.232^{* *}$ & $8499.351^{* *}$ & $0.226^{* *}$ \\
\hline $\begin{array}{c}\text { Inside the inner } \\
\text { beltway (Watterson, I- } \\
\text { 264) dummy variable } \\
(1 / 0)\end{array}$ & $17466.88^{* * *}$ & $0.263^{* * *}$ & $22486.123^{* *}$ & $0.28^{* *}$ & $26527.997^{* *}$ & $0.295^{* *}$ & $26922.867^{* *}$ & $0.28^{* *}$ \\
\hline $\begin{array}{c}\text { Outside the outer } \\
\text { beltway (Gene Snyder, } \\
\text { I-265) dummy variable } \\
(1 / 0)\end{array}$ & $-17012.631^{*}$ & $-0.147^{*}$ & $-20451.424^{*}$ & $-0.148^{*}$ & $-22418.894^{*}$ & $-0.144^{*}$ & $-22924.363^{*}$ & $-0.138^{*}$ \\
\hline $\begin{array}{l}\text { Tree density (per } \\
\text { person) }\end{array}$ & 3382.375 & 0.062 & 1895.104 & 0.029 & 6513.768 & 0.088 & 6946.445 & 0.088 \\
\hline $\begin{array}{l}\text { Percent of rental units, } \\
2000 \text { (ratio* } 100 \text { ) }\end{array}$ & -60.125 & -0.038 & -19.656 & -0.01 & 93.885 & 0.043 & 163.374 & 0.07 \\
\hline $\begin{array}{c}\text { Total crimes per } \\
100,000 \text { residents, } \\
2004 \text {, by LMPD } \\
\text { district }\end{array}$ & $-3470.572^{* * *}$ & $-0.366^{* * *}$ & $-3660.605^{* * *}$ & $-0.302^{* * *}$ & $-3031.194^{*}$ & $-0.23^{*}$ & $-3315.327^{* *}$ & $-0.235^{* *}$ \\
\hline $\begin{array}{c}\text { Median Housing Age, } \\
2000\end{array}$ & -189.447 & -0.076 & -503.285 & -0.17 & $-665.085^{*}$ & $-0.2^{*}$ & $-708.48^{*}$ & $-0.199^{*}$ \\
\hline
\end{tabular}

\begin{tabular}{l|c|c|c|c|}
\cline { 2 - 5 } Intercept & $88130^{* * *}$ & $120541^{* * *}$ & $121022^{* * *}$ & $122626^{* * *}$ \\
R Square & .688 & .609 & .561 & .598 \\
Adjusted R Square & .659 & .572 & .519 & .560 \\
$\mathrm{~N}$ & 128 & 126 & 127 & 127 \\
Significance & $.000^{* * *}$ & $.000^{* * *}$ & $.000^{* * *}$ & $.000^{* * *}$ \\
\hline
\end{tabular}

Notes: $* p \leq .05 ; \cdots=p \leq .01 ; \cdots=p \leq .001$ 
Table 4.9 Model 4B - Split Regression Section 8 density - 25\% least dense

\begin{tabular}{|c|c|c|c|c|c|c|c|c|}
\hline \multirow[t]{2}{*}{ Dependent Variable } & \multicolumn{2}{|c|}{$\begin{array}{l}\text { Mean Assessed Value (MAV) } \\
\text { Split (lowest } 25 \text { percentile } \\
\text { Section } 8 \text { density) MAV-2000 }\end{array}$} & \multicolumn{2}{|c|}{$\begin{array}{l}\text { Mean Assessed Value (MAV) } \\
\text { Split (lowest } 25 \text { percentile } \\
\text { Section } 8 \text { density) MAV-2006 }\end{array}$} & \multicolumn{2}{|c|}{$\begin{array}{l}\text { Mean Assessed Value (MAV) } \\
\text { Split (lowest } 25 \text { percentile } \\
\text { Section } 8 \text { density) MAV-2008 }\end{array}$} & \multicolumn{2}{|c|}{$\begin{array}{l}\text { Mean Assessed Value (MAV) } \\
\text { Split (lowest } 25 \text { percentile } \\
\text { Section } 8 \text { density) MAV-2010 }\end{array}$} \\
\hline & $\begin{array}{l}\text { Unstandardized } \\
\text { Coefficient } \\
\text { B }\end{array}$ & $\begin{array}{l}\text { Standardized } \\
\text { beta }\end{array}$ & $\begin{array}{l}\text { Unstandardized } \\
\text { Coefficient } \\
\text { B }\end{array}$ & $\begin{array}{c}\text { Standardized } \\
\text { beta }\end{array}$ & $\begin{array}{l}\text { Unstandardized } \\
\text { Coefficient } \\
\text { B }\end{array}$ & $\begin{array}{l}\text { Standardized } \\
\text { beta }\end{array}$ & $\begin{array}{l}\text { Unstandardized } \\
\text { Coefficient } \\
\text { B }\end{array}$ & $\begin{array}{c}\text { Standardized } \\
\text { beta }\end{array}$ \\
\hline $\begin{array}{l}\text { Section } 8 \text { units per } \\
1000 \text { persons }\end{array}$ & $-21415.687^{*}$ & $-0.346^{*}$ & $-26370.79 *$ & $-0.329 *$ & $-35377.855 * *$ & $-0.461^{* *}$ & $-28316.903^{*}$ & $-0.328^{*}$ \\
\hline $\begin{array}{l}\text { Percent of vacant units, } \\
2000 \text { (ratio*100) }\end{array}$ & $5751.256^{*}$ & $0.366^{*}$ & 5809.87 & 0.286 & 5307.717 & 0.273 & $7064.603^{*}$ & $0.323^{*}$ \\
\hline Population 2000 & 4.83 & 0.157 & 6.8 & 0.171 & 3.69 & 0.096 & 6.971 & 0.163 \\
\hline $\begin{array}{l}\text { Percent of non-white } \\
\text { residents, 2000 } \\
\text { (ratio*100) }\end{array}$ & $2862.185^{*}$ & $0.399 *$ & $4489.434^{*}$ & $0.484^{*}$ & 3037.761 & 0.341 & $4397.484^{*}$ & $0.44^{*}$ \\
\hline $\begin{array}{l}\text { Miles to nearest } \\
\text { superfund site }\end{array}$ & 4724.355 & 0.141 & 4885.684 & 0.112 & -3773.097 & -0.088 & 5245.185 & 0.112 \\
\hline $\begin{array}{c}\text { Inside the inner } \\
\text { beltway (Watterson, I- } \\
\text { 264) dummy variable } \\
(1 / 0)\end{array}$ & 25445.69 & 0.257 & 39124.077 & 0.305 & 31904.746 & 0.258 & 44267.653 & 0.321 \\
\hline $\begin{array}{c}\text { Outside the outer } \\
\text { beltway (Gene Snyder, } \\
\text { I-265) dummy variable } \\
(1 / 0)\end{array}$ & 14352.205 & 0.102 & 15641.901 & 0.086 & 18599.106 & 0.106 & 16207.464 & 0.082 \\
\hline $\begin{array}{l}\text { Tree density (per } \\
\text { person) }\end{array}$ & 734.047 & 0.019 & 5615.471 & 0.112 & 9449.678 & 0.197 & 6415.264 & 0.119 \\
\hline $\begin{array}{l}\text { Percent of rental units, } \\
2000 \text { (ratio*100) }\end{array}$ & $-1646.928^{* * *}$ & $-0.693^{* * *}$ & $-2154.481^{* * *}$ & $-0.701^{* * *}$ & $-1907.052^{* *}$ & $-0.649 * *$ & $-2310.238^{* * *}$ & $-0.698^{* * *}$ \\
\hline $\begin{array}{l}\text { Total crimes per } \\
100,000 \text { residents, } \\
2004, \text { by LMPD } \\
\text { district }\end{array}$ & $-14112.506^{*}$ & $-0.378^{*}$ & $-16589.916^{*}$ & $-0.343^{*}$ & $-14969.145^{*}$ & $-0.323^{*}$ & $-18770.162^{*}$ & $-0.361^{*}$ \\
\hline $\begin{array}{c}\text { Median Housing Age, } \\
2000\end{array}$ & 559.586 & 0.203 & 482.687 & 0.136 & 317.16 & 0.093 & 751.067 & 0.196 \\
\hline Intercept & 1450 & & 18191 & & 24756 & $5 * * *$ & 19603 & \\
\hline R Square & .72 & & .683 & & .70 & & .67 & \\
\hline Adjusted R Square & .62 & & .571 & & .60 & & .56 & \\
\hline $\mathrm{N}$ & 4 & & 43 & & 42 & & 43 & \\
\hline Significance & .000 & & $.000^{*}$ & & .000 & & $.000^{*}$ & \\
\hline
\end{tabular}

Notes: $*=p \leq .05 ; *=p \leq .01 ; * *=p \leq .001$ 
Table 4.10 Descriptives for Section 8 Density - 75\% most dense

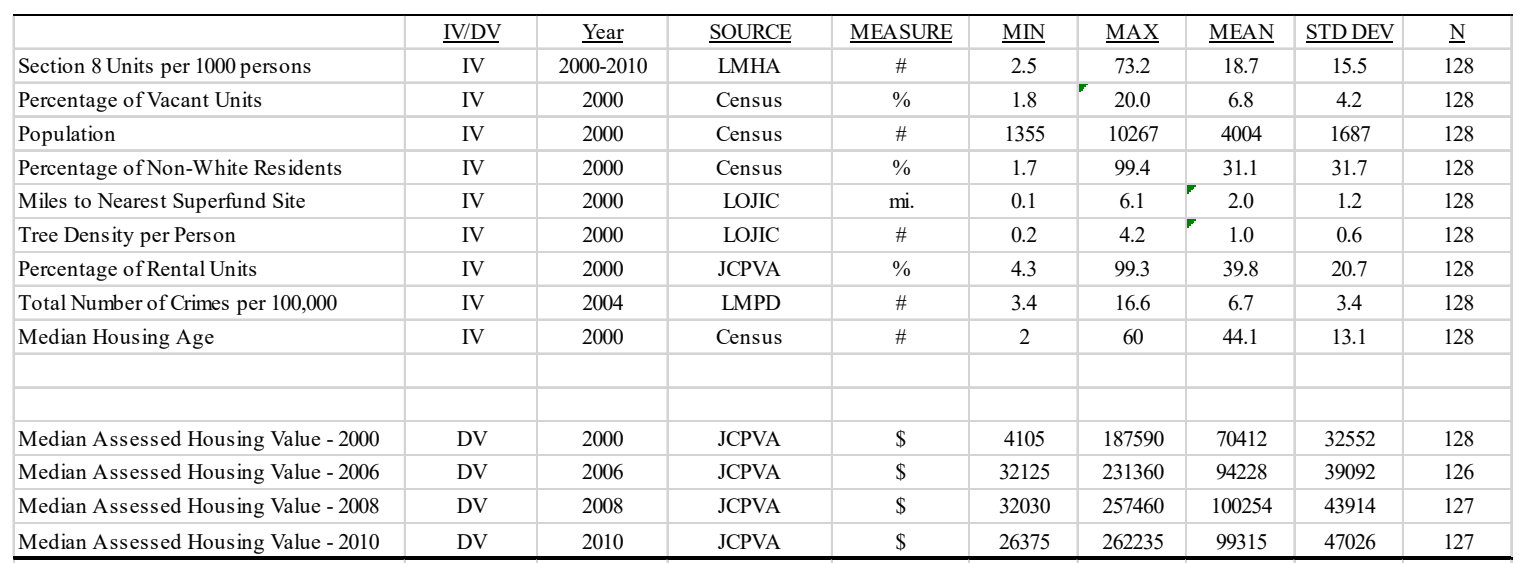

Notes: LMHA - Louisville Metro Housing Authority; US Census, 2000 Census; LOJIC - Louisville/Jefferson County Information Consortium; JCPVA: Jefferson County Property Valuation Administrator; LMPD -Louisville Metro Police Department. 
Table 4.11 Descriptives for Section 8 Density $-25 \%$ least dense

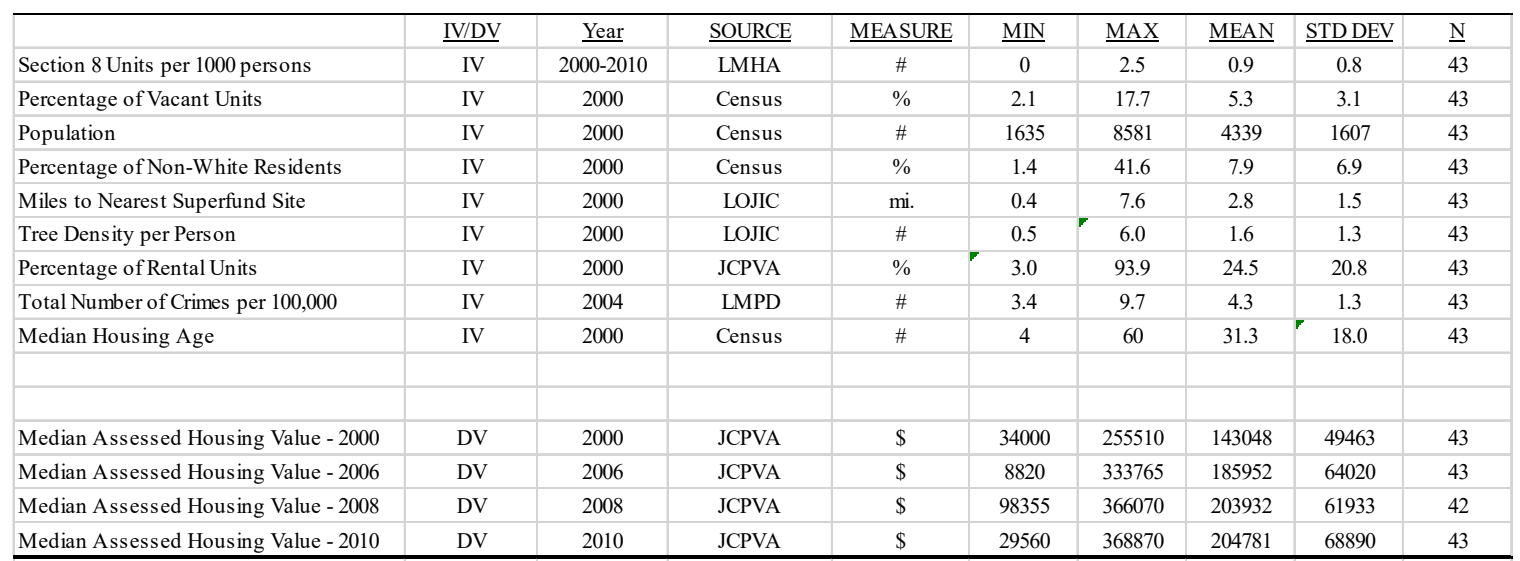

Notes: LMHA - Louisville Metro Housing Authority; US Census, 2000 Census; LOJIC - Louisville/Jefferson County Information Consortium; JCPVA: Jefferson County Property Valuation Administrator; LMPD -Louisville Metro Police Department. 
Map 4.2 Section 8 Density Distributions - 75/25

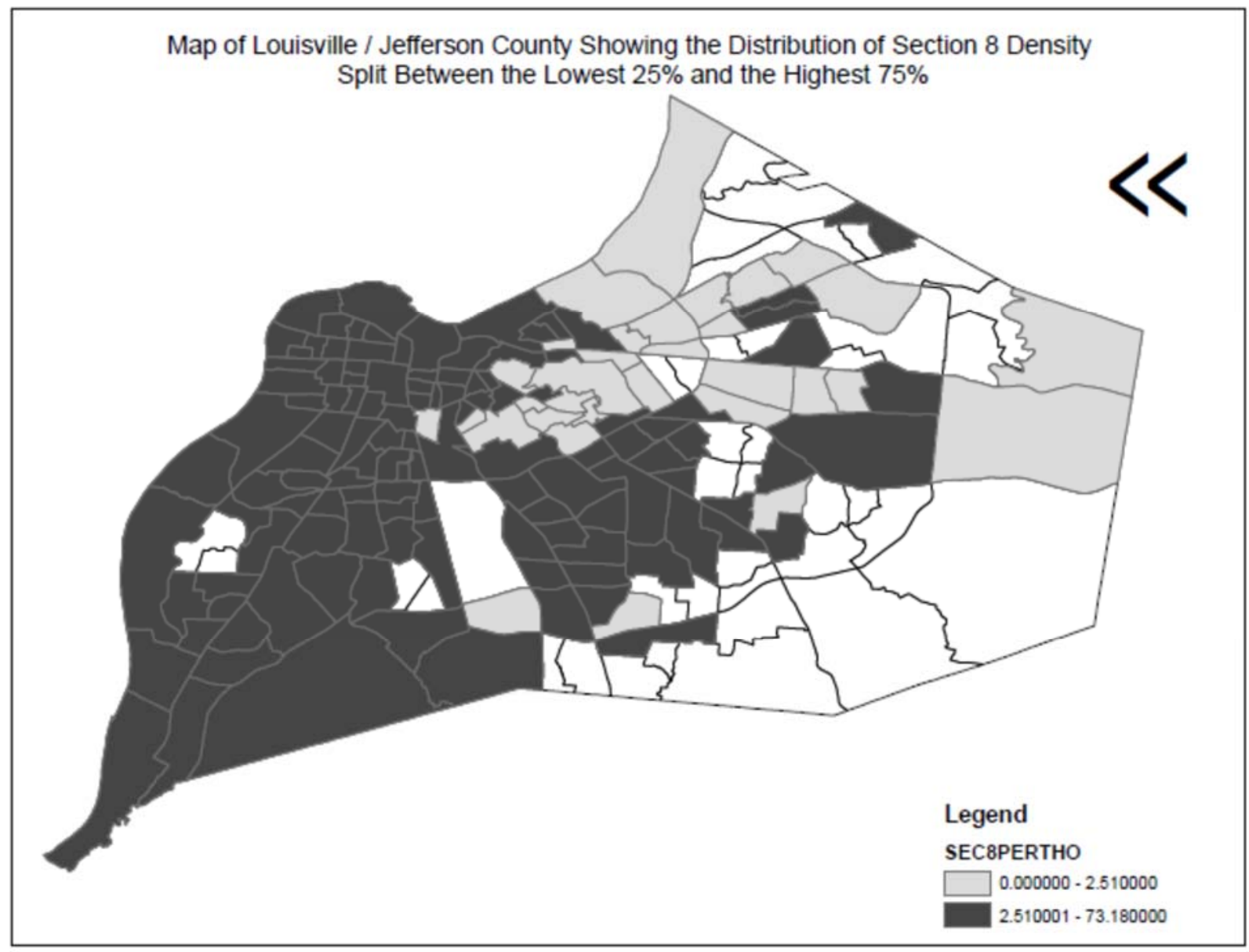


Split Regression Mean Assessed Value, high MAV/low MAV - 50/50

The next regression was performed to evaluate the impact of mean assessed valuations (MAV) rather than Section 8 densities. A similar process of splitting the Census tracts into equal groups, in terms of numbers, was performed. Since data is available for the four years used in the study, a separate regression was required for each of these years. The mean assessed valuation, for each of the years in the study, was determined by finding the assessed value in which $50 \%$ of the census tracts had a greater mean value and $50 \%$ of the census tracts had a lower mean value. The regression results and the descriptive statistics for the split regression cases follow. In this instance, the mean assessed values were available in each of the study years, so there are four descriptive statistic tables and four associated maps. The four regressions for either the lowest or the highest mean assessed values are combined into individual tables.

One benefit of this regression is that the mean values can be tested against the general knowledge of the community. The mean assessed housing values increased over time from 2000 to 2008 , yet remained stable from 2008 to 2010 due to the real estate recession.

In the case of the 50 percent highest mean assessed valuations, the mean in the year 2000 started at $\$ 124,979$ and grew by almost 31 percent to $\$ 163,459$ in the year 2006, an annual growth rate of 5 percent. The value then grew at a smaller rate of 4 percent per year to a value of $\$ 175,908$ in the year 2008 . In the recessionary period of 2008 to 2010, the mean assessed value in the highest valued census tracts grew at just 0.8 
percent to a value of $\$ 178,659$. In the case of the 50 percent lowest mean assessed valuation census tracts, the results were similar. From 2000 to 2006 the mean assessed values grew from $\$ 52,212$ to $\$ 71,451$, a growth rate of 37 percent, or an annual rate of 6 percent. From 2006 to 2008 the growth continued at an annual rate of 3 percent to $\$ 75,952$, and then declined to the year 2010 to a value of $\$ 72,489$ which reflected an annual decline of 2 percent.

The results of this regression show no significance, as defined earlier, for Section 8 housing units based upon this split. This mixed result from earlier models possibly points to the conclusion that if Section 8 housing is distributed to larger areas, which will result in lower Section 8 concentrations, the relationship between Section 8 and decreasing neighborhood values may be mitigated. Some of the control variables did show significance as would be expected related to a split such as this. For example, the percent of vacant units in the more expensive areas of town have a greater impact on housing values, as does the percent of rental units and crime. In the lower half of the assessed values data, there is significance only in the year 2006, between assessed values and Section 8 densities.

This lack of significance between mean assessed valuations and Section 8 housing densities runs counter to the other regressions. This looked like a closed case of a negative relationship between the independent variable and the test variable, but this split showed otherwise. It is uncertain whether the result is a methodological or statistical issue that is masking the result, but there is enough data to not be conclusive with regards to this relationship. 
Maps for each of the four years of the study were created to provide information on the locations of the higher and lower priced residential real estate areas. By mapping information over time, researchers can evaluate movement in housing values within the market.

The maps show that the areas of highest assessed values in the city overlay closely with the least dense Section 8 densities, with the converse being true as well. There is little if any change from year to year in median assessed value locations over the 10 years of this study. There are a few Census tracts in the southwest portion of the city that change from the upper to the lower percentile, from 2000 to 2006. Otherwise, the city has remained economically split in a consistent manner. 


\section{Table 4.12 Model 5A - Split Regression Mean Assessed Value - 50\% most expensive}

\begin{tabular}{|c|c|c|c|c|c|c|c|c|}
\hline \multirow[t]{2}{*}{ Dependent Variable } & \multicolumn{2}{|c|}{$\begin{array}{l}\text { Mean Assessed Value (MAV) } \\
\text { Split (highest } 50 \text { percentile of } \\
\text { MAV, } \$ 80,227 \text { ) MAV-2000 }\end{array}$} & \multicolumn{2}{|c|}{$\begin{array}{l}\text { Mean Assessed Value (MAV) } \\
\text { Split (highest } 50 \text { percentile of } \\
\text { MAV, } \$ 103,842 \text { ) MAV-2006 }\end{array}$} & \multicolumn{2}{|c|}{$\begin{array}{l}\text { Mean Assessed Value (MAV) } \\
\text { Split (highest } 50 \text { percentile of } \\
\text { MAV, } \$ 110,272 \text { ) MAV-2008 }\end{array}$} & \multicolumn{2}{|c|}{$\begin{array}{l}\text { Mean Assessed Value (MAV) } \\
\text { Split (highest } 50 \text { percentile of } \\
\text { MAV, } \$ 110,000 \text { ) MAV-2010 }\end{array}$} \\
\hline & $\begin{array}{c}\text { Unstandardized } \\
\text { Coefficient } \\
\text { B }\end{array}$ & $\begin{array}{c}\text { Standardized } \\
\text { beta }\end{array}$ & $\begin{array}{c}\text { Unstandardized } \\
\text { Coefficient } \\
\text { B }\end{array}$ & $\begin{array}{c}\text { Standardized } \\
\text { beta }\end{array}$ & $\begin{array}{c}\text { Unstandardized } \\
\text { Coefficient } \\
\text { B }\end{array}$ & $\begin{array}{c}\text { Standardized } \\
\text { beta }\end{array}$ & $\begin{array}{c}\text { Unstandardized } \\
\text { Coefficient } \\
\text { B }\end{array}$ & $\begin{array}{c}\text { Standardized } \\
\text { beta }\end{array}$ \\
\hline $\begin{array}{c}\text { Section } 8 \text { units per } \\
1000 \text { persons }\end{array}$ & -1551.46 & -0.179 & -2084.927 & -0.197 & -2529.919 & -0.225 & -2494.823 & -0.22 \\
\hline $\begin{array}{l}\text { Percent of vacant } \\
\text { units, } 2000 \\
\text { (ratio*100) }\end{array}$ & $6708.122^{* * *}$ & $0.418^{* * *}$ & $8142.601 * * *$ & $0.439 * * *$ & $9177.753 * * *$ & $0.529 * * *$ & $9980.277^{* * *}$ & $0.553^{* * *}$ \\
\hline Population 2000 & 1.107 & 0.046 & 0.881 & 0.029 & 1.007 & 0.031 & 0.849 & 0.025 \\
\hline $\begin{array}{l}\text { Percent of non-white } \\
\text { residents, } 2000 \\
(\text { ratio*100) }\end{array}$ & 365.986 & 0.07 & 1227.278 & 0.206 & 1157.511 & 0.217 & 1004.596 & 0.181 \\
\hline $\begin{array}{l}\text { Miles to nearest } \\
\text { superfund site }\end{array}$ & 2323.049 & 0.069 & -40.943 & -0.001 & 1627.854 & 0.036 & 1448.259 & 0.031 \\
\hline $\begin{array}{c}\text { Inside the inner } \\
\text { beltway (Watterson, I- } \\
\text { 264) dummy variable } \\
(1 / 0)\end{array}$ & $38725.551^{* * *}$ & $0.419^{* * *}$ & $52136.474^{* *}$ & $0.456^{* *}$ & $65658.373^{* * *}$ & $0.543 * * *$ & $65518.34 * * *$ & $0.521 * * *$ \\
\hline $\begin{array}{c}\text { Outside the outer } \\
\text { beltway (Gene } \\
\text { Snyder, I-265) } \\
\text { dummy variable (1/0) }\end{array}$ & -5791.135 & -0.046 & 5443.948 & 0.033 & $4554.119 *$ & $0.026^{*}$ & 4743.727 & 0.026 \\
\hline $\begin{array}{c}\text { Tree density (per } \\
\text { person) }\end{array}$ & 5511.549 & 0.134 & $10316.202 *$ & $0.202 *$ & $11409.117 * * *$ & $0.207 * * *$ & 10952.032 & 0.191 \\
\hline $\begin{array}{l}\text { Percent of rental } \\
\text { units, } 2000 \\
\text { (ratio*100) }\end{array}$ & $-989.106 * * *$ & $-0.407 * * *$ & $-1444.967^{* * *}$ & $-0.537 * * *$ & -1627.498 & -0.603 & $-1673.126^{* * *}$ & $-0.595^{* * *}$ \\
\hline $\begin{array}{l}\text { Total crimes per } \\
100,000 \text { residents, } \\
\text { 2004, by LMPD } \\
\text { district }\end{array}$ & $-13051.008^{* *}$ & $-0.276^{* *}$ & $-10850.13^{*}$ & $-0.267^{*}$ & -6221.126 & -0.245 & $-6892.591 *$ & $-0.261^{*}$ \\
\hline $\begin{array}{c}\text { Median Housing Age, } \\
2000\end{array}$ & -395.619 & -0.141 & -459.885 & -0.135 & -526.288 & -0.147 & -523.324 & -0.14 \\
\hline Intercept & 16092 & $4 * * *$ & 186467 & $7 * * *$ & 170112 & $2 * * *$ & 177466 & $5 * * *$ \\
\hline R Square & .55 & & .52 & & .50 & & .52 & \\
\hline Adjusted R Square & .48 & & .45 & & .432 & & .445 & \\
\hline $\mathrm{N}$ & 85 & & 84 & & 84 & & 85 & \\
\hline Significance & $.000^{\circ}$ & & $.000^{*}$ & & $.000^{*}$ & & $.000^{*}$ & \\
\hline
\end{tabular}


Table 4.13 Descriptives for Mean Assessed Value, 2000 - 50\% most expensive

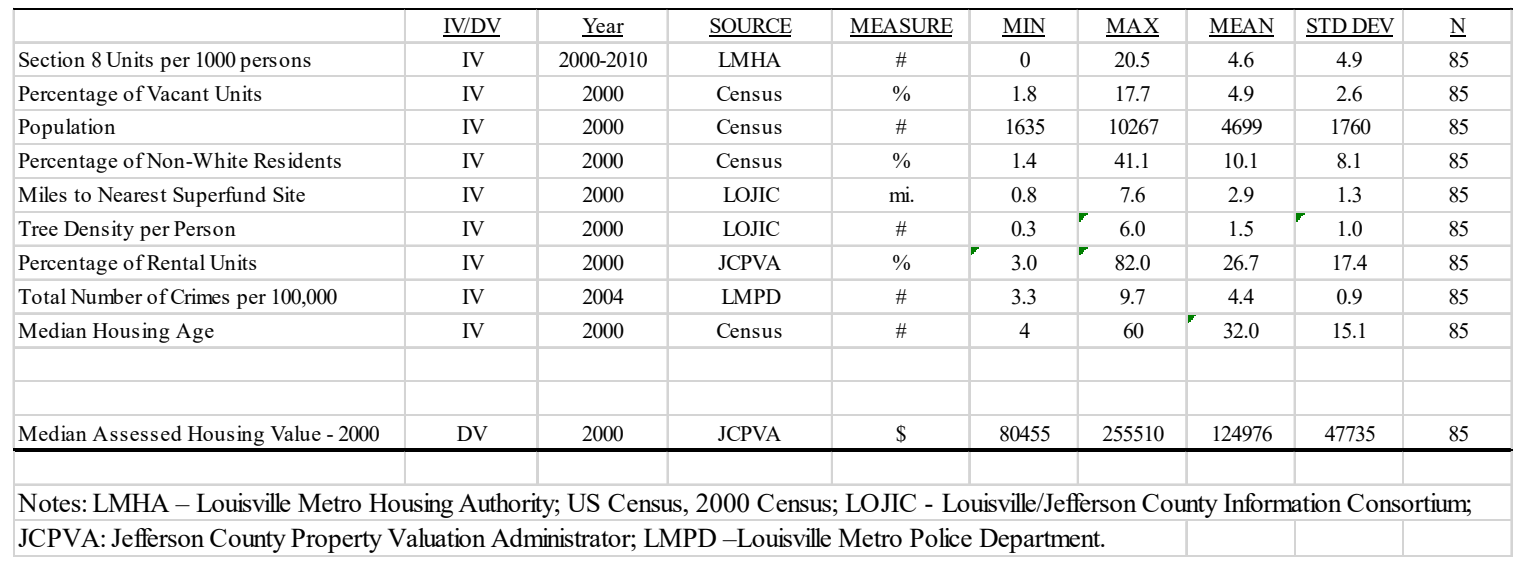


Table 4.14 Descriptives for Mean Assessed Value, 2006 - 50\% most expensive

\begin{tabular}{|c|c|c|c|c|c|c|c|c|c|}
\hline & $\underline{\mathrm{IV} / \mathrm{DV}}$ & $\underline{\text { Year }}$ & $\underline{\text { SOURCE }}$ & MEASURE & $\underline{\mathrm{MIN}}$ & $\underline{\text { MAX }}$ & MEAN & STD DEV & $\underline{N}$ \\
\hline Section 8 Units per 1000 persons & IV & $2000-2010$ & LMHA & \# & 0 & 27.9 & 4.4 & 5.1 & 84 \\
\hline Percentage of Vacant Units & IV & 2000 & Census & $\%$ & 1.8 & 17.7 & 5.2 & 2.9 & 84 \\
\hline Population & IV & 2000 & Census & \# & 1635 & 10267 & 4616 & 1783 & 84 \\
\hline Percentage of Non-White Residents & IV & 2000 & Census & $\%$ & 1.4 & 46.7 & 10.6 & 9.0 & 84 \\
\hline Miles to Nearest Superfund Site & IV & 2000 & LOJIC & mi. & 0.8 & 7.6 & 2.9 & 1.3 & 84 \\
\hline Tree Density per Person & IV & 2000 & LOJIC & \# & 0.3 & 6.0 & 1.5 & 1.1 & 84 \\
\hline Percentage of Rental Units & IV & 2000 & JCPVA & $\%$ & 3.0 & 93.9 & 28.4 & 20.0 & 84 \\
\hline Total Number of Crimes per 100,000 & IV & 2004 & LMPD & $\#$ & 3.3 & 9.7 & 4.5 & 1.3 & 84 \\
\hline Median Housing Age & IV & 2000 & Census & \# & 4 & 60 & 32.5 & 15.8 & 84 \\
\hline Median Assessed Housing Value - 2006 & DV & 2006 & JCPVA & $\$$ & 105000 & 333765 & 163459 & 53687 & 84 \\
\hline \multicolumn{10}{|c|}{ Notes: LMHA - Louisville Metro Housing Authority; US Census, 2000 Census; LOJIC - Louisville/Jefferson County Information Consortium; } \\
\hline JCPVA: Jefferson County Property & uation $\mathrm{A}$ & nistrator; L & D -Louis & Metro Polic & Departm & & & & \\
\hline
\end{tabular}


Table 4.15 Descriptives for Mean Assessed Value, 2008 - 50\% most expensive

\begin{tabular}{|c|c|c|c|c|c|c|c|c|c|}
\hline & $\underline{\mathrm{IV} / \mathrm{DV}}$ & $\underline{\text { Year }}$ & $\underline{\text { SOURCE }}$ & MEASURE & $\underline{\mathrm{MIN}}$ & $\underline{\mathrm{MAX}}$ & MEAN & $\underline{\text { STD DEV }}$ & $\underline{\mathrm{N}}$ \\
\hline Section 8 Units per 1000 persons & IV & $2000-2010$ & LMHA & \# & 0 & 27.9 & 4.5 & 5.1 & 84 \\
\hline Percentage of Vacant Units & IV & 2000 & Census & $\%$ & 1.8 & 20.0 & 5.4 & 3.3 & 84 \\
\hline Population & IV & 2000 & Census & \# & 1635 & 10267 & 4504 & 1776 & 84 \\
\hline Percentage of Non-White Residents & IV & 2000 & Census & $\%$ & 1.4 & 65.9 & 11.3 & 10.8 & 84 \\
\hline Miles to Nearest Superfund Site & IV & 2000 & LOJIC & mi. & 0.8 & 7.6 & 2.9 & 1.3 & 84 \\
\hline Tree Density per Person & IV & 2000 & LOJIC & $\#$ & 0.3 & 6.0 & 1.5 & 1.0 & 84 \\
\hline Percentage of Rental Units & IV & 2000 & JCPVA & $\%$ & 3.0 & 97.2 & 29.3 & 21.4 & 84 \\
\hline Total Number of Crimes per 100,000 & IV & 2004 & LMPD & \# & 3.3 & 16.6 & 4.8 & 2.3 & 84 \\
\hline Median Housing Age & IV & 2000 & Census & \# & 4 & 60 & 33.0 & 16.1 & 84 \\
\hline & & & & & & & & & \\
\hline Median Assessed Housing Value - 2008 & DV & 2008 & JCPVA & $\$$ & 110900 & 366070 & 175908 & 57823 & 84 \\
\hline
\end{tabular}

Notes: LMHA - Louisville Metro Housing Authority; US Census, 2000 Census; LOJIC - Louisville/Jefferson County Information Consortium; JCPVA: Jefferson County Property Valuation Administrator; LMPD -Louisville Metro Police Department. 
Table 4.16 Descriptives for Mean Assessed Value, 2010 - 50\% most expensive

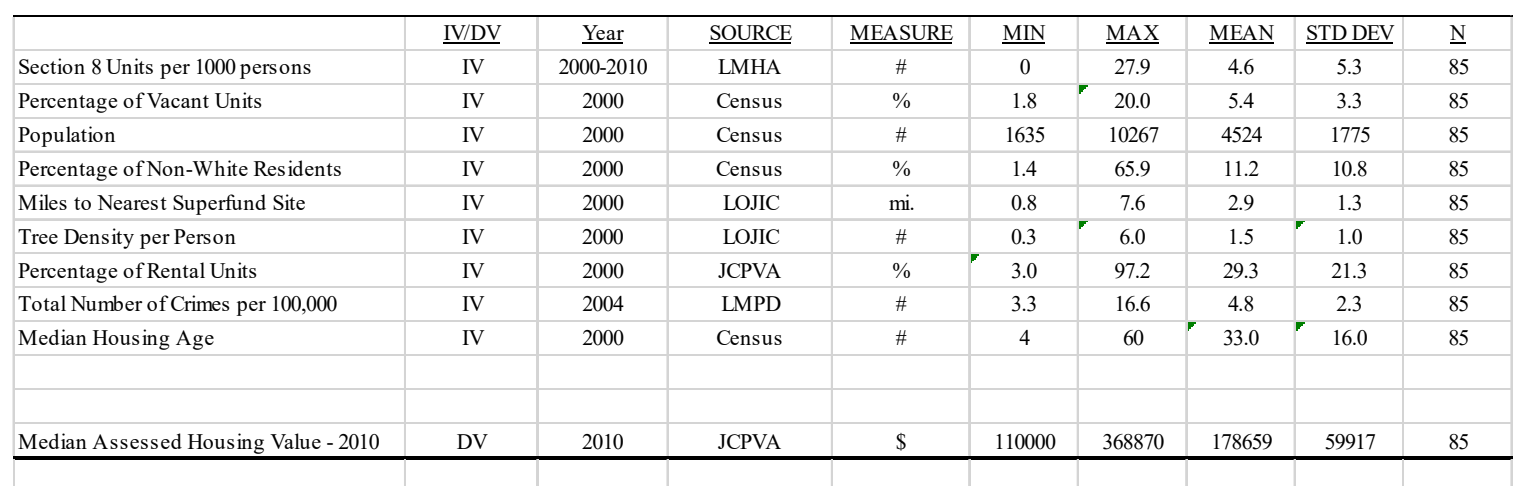

Notes: LMHA - Louisville Metro Housing Authority; US Census, 2000 Census; LOJIC - Louisville/Jefferson County Information Consortium; JCPVA: Jefferson County Property Valuation Administrator; LMPD -Louisville Metro Police Department. 
Table 4.17 Model 5B - Split Regression Mean Assessed Value - 50\% least expensive

\begin{tabular}{|c|c|c|c|c|c|c|c|c|}
\hline \multirow[t]{2}{*}{ Dependent Variable } & \multicolumn{2}{|c|}{$\begin{array}{c}\text { Mean Assessed Value (MAV) } \\
\text { Split (lowest } 50 \text { percentile of } \\
\text { MAV, } \$ 80,227 \text { ) MAV-2000 }\end{array}$} & \multicolumn{2}{|c|}{$\begin{array}{l}\text { Mean Assessed Value (MAV) } \\
\text { Split (lowest } 50 \text { percentile of } \\
\text { MAV, } \$ 103,842 \text { ) MAV-2006 }\end{array}$} & \multicolumn{2}{|c|}{$\begin{array}{l}\text { Mean Assessed Value (MAV) } \\
\text { Split (lowest } 50 \text { percentile of } \\
\text { MAV, } \$ 110,272 \text { ) MAV-2008 }\end{array}$} & \multicolumn{2}{|c|}{$\begin{array}{l}\text { Mean Assessed Value (MAV) } \\
\text { Split (lowest } 50 \text { percentile of } \\
\text { MAV, } \$ 110,000 \text { ) MAV-2010 }\end{array}$} \\
\hline & $\begin{array}{c}\text { Unstandardized } \\
\text { Coefficient } \\
\text { B }\end{array}$ & $\begin{array}{l}\text { Standardized } \\
\text { beta }\end{array}$ & $\begin{array}{c}\text { Unstandardized } \\
\text { Coefficient } \\
\text { B }\end{array}$ & $\begin{array}{l}\text { Standardized } \\
\text { beta }\end{array}$ & $\begin{array}{c}\text { Unstandardized } \\
\text { Coefficient } \\
\text { B }\end{array}$ & $\begin{array}{c}\text { Standardized } \\
\text { beta }\end{array}$ & $\begin{array}{c}\text { Unstandardized } \\
\text { Coefficient } \\
\text { B }\end{array}$ & $\begin{array}{c}\text { Standardized } \\
\text { beta }\end{array}$ \\
\hline $\begin{array}{c}\text { Section } 8 \text { units per } \\
1000 \text { persons }\end{array}$ & -116.701 & -0.099 & -142.703 & -0.109 & $-321.101^{*}$ & $-0.231^{*}$ & -255.968 & -0.16 \\
\hline $\begin{array}{l}\text { Percent of vacant } \\
\text { units, } 2000 \\
\text { (ratio*100) }\end{array}$ & $-973.027^{*}$ & $-0.23 *$ & -1201.246 & -0.248 & -466.104 & -0.092 & -908.164 & -0.153 \\
\hline Population 2000 & 1.108 & 0.076 & 0.583 & 0.038 & 1.178 & 0.077 & 1.446 & 0.08 \\
\hline $\begin{array}{l}\text { Percent of non-white } \\
\text { residents, 2000 } \\
(\text { ratio*100) }\end{array}$ & $-217.32 * * *$ & $-0.393 * * *$ & -128.989 & -0.21 & -215.766 & -0.333 & $-273.905^{* * *}$ & $-0.363^{* * *}$ \\
\hline $\begin{array}{l}\text { Miles to nearest } \\
\text { superfund site }\end{array}$ & $4263.202^{* *}$ & $0.223^{* *}$ & $6191.123^{* *}$ & $0.303^{* *}$ & $2257.597 * * *$ & $0.103 * * *$ & $4627.724^{*}$ & $0.182^{*}$ \\
\hline $\begin{array}{c}\text { Inside the inner } \\
\text { beltway (Watterson, I } \\
\text { 264) dummy variable } \\
(1 / 0)\end{array}$ & 4180.834 & 0.109 & 5436.313 & 0.128 & 4842.716 & 0.108 & 6335.569 & 0.121 \\
\hline $\begin{array}{c}\text { Outside the outer } \\
\text { beltway (Gene } \\
\text { Snyder, I-265) } \\
\text { dummy variable }(1 / 0)\end{array}$ & 362.005 & 0.005 & -972.362 & -0.013 & -9338.896 & -0.115 & -4399.168 & -0.047 \\
\hline $\begin{array}{l}\text { Tree density (per } \\
\text { person) }\end{array}$ & 124.91 & 0.003 & -1794.106 & -0.042 & -5478.045 & -0.125 & -4100.446 & -0.079 \\
\hline $\begin{array}{l}\text { Percent of rental } \\
\text { units, 2000 } \\
\text { (ratio*100) }\end{array}$ & 105.006 & 0.117 & 0.02 & 0 & -61.451 & -0.052 & 74.581 & 0.054 \\
\hline $\begin{array}{c}\text { Total crimes per } \\
\text { 100,000 residents, } \\
\text { 2004, by LMPD } \\
\text { district }\end{array}$ & $-1881.238^{* * *}$ & $-0.365^{* * *}$ & -812.851 & -0.134 & $-1839.629 * *$ & $-0.276^{* *}$ & $-1850.432 *$ & $-0.238^{*}$ \\
\hline $\begin{array}{c}\text { Median Housing Age, } \\
2000\end{array}$ & 110.298 & 0.066 & -355.852 & -0.193 & $-736.391 * * *$ & $-0.38 * * *$ & $-616.161 * *$ & $-0.273 * *$ \\
\hline Intercept & 6426 & $* * *$ & 98706 & $* * *$ & 14018 & $6^{* * *}$ & 122830 & $0 * * *$ \\
\hline R Square & .67 & & .56 & & .75 & & .69 & \\
\hline Adjusted R Square & .62 & & .50 & & .71 & & .65 & \\
\hline $\mathrm{N}$ & 85 & & 84 & & 84 & & 84 & \\
\hline Significance & .000 & & $.000^{*}$ & & $.000^{*}$ & & $.000 *$ & \\
\hline
\end{tabular}

Notes: $*=p \leq .05 ; * *=p \leq .01 ; * * *=p \leq .001$ 
Table 4.18 Descriptives for Mean Assessed Value, 2000 - 50\% least expensive

\begin{tabular}{|c|c|c|c|c|c|c|c|c|c|}
\hline & $\underline{\mathrm{IV} / \mathrm{DV}}$ & $\underline{\text { Year }}$ & $\underline{\text { SOURCE }}$ & MEASURE & $\underline{\mathrm{MIN}}$ & $\underline{\text { MAX }}$ & MEAN & $\underline{\text { STD DEV }}$ & $\underline{\mathrm{N}}$ \\
\hline Section 8 Units per 1000 persons & IV & $2000-2010$ & LMHA & \# & 1.2 & 73.2 & 24.0 & 16.4 & 85 \\
\hline Percentage of Vacant Units & IV & 2000 & Census & $\%$ & 2.2 & 20.0 & 8.0 & 4.6 & 85 \\
\hline Population & IV & 2000 & Census & \# & 1355 & 7278 & 3460 & 1318 & 85 \\
\hline Percentage of Non-White Residents & IV & 2000 & Census & $\%$ & 1.7 & 99.4 & 40.6 & 34.9 & 85 \\
\hline Miles to Nearest Superfund Site & IV & 2000 & LOJIC & mi. & 0.1 & 4.5 & 1.5 & 1.0 & 85 \\
\hline Tree Density per Person & IV & 2000 & LOJIC & $\#$ & 0.2 & 2.4 & 0.9 & 0.5 & 85 \\
\hline Percentage of Rental Units & IV & 2000 & JCPVA & $\%$ & 12.7 & 99.3 & 45.5 & 21.5 & 85 \\
\hline Total Number of Crimes per 100,000 & IV & 2004 & LMPD & \# & 4.4 & 16.6 & 7.8 & 3.7 & 85 \\
\hline Median Housing Age & IV & 2000 & Census & \# & 2 & 60 & 45.5 & 11.6 & 85 \\
\hline & & & & & & & & & \\
\hline Median Assessed Housing Value - 2000 & DV & 2000 & JCPVA & $\$$ & 4105 & 80000 & 52212 & 19290 & 85 \\
\hline
\end{tabular}

Notes: LMHA - Louisville Metro Housing Authority; US Census, 2000 Census; LOJIC - Louisville/Jefferson County Information Consortium; JCPVA: Jefferson County Property Valuation Administrator; LMPD -Louisville Metro Police Department. 
Table 4.19 Descriptives for Mean Assessed Value, 2006 - 50\% least expensive

\begin{tabular}{|c|c|c|c|c|c|c|c|c|c|}
\hline & $\underline{\mathrm{IV} / \mathrm{DV}}$ & $\underline{\text { Year }}$ & $\underline{\text { SOURCE }}$ & MEASURE & $\underline{\mathrm{MIN}}$ & $\underline{\mathrm{MAX}}$ & MEAN & $\underline{\text { STD DEV }}$ & $\underline{\mathrm{N}}$ \\
\hline Section 8 Units per 1000 persons & IV & $2000-2010$ & LMHA & \# & 1.2 & 73.2 & 24.0 & 16.4 & 86 \\
\hline Percentage of Vacant Units & IV & 2000 & Census & $\%$ & 2.2 & 20.0 & 7.7 & 4.6 & 86 \\
\hline Population & IV & 2000 & Census & \# & 1355 & 7278 & 3555 & 1318 & 86 \\
\hline Percentage of Non-White Residents & IV & 2000 & Census & $\%$ & 1.7 & 99.4 & 39.8 & 34.9 & 86 \\
\hline Miles to Nearest Superfund Site & IV & 2000 & LOJIC & mi. & 0.1 & 4.5 & 1.5 & 1.0 & 86 \\
\hline Tree Density per Person & IV & 2000 & LOJIC & $\#$ & 0.2 & 2.4 & 0.9 & 0.5 & 86 \\
\hline Percentage of Rental Units & IV & 2000 & JCPVA & $\%$ & 12.7 & 99.3 & 43.5 & 21.5 & 86 \\
\hline Total Number of Crimes per 100,000 & IV & 2004 & LMPD & \# & 4.4 & 16.6 & 7.6 & 3.7 & 86 \\
\hline Median Housing Age & IV & 2000 & Census & \# & 2 & 60 & 44.8 & 11.6 & 86 \\
\hline & & & & & & & & & \\
\hline Median Assessed Housing Value - 2006 & DV & 2006 & JCPVA & $\$$ & 8820 & 102685 & 71451 & 21328 & 84 \\
\hline
\end{tabular}

Notes: LMHA - Louisville Metro Housing Authority; US Census, 2000 Census; LOJIC - Louisville/Jefferson County Information Consortium; JCPVA: Jefferson County Property Valuation Administrator; LMPD -Louisville Metro Police Department. 
Table 4.20 Descriptives for Mean Assessed Value, 2008 - 50\% least expensive

\begin{tabular}{|c|c|c|c|c|c|c|c|c|c|}
\hline & $\underline{\mathrm{IV} / \mathrm{DV}}$ & $\underline{\text { Year }}$ & $\underline{\text { SOURCE }}$ & MEASURE & $\underline{\mathrm{MIN}}$ & $\underline{\text { MAX }}$ & $\underline{\text { MEAN }}$ & $\underline{\text { STD DEV }}$ & $\underline{\mathrm{N}}$ \\
\hline Section 8 Units per 1000 persons & IV & $2000-2010$ & LMHA & \# & 1.2 & 73.2 & 23.9 & 16.2 & 86 \\
\hline Percentage of Vacant Units & IV & 2000 & Census & $\%$ & 2.2 & 19.1 & 7.4 & 4.4 & 86 \\
\hline Population & IV & 2000 & Census & \# & 1355 & 7763 & 3665 & 1454 & 86 \\
\hline Percentage of Non-White Residents & IV & 2000 & Census & $\%$ & 1.7 & 99.4 & 39.1 & 35.1 & 86 \\
\hline Miles to Nearest Superfund Site & IV & 2000 & LOJIC & $\mathrm{mi}$. & 0.1 & 4.5 & 1.5 & 1.0 & 86 \\
\hline Tree Density per Person & IV & 2000 & LOJIC & $\#$ & 0.2 & 2.5 & 0.9 & 0.5 & 86 \\
\hline Percentage of Rental Units & IV & 2000 & JCPVA & $\%$ & 12.7 & 99.3 & 42.7 & 19.9 & 86 \\
\hline Total Number of Crimes per 100,000 & IV & 2004 & LMPD & \# & 4.4 & 16.6 & 7.4 & 3.5 & 86 \\
\hline Median Housing Age & IV & 2000 & Census & \# & 2 & 60 & 44.3 & 11.6 & 86 \\
\hline Median Assessed Housing Value - 2008 & DV & 2008 & JCPVA & $\$$ & 32030 & 109645 & 75942 & 22504 & 84 \\
\hline
\end{tabular}

Notes: LMHA - Louisville Metro Housing Authority; US Census, 2000 Census; LOJIC - Louisville/Jefferson County Information Consortium; JCPVA: Jefferson County Property Valuation Administrator; LMPD -Louisville Metro Police Department. 
Table 4.21 Descriptives for Mean Assessed Value, 2010 - 50\% least expensive

\begin{tabular}{|c|c|c|c|c|c|c|c|c|c|}
\hline & $\underline{\mathrm{IV} / \mathrm{DV}}$ & Year & $\underline{\text { SOURCE }}$ & MEASURE & $\underline{\mathrm{MIN}}$ & $\underline{\text { MAX }}$ & MEAN & $\underline{\text { STD DEV }}$ & $\underline{\mathrm{N}}$ \\
\hline Section 8 Units per 1000 persons & IV & $2000-2010$ & LMHA & \# & 1.2 & 73.2 & 24.0 & 16.3 & 85 \\
\hline Percentage of Vacant Units & IV & 2000 & Census & $\%$ & 2.2 & 19.1 & 7.5 & 4.4 & 85 \\
\hline Population & IV & 2000 & Census & \# & 1355 & 7763 & 3635 & 1436 & 85 \\
\hline Percentage of Non-White Residents & IV & 2000 & Census & $\%$ & 1.7 & 99.4 & 39.5 & 35.1 & 85 \\
\hline Miles to Nearest Superfund Site & IV & 2000 & LOJIC & mi. & 0.1 & 4.5 & 1.5 & 1.0 & 85 \\
\hline Tree Density per Person & IV & 2000 & LOJIC & \# & 0.2 & 2.5 & 0.9 & 0.5 & 85 \\
\hline Percentage of Rental Units & IV & 2000 & JCPVA & $\%$ & 12.7 & 99.3 & 42.8 & 20.0 & 85 \\
\hline Total Number of Crimes per 100,000 & IV & 2004 & LMPD & \# & 4.4 & 16.6 & 7.4 & 3.5 & 85 \\
\hline Median Housing Age & IV & 2000 & Census & \# & 2 & 60 & 44.5 & 11.6 & 85 \\
\hline & & & & & & & & & \\
\hline Median Assessed Housing Value - 2010 & DV & 2010 & JCPVA & $\$$ & 26375 & 109125 & 72489 & 26248 & 84 \\
\hline
\end{tabular}

Notes: LMHA - Louisville Metro Housing Authority; US Census, 2000 Census; LOJIC - Louisville/Jefferson County Information Consortium; JCPVA: Jefferson County Property Valuation Administrator; LMPD -Louisville Metro Police Department. 
Map 4.3 Mean Assessed Value Distribution, 2000 - 50/50

Map of Louisville / Jefferson County Showing the Distribution of Mean Assessed Value of Property Above and Below the Median Value of $\$ 80,227.50$ (2000)

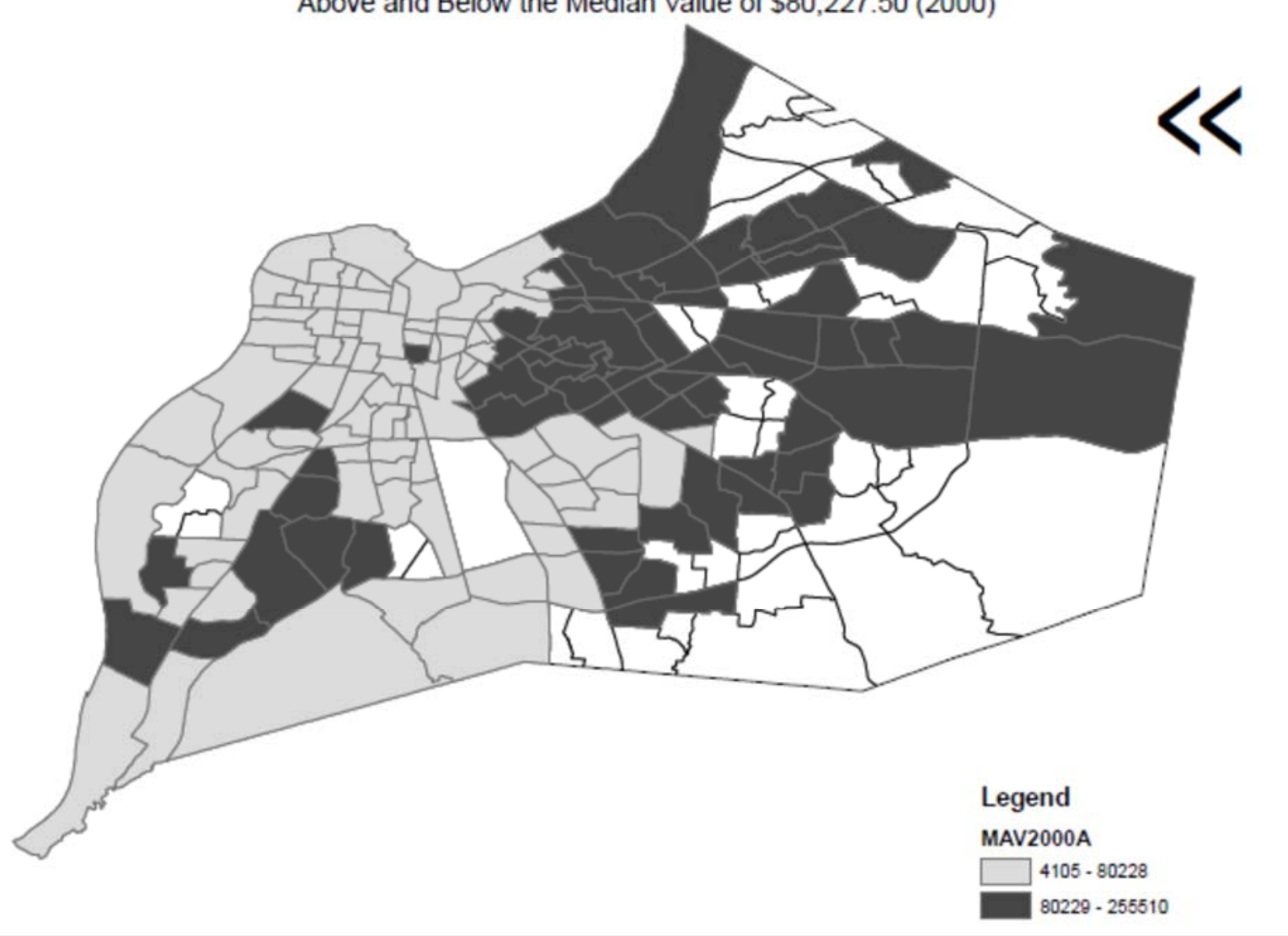


Map 4.4 Mean Assessed Value Distribution, 2006 - 50/50

Map of Louisville / Jefferson County Showing the Distribution of Mean Assessed Value of Property Above and Below the Median Value of $\$ 103,843$ (2006)

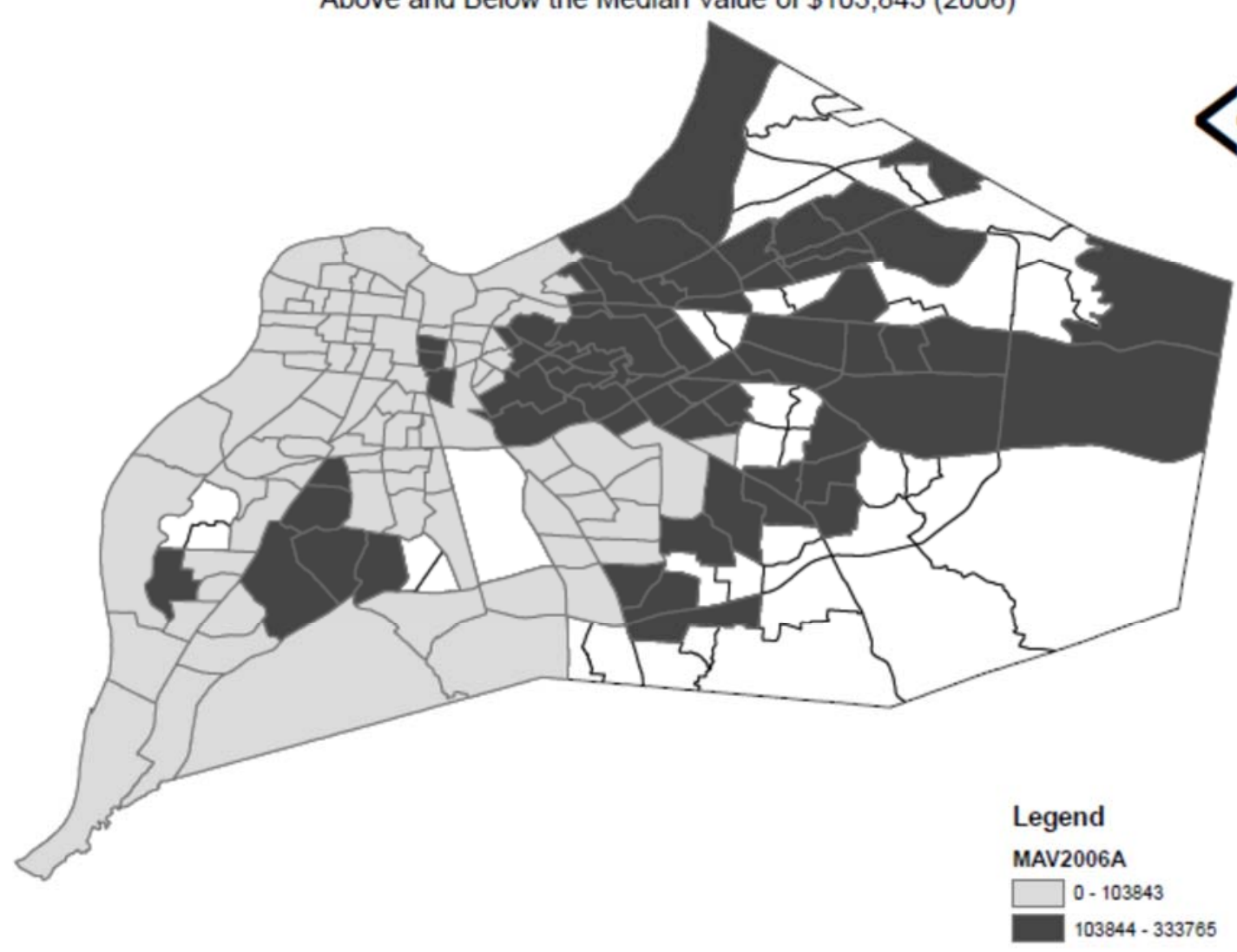


Map 4.5 Mean Assessed Value Distribution, 2008 - 50/50

Map of Louisville / Jefferson County Showing the Distribution of Mean Assessed Value of Property Above and Below the Median Value of $\$ 110,272$ (2008)

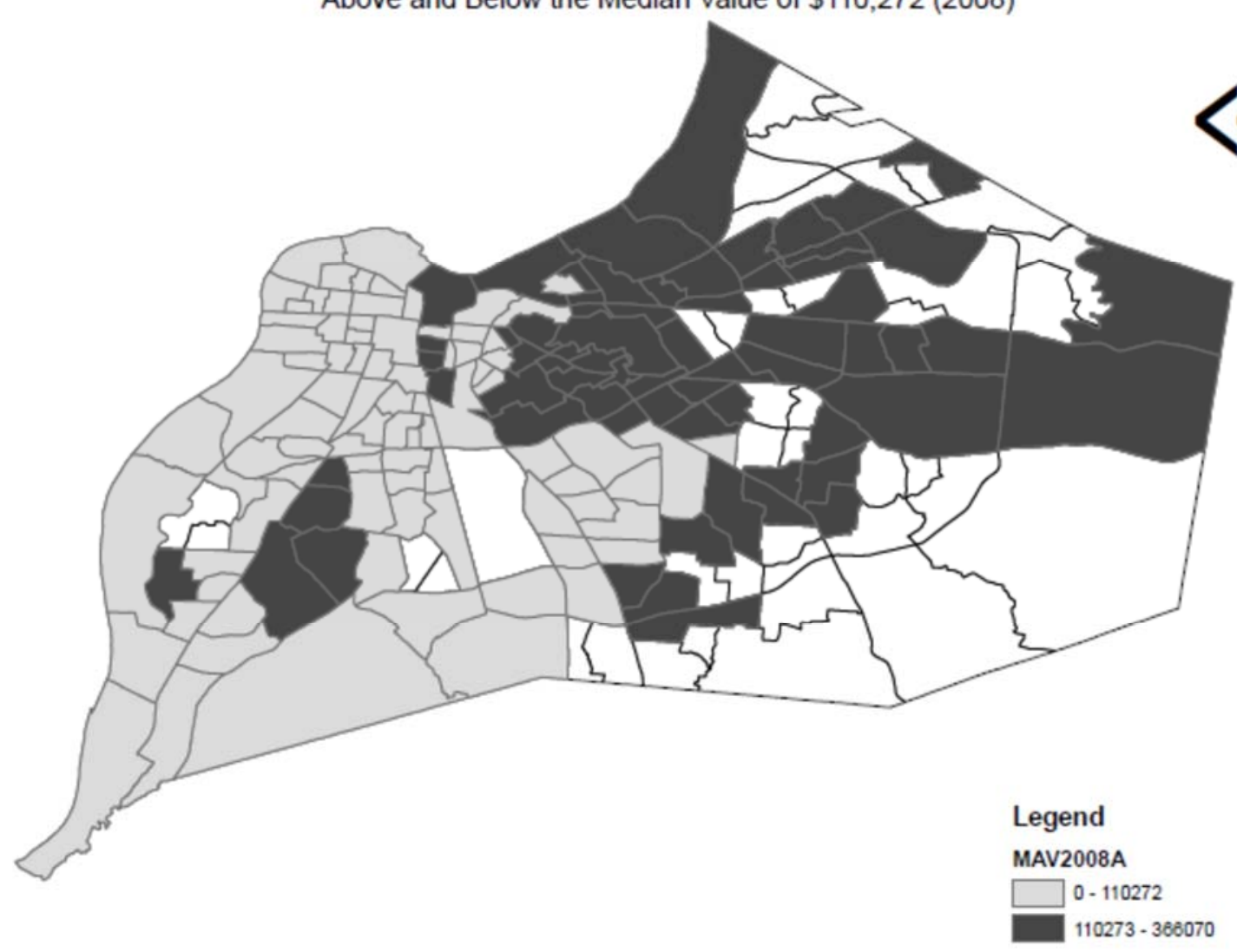


Map 4.6 Mean Assessed Value Distribution, 2010 - 50/50

Map of Louisville / Jefferson County Showing the Distribution of Mean Assessed Value of Property Above and Below the Median Value of $\$ 110,000$ (2010)

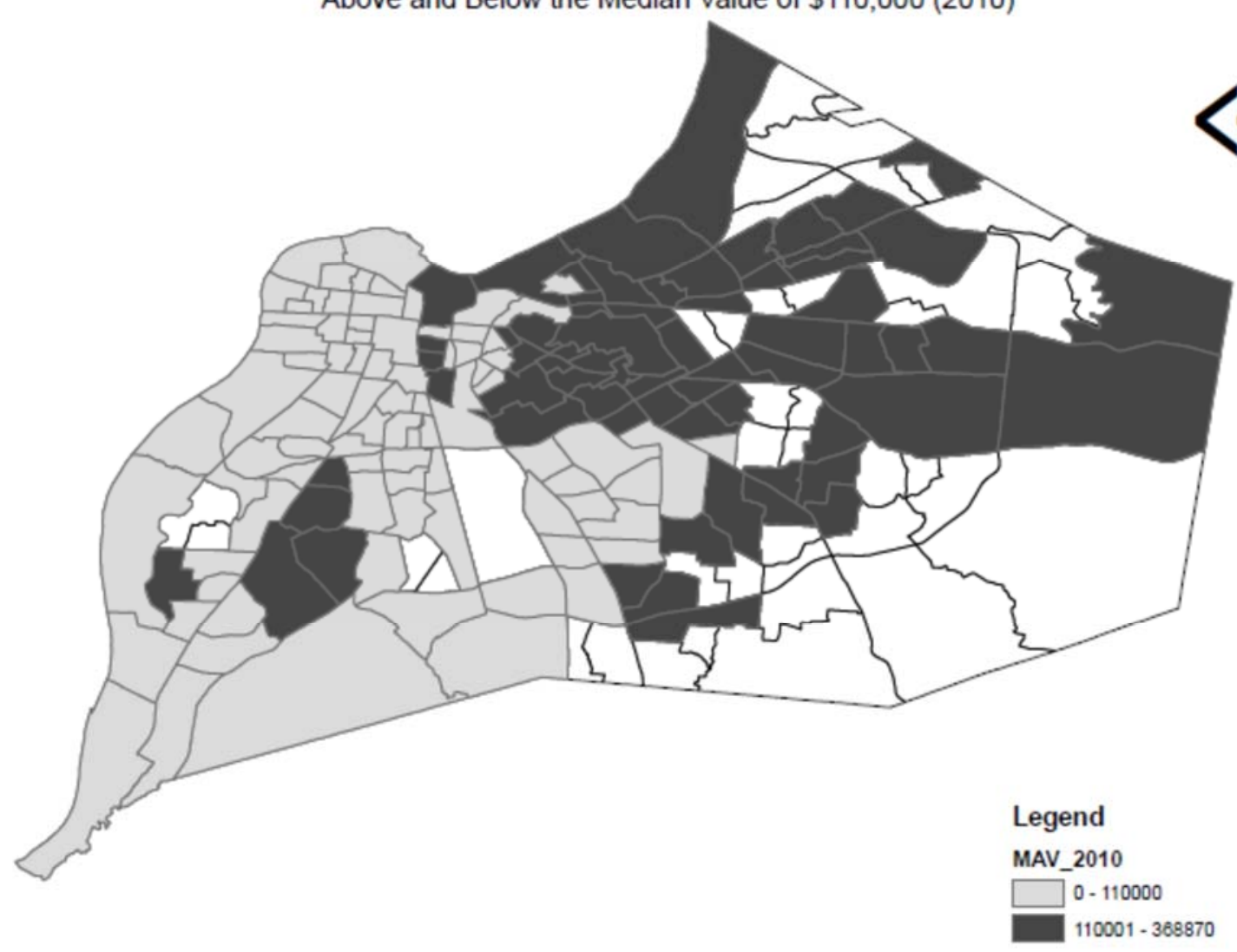




\section{Summary of the Results}

Analysis of the data set reveals that while there is the potential relationship between an increase in Section 8 housing units and changes in mean assessed housing values over time, this relationship is not statistically guaranteed. This relationship may be statistically significant in that in several regressions, as Section 8 housing density increases, mean assessed housing values decrease. However, when a split regression is performed by grouping census tracts by mean assessed valuations, the significance of the relationship falls outside of the probability of $p$ less than or equal to 0.05 . These mixed results show that the potential negative relationship between mean assessed values and Section 8 housing densities is not an open and shut case. 


\section{CHAPTER FIVE - QUALITATIVE SURVEY RESULTS}

While social science research can provide meaningful information to help guide policy development, there is also a qualitative component that is beneficial to a full understanding of the statistical information so that it is understood whether decisions driven by quantitative results fit with preconceived notions or not. There are urban legends related to the negative impacts of Section 8 housing on the surrounding communities, which do not stand up under regression analysis.

This research has shown mixed results on the issue of whether Section 8 housing correlates with and has a high probability of causing negative housing values in surrounding neighborhoods. The split regressions run to supplement the original evaluation, add nuance to these discoveries. In fact, there is a probability that there may be densities of Section 8 housing that result in lower probabilities of impact on adjacent housing values. Further regressions, however, showed that these results are not always significant.

In an attempt to provide additional information and background on the quantitative analysis, a qualitative study was designed to determine if the factual results seen in the regression analysis, are also observed by professionals that participate in rental operations on a daily basis.

Rather than arbitrarily selecting individual apartment communities and reaching out to individuals, the researcher contacted the Louisville Apartment Association (LAA). 
This organization represents over 48,000 apartment units in the greater Louisville area. The association is a local trade organization consisting of apartment owners, managers, and their suppliers. Its goal is to assist members in the efficient, professional operation of convenient, comfortable apartment living.

A membership directory was obtained, and a list of regular association members was created. Associate members were generally excluded from this study. To facilitate the efficient distribution of the survey, an online survey tool was used. The survey site is www.surveymonkey.com. Since this is an online survey, only regular members of the Association with listed e-mail addresses were included in the survey.

A total of 115 apartment managers and owners were identified as having email addresses. The survey questions listed earlier in the dissertation were sent to this sample in August 2016. Of the 115 electronic addresses obtained, nine were determined to be invalid addresses and were returned unanswered. This left 106 possible survey takers in my sample. After two weeks and two follow up reminders to participate, a total of 14 people responded, which is a response rate of $13.2 \%$. This is a non-representative sample; therefore conclusions from this information will not be valid, but generalizations may be made. Very little cooperation from landlords was received, but the results do shed some light on and affirm the quantitative results.

\section{Survey Summary}

The survey consisted of 20 questions. The first ten questions identified the attitudes of the survey responders with regard to the possible impact of Section 8 residents on surrounding house values. These questions were multiple-choice requiring 
the respondent to choose one of five answers. There were two levels of agreement, two levels of disagreement, and a no opinion/neutral choice. The next two questions were fillin-the-blank to gather information on the percent of Section 8 renters and on the number of apartments owned or managed by the responder. Questions to provide locational information within the city, and demographics of the responders, were also included. Lastly, the survey included an opportunity to provide a freeform answer on how the Section 8 rental system might be improved.

A summary of the anonymous individual responses follows. The survey responders either own or manage from two to 350 apartments, with an average of 138 apartment units. Eight of the 14 responders have Section 8 residents within their community with a range from zero to $30 \%$. The $30 \%$ may represent an outlier, as the next highest percentage of Section 8 residents was 15\%. All of the survey responders were White, ranging in age from 30 to 63 years of age.

When queried as to whether Section 8 housing densities would cause an increase or a decrease in surrounding property values, the results were clear. Over $64 \%$ believed that the presence of Section 8 residents would have a negative effect on surrounding values. When the density of Section 8 residents was defined as a large concentration, 93\% agreed with the premise. When asked about smaller concentrations, the range of answers was evenly split regarding the effect on nearby properties. An approximately equal number of responders projected positive or negative effects nearby. This is an important result, because the split regressions of the earlier chapter showed that smaller concentrations of Section 8 residents had less probability of impact on housing values. The overall opinion of survey responders agrees in principle with the quantitative results. 
The next series of questions was used to explore potential bias of the responders related to Section 8 residents. The results suggest minimal bias in that $93 \%$ of the responders either disagreed or were neutral regarding higher eviction rates among Section 8 residents, and the same percentage did not believe there were more problems associated with these residents. Generally speaking, the answers show that market rate residents and Section 8 residents behave similarly in this environment in the opinion of the responding landlords.

\section{Summary of the Open-ended Opinions}

The respondents were given an opportunity to provide their thoughts on this subject in a free form format. It should be repeated here, that these results and comments are not a representative sample and therefore any conclusions are speculation only.

When asked to provide ways in which the voucher system could be improved, the responses could be lumped into several large categories. These categories are as follows:

- Desire to help others

- The system

- The process

The verbatim statements are included below. These statements describe success stories, suggest need for general public education and identify abuse within the system.

"Better support in the office for voucher holders (my renter was a single mom that never got adopted out of foster care, she was in school, she had to work really hard to get her vouchers and she was not supported well in the office, often she reported staff were rude, 
long delays) and better education to the public about Section 8 so landlords and public in general understand how easy it is to accept the vouchers and the safeguards that are in place."

"There are a lot of very good tenants on that that I feel are really trying to roll off the program or at least make the best of the situation they are in, but for every one of those, there is at least 1 more who knows how to work the system with no intention more than free/discounted rent. I don't have a solution for how to police that situation, but something that would help might be a tenant review. When a tenant moves out and we have to sign the paper saying they are in good standings. It might be nice to add a couple questions about the quality of the tenant. Not that any one review should impact the tenant, but if there is a constant disapproval of the tenant. It may be time to give someone else on the waiting list a chance."

"Better regulation of the income of the residents. I believe too many abuse the program."

"Drug test and background check ones going on the section 8 program and when they renew their section 8 program."

"less bureaucracy"

"Increase subsidy to be more places where rents are higher"

"Make all aspects of the program, especially the eviction process, at least equal to the general housing market."

These comments will help to fashion the recommendations on the Section 8 voucher process in the conclusion. 
The general nature of the questions and the survey results provide further insight on the relationship between mean assessed values and Section 8 housing densities. Twothirds of respondents were either neutral or disagreed with the premise that the presence of Section 8 recipients causes increases in surrounding property values. When the term 'large concentrations' was added to the question, $100 \%$ were neutral or agreed that values would decrease. This is consistent with the quantitative results. Importantly, when the term 'small concentrations' was used, the result was evenly split between either a decrease or an increase of surrounding values. This provides some credence to the possibility that small doses of Section 8 may not harm assessed valuations in surrounding areas.

When asked about the general value of Section 8 residents, and the profit or problems associated with such residents, the range of answers was fairly evenly split between pros and cons. $100 \%$ of respondents were in agreement, however, that given a choice they would rather not have Section 8 residents on property. Contrary to this expressed concern was the response to the question about evictions or problems with Section 8 residents. Almost 100\% disagreed, or were neutral, that there are more evictions or problems related to Section 8 residents.

Following is a summary of survey response percentages, response count and a pie chart of results. 


\section{Attitudes related to Section 8 housing}

I believe that having Section 8 residents in a community increase surrounding housing values.

\section{Answer Options}

strongly disagree

disagree

no opinion/neutral

agree

strongly agree

$\begin{array}{ccc}\begin{array}{c}\text { Response } \\ \text { Percent }\end{array} & \begin{array}{c}\text { Response } \\ \text { Count }\end{array} \\ 14.3 \% & 2 & \\ 50.0 \% & 7 & \\ 7.1 \% & 1 & \\ 21.4 \% & 3 & \\ 7.1 \% & 1 & \\ \text { answered question } & & 14 \\ \text { skipped question } & & 0\end{array}$

I believe that having Section 8 residents in a community increase surrounding housing values.

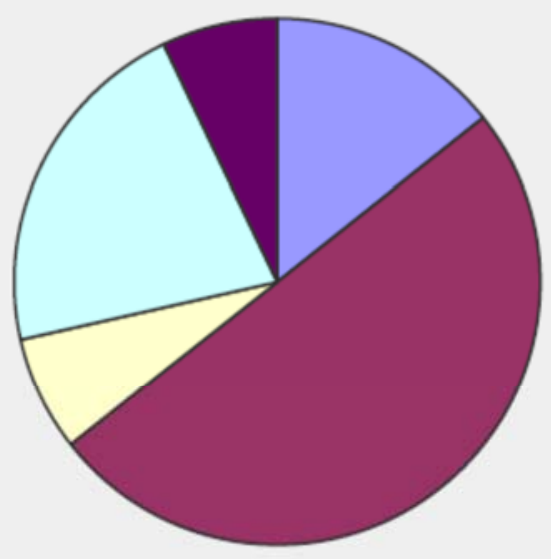

Qstrongly disagree

adisagree

口no opinion/neutral

口agree

astrongly agree 


\section{Attitudes related to Section 8 housing}

I believe that large concentrations of Section 8 housing recipients decrease surrounding housing values.

Answer Options

strongly disagree

disagree

no opinion/neutral

agree

strongly agree

$\begin{array}{ccc}\begin{array}{c}\text { Response } \\ \text { Percent }\end{array} & \begin{array}{c}\text { Response } \\ \text { Count }\end{array} \\ 0.0 \% & 0 & \\ 0.0 \% & 0 & \\ 7.1 \% & 1 & \\ 78.6 \% & 11 & \\ 14.3 \% & 2 & 14 \\ \text { red question } & & 14 \\ \text { ped question } & & 0\end{array}$

I believe that large concentrations of Section 8 housing recipients decrease surrounding housing values.

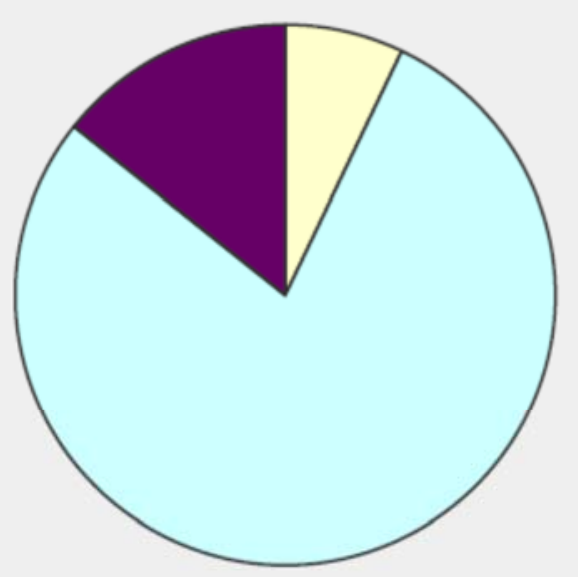

口strongly disagree

adisagree

Qno opinion/neutral

口agree

-strongly agree 


\section{Attitudes related to Section 8 housing}

I believe that small concentrations of Section 8 housing recipients decrease surrounding housing values.

\section{Answer Options}

strongly disagree

disagree

no opinion/neutral

agree

strongly agree

$\begin{array}{ccr}\begin{array}{c}\text { Response } \\ \text { Percent }\end{array} & \begin{array}{c}\text { Response } \\ \text { Count }\end{array} \\ 7.1 \% & 1 & \\ 28.6 \% & 4 & \\ 21.4 \% & 3 & \\ 42.9 \% & 6 & \\ 0.0 \% & 0 & 14 \\ \text { answered question } & & 0 \\ \text { skipped question } & & 0\end{array}$

I believe that small concentrations of Section 8 housing recipients decrease surrounding housing values.

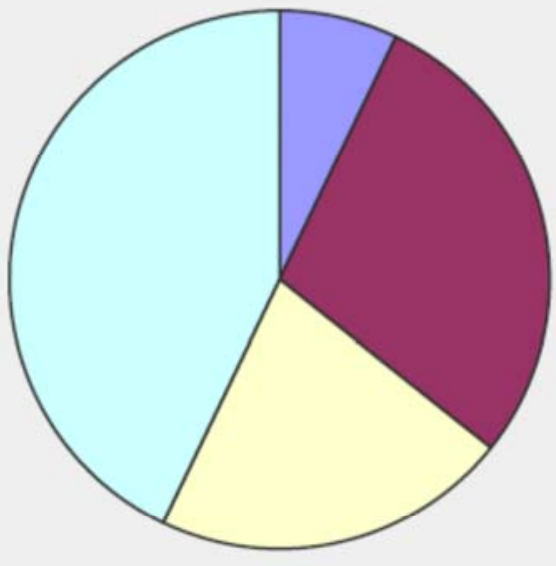

口strongly disagree

adisagree

םno opinion/neutral

口agree

Istrongly agree 


\section{Attitudes related to Section 8 housing}

I value having Section 8 housing recipients in my community.

\section{Answer Options}

strongly disagree

disagree

no opinion/neutral

agree

strongly agree

$\begin{array}{ccr}\begin{array}{c}\text { Response } \\ \text { Percent }\end{array} & \begin{array}{c}\text { Response } \\ \text { Count }\end{array} \\ 7.7 \% & 1 & \\ 23.1 \% & 3 & \\ 23.1 \% & 3 & \\ 30.8 \% & 4 & \\ 15.4 \% & 2 & 13 \\ \text { red question } & & 1\end{array}$

I value having Section 8 housing recipients in my community.

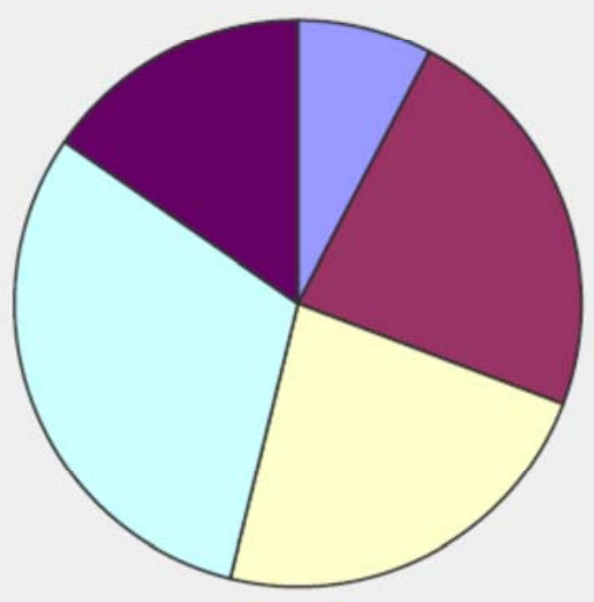

口strongly disagree

adisagree

ano opinion/neutral

口agree

Estrongly agree 


\section{Attitudes related to Section 8 housing}

Having Section 8 housing recipients in my community increase my profits.

$\begin{array}{lcc}\text { Answer Options } & \begin{array}{c}\text { Response } \\ \text { Percent }\end{array} & \begin{array}{c}\text { Response } \\ \text { Count }\end{array} \\ \text { strongly disagree } & 0.0 \% & 0 \\ \text { disagree } & 14.3 \% & 2 \\ \text { no opinion/neutral } & 50.0 \% & 7 \\ \text { agree } & 35.7 \% & 5 \\ \text { strongly agree } & 0.0 \% & 0 \\ & \text { answered question } & 14 \\ & \text { skipped question } & 0\end{array}$

Having Section 8 housing recipients in my community increase my profits.

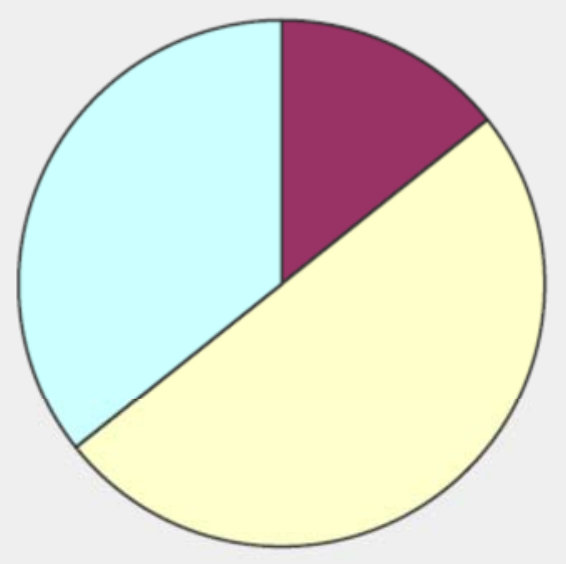

口strongly disagree

adisagree

口no opinion/neutral

aagree

mstrongly agree 


\section{Attitudes related to Section 8 housing}

Section 8 recipients cause more problems than the average market rate resident.

$\begin{array}{lcc}\text { Answer Options } & \begin{array}{c}\text { Response } \\ \text { Percent }\end{array} & \begin{array}{c}\text { Response } \\ \text { Count }\end{array} \\ \text { strongly disagree } & 7.1 \% & 1 \\ \text { disagree } & 42.9 \% & 6 \\ \text { no opinion/neutral } & 28.6 \% & 4 \\ \text { agree } & 7.1 \% & 1 \\ \text { strongly agree } & 14.3 \% & 2 \\ & \text { answered question } & 14 \\ & \text { skipped question } & 0\end{array}$

Section 8 recipients cause more problems than the average market rate resident.

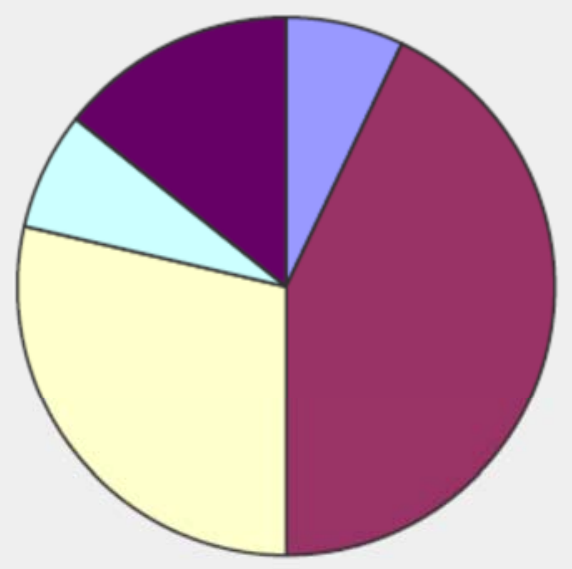

口strongly disagree

adisagree

口no opinion/neutral

Dagree

Estrongly agree 


\section{Attitudes related to Section 8 housing}

I prefer Section 8 residents over non-Section 8 residents on my property.

\begin{tabular}{|c|c|c|}
\hline Answer Options & $\begin{array}{c}\text { Response } \\
\text { Percent }\end{array}$ & $\begin{array}{c}\text { Response } \\
\text { Count }\end{array}$ \\
\hline strongly disagree & $7.1 \%$ & 1 \\
\hline disagree & $50.0 \%$ & 7 \\
\hline no opinion/neutral & $42.9 \%$ & 6 \\
\hline agree & $0.0 \%$ & 0 \\
\hline \multirow[t]{3}{*}{ strongly agree } & $0.0 \%$ & 0 \\
\hline & ered questio & 14 \\
\hline & oped questio & \\
\hline
\end{tabular}

I prefer Section 8 residents over non-Section 8 residents on my property.

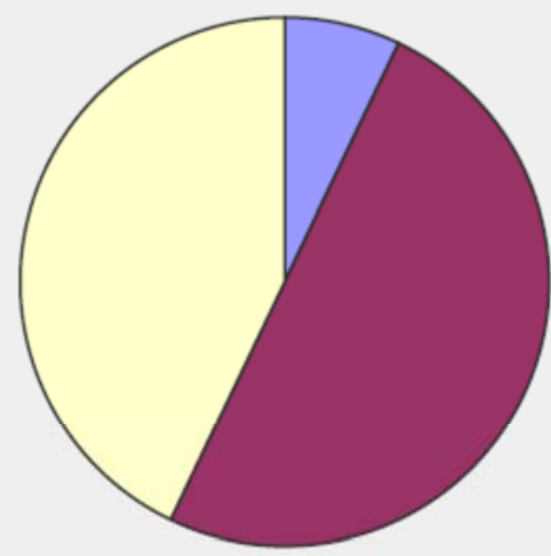

पstrongly disagree

adisagree

पno opinion/neutral

aagree

- astrongly agree 


\section{Attitudes related to Section 8 housing}

The Federal Government has an obligation to subsidize housing that is affordable.

\section{Answer Options}

strongly disagree

disagree

no opinion/neutral

agree

strongly agree

$\begin{array}{ccr}\begin{array}{c}\text { Response } \\ \text { Percent }\end{array} & \begin{array}{c}\text { Response } \\ \text { Count }\end{array} \\ 14.3 \% & 2 & \\ 28.6 \% & 4 & \\ 28.6 \% & 4 & \\ 21.4 \% & 3 & \\ 7.1 \% & 1 & 14 \\ \text { ered question } & & 14 \\ & & 0\end{array}$

The Federal Government has an obligation to subsidize housing that is affordable.

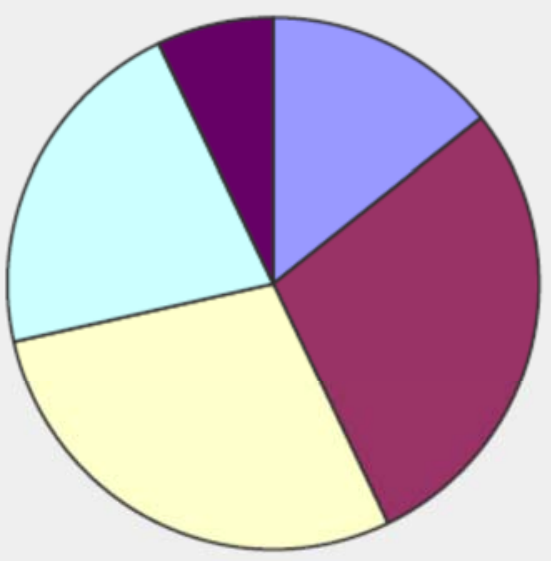

口strongly disagree

adisagree

口no opinion/neutral

Dagree

- strongly agree 
Attitudes related to Section 8 housing

I evict more Section 8 residents than non-Section 8 residents.

Answer Options

strongly disagree

disagree

no opinion/neutral

agree

strongly agree

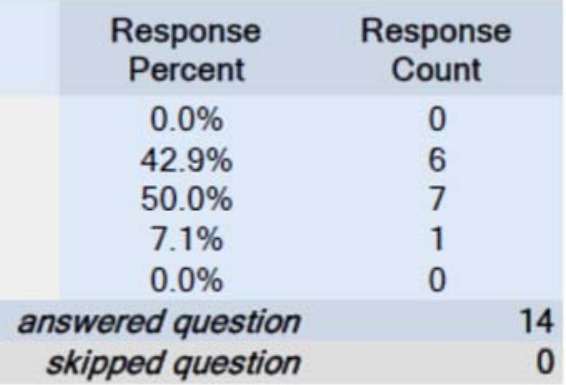

I evict more Section 8 residents than non-Section 8 residents.

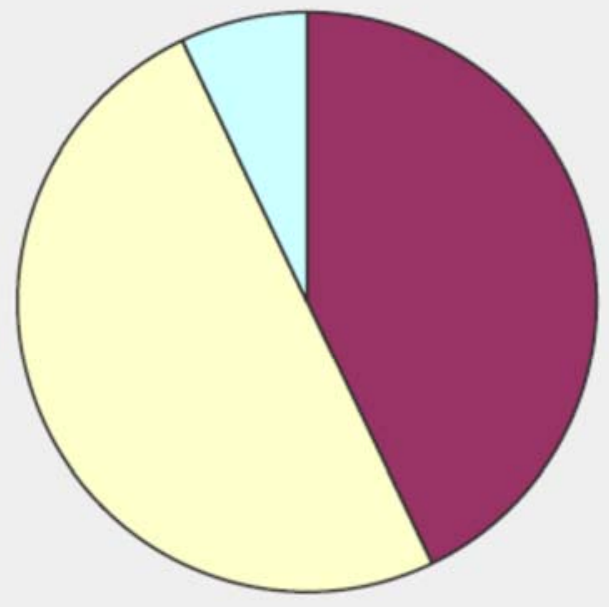

口strongly disagree

adisagree

口no opinion/neutral

aagree

- strongly agree 


\section{Attitudes related to Section 8 housing}

I have more problems with Section 8 residents than non-Section 8 residents.

\begin{tabular}{l|cc} 
Answer Options & Response & Response \\
& Percent & Count \\
strongly disagree & $7.1 \%$ & 1 \\
disagree & $35.7 \%$ & 5 \\
no opinion/neutral & $57.1 \%$ & 8 \\
agree & $0.0 \%$ & 0 \\
strongly agree & $0.0 \%$ & 0 \\
& answered question & 14 \\
& skipped question & 0
\end{tabular}

I have more problems with Section 8 residents than non-Section 8 residents.

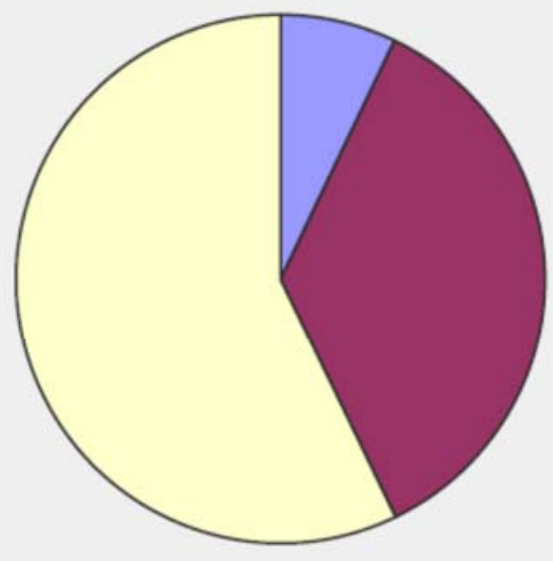

口strongly disagree

चdisagree

口no opinion/neutral

Dagree

- strongly agree 


\section{Attitudes related to Section 8 housing}

What percent of your renters are Section 8 housing recipients?

Answer Options

Response

Count

13

9/6/2016 12:41 PM View respondent's answers

zero

9/3/2016 1:07 PM View respondent's answers

9/3/2016 11:16 AM View respondent's answers

$\underline{9 / 3 / 2016 \text { 10:43 AM View respondent's answers }}$

$\underline{8 / 30 / 201610: 14 \text { AM View respondent's answers }}$

8/29/2016 4:33 PM View respondent's answers

8/29/2016 4:16 PM View respondent's answers

8/29/2016 4:14 PM View respondent's answers

$\underline{\text { 8/29/2016 12:41 PM View respondent's answers }}$

8/24/2016 3:06 PM View respondent's answers

$\underline{\text { 8/23/2016 10:48 AM View respondent's answers }}$

$\underline{\text { 8/23/2016 10:27 AM View respondent's answers }}$

None at the present time $\underline{\text { 8/23/2016 10:26 AM View respondent's answers }}$ 


\section{Attitudes related to Section 8 housing}

How many apartments do you own or operate?
\begin{tabular}{l|rr} 
Answer Options & $\begin{array}{c}\text { Response } \\
\text { Count }\end{array}$ \\
& 13 & 13 \\
& answered question & 13 \\
skipped question & 1
\end{tabular}

$\underline{\text { 9/6/2016 12:41 PM View respondent's answers }}$

9/3/2016 1:07 PM View respondent's answers

9/3/2016 11:16 AM View respondent's answers

$\underline{9 / 3 / 2016 \text { 10:43 AM View respondent's answers }}$

$\underline{\text { 8/30/2016 10:14 AM View respondent's answers }}$

8/29/2016 4:33 PM View respondent's answers

8/29/2016 4:16 PM View respondent's answers

8/29/2016 4:14 PM View respondent's answers

$\underline{\text { 8/29/2016 12:41 PM View respondent's answers }}$

8/24/2016 3:06 PM View respondent's answers

8/23/2016 10:48 AM View respondent's answers

$\underline{8 / 23 / 2016 ~ 10: 27 \text { AM View respondent's answers }}$

$\underline{8 / 23 / 2016 ~ 10: 26 \text { AM View respondent's answers }}$ 


\section{Attitudes related to Section 8 housing}

There should be no regulation of short term rentals like Air BNB.

$\begin{array}{lcc}\text { Answer Options } & \begin{array}{c}\text { Response } \\ \text { Percent }\end{array} & \begin{array}{c}\text { Response } \\ \text { Count }\end{array} \\ \text { strongly disagree } & 16.7 \% & 2 \\ \text { disagree } & 16.7 \% & 2 \\ \text { no opinion/neutral } & 16.7 \% & 2 \\ \text { agree } & 50.0 \% & 6 \\ \text { strongly agree } & 0.0 \% & 0 \\ & \text { answered question } & 12 \\ & \text { skipped question } & 2\end{array}$

There should be no regulation of short term rentals like Air BNB.

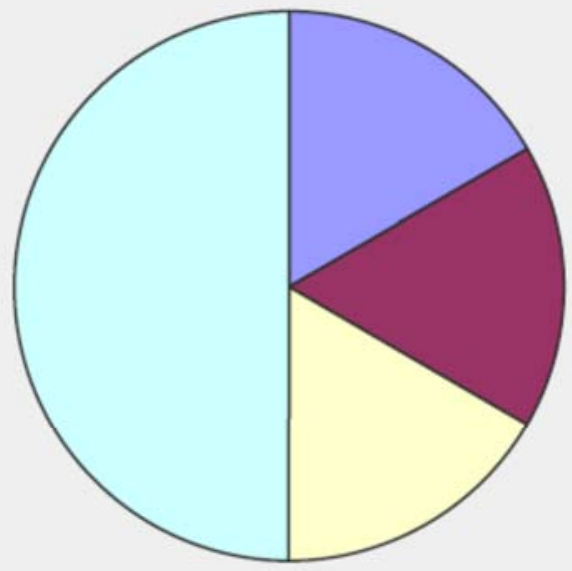

口strongly disagree

adisagree

口no opinion/neutral

aagree

astrongly agree 


\section{Attitudes related to Section 8 housing}

Short term rentals like Air BNB increase the neighborhood housing values.

\section{Answer Options}

strongly disagree

disagree

no opinion/neutral

agree

strongly agree
Response

Percent

$0.0 \%$

$36.4 \%$

$63.6 \%$

$0.0 \%$

$0.0 \%$

answered question

skipped question
Response

Count

0

4

7

0

0

Short term rentals like Air BNB increase the neighborhood housing values.

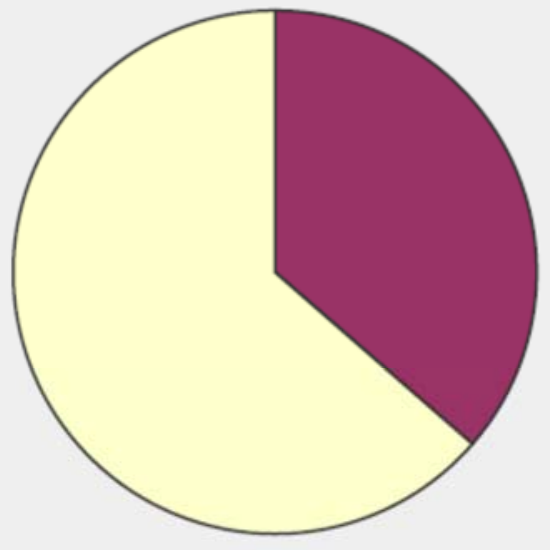

口strongly disagree

adisagree

口no opinion/neutral

Dagree

- strongly agree 


\section{Attitudes related to Section 8 housing}

Please enter the nearest major cross streets to your property.

Answer Options

Response

Count

13

answered question

East Burnett Ave and Shelby Street

9/3/2016 1:07 PM View respondent's answers

Hepburn and Barrett

9/3/2016 11:16 AM View respondent's answers

3ed and Hill

9/3/2016 10:43 AM View respondent's answers

Dixie Hwy

$\underline{\text { 8/30/2016 10:14 AM View respondent's answers }}$

Dixie Highway (us60)

8/29/2016 4:33 PM View respondent's answers

Dixie hwy

8/29/2016 4:16 PM View respondent's answers

Payne and Clifton

8/29/2016 4:14 PM View respondent's answers

3rd st. Near Kroger and Waterson

$\underline{\text { 8/29/2016 12:41 PM View respondent's answers }}$

Old shepherdsville

8/24/2016 3:06 PM View respondent's answers

Shelbyville Road

$\underline{\text { 8/23/2016 10:48 AM View respondent's answers }}$

Dixie and West Pages

$\underline{\text { 8/23/2016 10:27 AM View respondent's answers }}$

Cherokee and Grinstead 


\section{Attitudes related to Section 8 housing}

\section{What is your age?}

Answer Options

Response

Count

12

answered question

skipped question

9/3/2016 1:07 PM View respondent's answers

60

9/3/2016 11:16 AM View respondent's answers

9/3/2016 10:43 AM View respondent's answers

$\underline{8 / 30 / 2016 \text { 10:14 AM View respondent's answers }}$

8/29/2016 4:33 PM View respondent's answers

8/29/2016 4:16 PM View respondent's answers

8/29/2016 4:14 PM View respondent's answers

$\underline{\text { 8/29/2016 12:41 PM View respondent's answers }}$

8/24/2016 3:06 PM View respondent's answers

$\underline{\text { 8/23/2016 10:48 AM View respondent's answers }}$

$\underline{8 / 23 / 2016 ~ 10: 27 \text { AM View respondent's answers }}$ 


\title{
Attitudes related to Section 8 housing
}

How do you identify your gender?

Answer Options

Response

Count

13

answered question

\author{
female \\ 9/6/2016 12:41 PM View respondent's answers \\ Female \\ 9/3/2016 1:07 PM View respondent's answers \\ Female \\ 9/3/2016 11:16 AM View respondent's answers \\ $\mathrm{m}$ \\ 9/3/2016 10:43 AM View respondent's answers \\ Female \\ $\underline{\text { 8/30/2016 10:14 AM View respondent's answers }}$ \\ female \\ 8/29/2016 4:33 PM View respondent's answers \\ male \\ 8/29/2016 4:16 PM View respondent's answers \\ $\mathrm{F}$ \\ 8/29/2016 4:14 PM View respondent's answers \\ Male \\ 8/29/2016 12:41 PM View respondent's answers \\ Female \\ 8/24/2016 3:06 PM View respondent's answers \\ Male \\ $\underline{\text { 8/23/2016 10:48 AM View respondent's answers }}$ \\ male \\ $\underline{\text { 8/23/2016 10:27 AM View respondent's answers }}$ \\ Female \\ 8/23/2016 10:26 AM View respondent's answers
}




\section{Attitudes related to Section 8 housing}

How would you describe your race/ethnicity?

Answer Options

Response

Count

13

white american

9/6/2016 12:41 PM View respondent's answers

Caucasian

9/3/2016 1:07 PM View respondent's answers

Mulatto, primarily white

9/3/2016 11:16 AM View respondent's answers

white

9/3/2016 10:43 AM View respondent's answers

White

$\underline{\text { 8/30/2016 10:14 AM View respondent's answers }}$

italian

$\underline{\text { 8/29/2016 4:33 PM View respondent's answers }}$

white

8/29/2016 4:16 PM View respondent's answers

White European descent

$\underline{\text { 8/29/2016 4:14 PM View respondent's answers }}$

White

8/29/2016 12:41 PM View respondent's answers

White

8/24/2016 3:06 PM View respondent's answers

White

$\underline{8 / 23 / 2016 ~ 10: 48 \text { AM View respondent's answers }}$

white

$\underline{\text { 8/23/2016 10:27 AM View respondent's answers }}$

White

$\underline{\text { 8/23/2016 10:26 AM View respondent's answers }}$ 
This survey as stated earlier is just the start of what could be a qualitative project that may be used to assess attitudes on Section 8 housing residents by the providers of the housing. The case is not open and shut due to this survey, rather it has just been opened and the results are mixed. The conventional wisdom that Section 8 housing recipients cause all sorts of problems appears to not be true as these questions have shown that Section 8 residents are not seen as burdensome or problematic when compared to market rate residents.

It should be noted that this survey was fully vetted and approved by the University of Louisville Human Subjects Program Protection Office. The Institutional Review Board (IRB) approved this survey on the study of behavior and attitudes of individuals related to the above questions. A copy of the approval correspondence from the IRB is in the Appendix. 


\section{CHAPTER SIX - CONCLUSION AND DISCUSSION}

This chapter will revisit the theories and hypotheses laid out in chapters 2 and 3 in light of the findings from data analysis. An evaluation such as this was very much tied to a highly discussed article written in 2008 by Hanna Rosin published in The Atlantic magazine (Rosin, 2008). This article brought to a head the debate which has been going on for several decades related to whether or not Section 8 vouchers should be used. In an unscientific subjective article, Rosin tied crime increases in Memphis, Tennessee to Section 8 rental locations. The article attempted to identify the percent of low income residents within an area at which a tipping point occurs and crime explodes. The case is made that Section 8 recipients may move too quickly to a new neighborhood without analyzing the situation, and thus could not successfully adapt to the new environment away from their previous high poverty areas. What this article neglected to address is that deeply rooted poverty and social dysfunction exist in almost every American city and there is not a plan to address these concerns if the voucher program is stopped.

Rosin made incorrect statements related to the housing choice voucher program. Rosin made it seem as though participants were not free to locate in any given area and were required to move to subsidized housing projects. In reality, a family that is issued a housing voucher is free to choose any housing that meets the requirements of the program as long as the rental unit meets minimum standards of health and safety. It does not seem to be well known in non-academic literature that the choice of housing is in the hands of 
each individual family. When a family receives a housing voucher, then they may select a unit where the rent is below or above the payment standard. The family still must pay $30 \%$ of their monthly adjusted gross income for rent and utilities, while the balance is covered by the voucher. The process is very similar to normal market-rate rentals in that leases are signed and the families are allowed to move without the loss of housing assistance as long as they comply with the language of the lease. A very important component of the system is that if a person or family fail to follow the Section 8 housing rules, then rental assistance may be lost. At the same time, landlords are required to provide decent, safe, and sanitary housing at reasonable rent rates.

With these facts in mind, the results of this study need to be analyzed and put in the context of the hypotheses laid out for this study. The dependent variable - mean assessed value for the years 2000, 2006, 2008, and 2010 - was measured by utilizing the Louisville Metro property valuation system. The results from model number one which was utilized to evaluate the hypothesis number one, H1, was confirmed. Over the four years evaluated in this study, the mean assessed value in each of the four years was negatively impacted by increased levels of Section 8 housing within each census tract at a very high level of significance, $p$ less than or equal to .001 . Not only was this relationship significant, but study of the standardized beta revealed that the number of Section 8 housing units in each census tract was responsible for decreases in mean assessed neighborhood values within that same census tract.

Secondly, hypothesis number two, $\mathrm{H} 2$, sought to understand whether the impacts of section 8 housing on assessed valuations would change under differing economic conditions. The hypothesis suggested that during good economic times there would be a 
greater impact on assessed valuation then during a recessionary period. This hypothesis was not confirmed. The mean assessed value over time for the good economic period from 2000 to 2006 was not meaningfully different from the mean assessed value over time during the 2008 to 2010 per session.

Given these results, it was determined that further study was necessary. The question could logically arise as to which of these two variables, mean assessed valuation or Section 8 housing density, was driving the relationship. To assess and answer this question, the use of split regression models was determined to be a good option. The detailed techniques used for the split regression were described in chapter 4 . The ensuing regressions were split based upon either very high or low density of Section 8 units within the census tracts. These regressions in almost every instance yielded the maximum level of significance, $\mathrm{p}$ less other equal to .001 . The next regressions were also performed as a split regression, but instead of breaking the density of section 8 units at the $50 \%$ point, the split was performed at the $75 / 25$ point where one model represented $75 \%$ of the most dense Section 8 housing census tracts and the other represented the $25 \%$ least dense Section 8 housing tracts. In the case of this regression, it was not surprising that there was a high significance of a negative impact on mean assessed values in the $75 \%$ most dense section 8 census tracts. The least dense $25 \%$ of section 8 housing areas yielded different results. In three of the four cases the significance was at the lowest level measured, that is $\mathrm{p}$ less than or equal to .05 . The percentages of change that section 8 has on housing valuation were slightly less than in the previous model.

The results were starting to look like a closed case where mean assessed values are at a high statistical chance of being affected negatively by Section 8 housing nearby. 
However, another regression was split into the most expensive areas of town and the least expensive areas of town utilizing the mean assessed valuation to drive the split. In this regression, only one case out of eight showed any significance beyond the .05 level of probability. In the most expensive of the census tracts, the effect of the number of vacant units in the census tract and the number of rental units in the census tract both showed high levels of significance in a negative way with mean assessed values. This is a very understandable result in that nearby property values are generally known to react negatively to these two variables. The fact that Section 8 housing density showed no significance $(\mathrm{p}<=.05)$ with mean assessed values is definitely a mixed result from the earlier regressions.

While designed to de-concentrate poverty and spread public housing throughout a community the Housing Voucher System as implemented through the Section 8 housing program appears to have mixed results confirmed through quantitative research. This study reveals that as public assisted housing is spread throughout a community, an associated decline in the assessed valuation of neighborhoods has a high probability of occurrence, but is not significantly probable when evaluating wealthier neighborhoods. This in no way diminishes the fact that these policies significantly improve the lives of the urban poor in terms of education and self-esteem. The negative impact however cannot ignored as the public which supports these programs through the payment of taxes may be legitimately concerned related to the loss of value of property they own.

This evaluation cannot address the balance between the positive and negative attributes of the program. Since Section 8 is not an entitlement program, and qualification does not guarantee assistance, it is uncertain as to who is actually receiving the benefits 
and where they may be moving to within the city. This analysis did not look at who moved or where they moved to. Were these moves short moves? Are the minorities that moved still in minority areas? Since these items were not looked into, a further study to look at the location choices of individuals who receive these vouchers may be necessary.

It is unknown whether the net effect of the test variable on mean assessed values has a methodological or statistical issue that results in mixed outcomes. Future analyses could try to resolve this dilemma. Given the current data set, further study could look into where Section 8 voucher recipients started, and which neighborhoods they later located to. The question can become whether these voucher holders are more likely to move to neighborhoods that are poor or have similar demographic populations. The measurement of the effects on a given neighborhood's housing market that receives large and/or small numbers of actual recipients can be evaluated through the use of other variables as well such as foreclosures and/or housing code violations.

This study used advanced multiple regression techniques to study 170 Louisville neighborhoods to look at whether large concentrations of Section 8 housing has a negative impact on neighborhood housing values. It was found that large concentrations of Section 8 depress neighborhood values in poor neighborhoods even more, but Section 8 does not diminish the value in wealthy neighborhoods. This was done by using a split regression analysis. Additional research was carried out by interviewing landlords on attitudes toward Section 8 . It turns out that their views were mixed. Finally, research techniques were done using GIS mapping techniques to see how Section 8 is concentrated in mostly poor and minority neighborhoods. 
This is a study of one city in the United States. This study could be replicated in cities similar to Louisville, Kentucky to determine if these findings can be found at other locations as well. Further research is needed to determine the unknown factors that cause the results to be mixed. 


\section{REFERENCES}

Ambrosius, J. D., Gilderbloom, J. I., \& Hanka, M. J. (2010). Back to Black . . . and Green? Location and policy interventions in contemporary neighborhood housing markets. Housing Policy Debate, 20(3), 457-484.

Anthony, J. (2005). Family Self-Sufficiency Programs: An Evaluation of Program Benefits and Factors Affecting Participants' Success. Urban Affairs Review, 41(1), 65-92.

Appelbaum, R. P. (1976). The Effects of urban growth : a population impact analysis. New York : Praeger.

Brooks, F., Zugazaga, C., Wolk, J., \& Adams, M. A. (2005). Resident Perceptions of Housing, Neighborhood, and Economic Conditions after Relocation from Public Housing Undergoing HOPE VI Redevelopment. Research on Social Work Practice, 15(6), 481-490.

Burns, N. (1994). The Formation of American Local Governments : private values in public institutions. New York: Oxford University Press.

Chaskin, R. J., \& Joseph, M. L. (2013). 'Positive' Gentrification, Social Control and the 'Right to the City' in Mixed-Income Communities: Uses and Expectations of Space and Place. International Journal of Urban and Regional Research, 37(2), 480-502.

Checkoway, B. (1994). Paul Davidoff and Advocacy Planning in Retrospect. Journal of the American Planning Association, 60(2), 139-143.

Donnelly, P. G., \& Kimble, C. E. (1997). Community Organizing, Environmental Change, and Neighborhood Crime. Crime and Deliquency, 43(4), 493-511.

Downs, A. (1994). New Visions For Metropolitan America. Washington, D.C. Cambridge, Mass.: Brookings Institution ; Lincoln Institute of Land Policy.

Dreier, P., Mollenkopf, J. H., \& Swanstrom, T. (2001). Place Matters : metropolitics for the twenty-first century. Lawrence: University Press of Kansas. 
Dreier, P., Mollenkopf, J. H., \& Swanstrom, T. (2004). Place Matters : metropolitics for the twenty-first century (2nd ed.). Lawrence, Kan.: University Press of Kansas.

Duany, A., Plater-Zyberk, E., \& Speck, J. (2000). Suburban Nation : The rise of sprawl and the decline of the American Dream (1st ed.). New York: North Point Press.

Ellen, I. G., \& Turner, M. A. (1997). Does Neighborhood Matter? Assessing recent evidence. Housing Policy Debate, 8(4), 833-866.

Fainstein, S. S., \& Campbell, S. (2002). Readings in Urban Theory (2nd ed. ed.). Oxford, UK ;: Blackwell Publishers.

Forester, J. (1989). Planning in the Face of Power. Berkeley: University of California Press.

Freeman, L., \& Botein, H. (2002). Subsidized Housing and Neighborhood Impacts: A Theoretical Discussion and Review of the Evidence. Journal of Planning Literature, 16(3), 359-378.

Friedland, R. (1983). Power and Crisis in the City : Corporations, unions, and urban policy (1st American ed.). New York : Schocken Books

Galster, G. C., \& Mikelsons, M. (1995). The Geography of Metropolitan Opportunity: A case study of neighborhood conditions confronting youth in Washington, DC. Housing Policy Debate, 6(1), 73-102.

Gilderbloom, J. I., Ambrosius, J. D., Squires, G. D., Hanka, M. J., \& Kenitzer, Z. E. (2012). Investors: The Missing Piece in the Foreclosure Racial Gap Debate. Journal of Urban Affairs, 34(5), 559-582.

Gilderbloom, J. I., \& Appelbaum, R. P. (1988). Rethinking Rental Housing. Philadelphia : Temple University Press.

Gilderbloom, J. I., Hanka, M. J., \& Ambrosius, J. D. (2012). Without Bias? Government Policy That Creates Fair and Equitable Property Tax Assessments. American Review of Public Administration, 42(5), 591-605.

Gilderbloom, J. I., Riggs, W. W., \& Meares, W. L. (2015). Does Walkability Matter? An examination of walkability's impact on housing values, foreclosures and crime. Cities, 42(Part A), 13-24.

Goetz, E. G. (2003). Clearing the Way: deconcentrating the poor in urban America. Washington, D.C. : Urban Institute Press. 
Hanka, M. J., Gilderbloom, J. I., Meares, W. L., Khan, M., \& Wresinski, K. E. (2015). Measuring Job Creation for HOPE VI: A success story for community development efforts. Community Development, 46(2), 133-148.

Imbroscio, D. L. (2010). Urban America Reconsidered : Alternatives for governance and policy. Ithaca : Cornell University Press.

Jacobs, J. (1961). The Death and Life of Great American Cities. New York :: Random House.

Kelly, J. M., \& Adhikari, S. (2013). Indicators of Financial Condition in Pre- and PostMerger Louisville. Journal of Urban Affairs, 35(5), 553-567.

Krumholz, N. (1999). Equitable Approaches to Local Economic Development. Policy Studies Journal, 27(1), 83-95.

Leinberger, C. B. (2008). The Option of Urbanism : Investing in a new American dream. Washington, DC :: Island Press.

Logan, J. R., \& Molotch, H. L. (1987). Urban Fortunes : The political economy of place. Berkeley, CA :: University of California Press.

Massey, D. S., \& Denton, N. A. (1993). American Apartheid : Segregation and the making of the underclass. Cambridge, Mass.: Harvard University Press.

Molotch, H. (1976). Varieties of Growth Strategy: Some Comments on Logan. American Journal of Sociology, 82(2), 352-355.

Oates, W. E. (1999). An Essay on Fiscal Federalism. Journal of Economic Literature, $37(3)$.

Ostrom, E. (2000). Collective Action and the Evolution of Social Norms. The Journal of Economic Perspectives, 14(3), 137-158.

Ostrom, V., \& Ostrom, E. (1971). Public Choice: A Different Approach to the Study of Public Administration. Public Administration Review, 31(2), 203-216.

Popkin, S. J., Buron, L. F., Levy, D. K., \& Cunningham, M. K. (2000). The Gautreaux Legacy: What Might Mixed-Income and Dispersal Strategies Mean for the Poorest Public Housing Tenants? Housing Policy Debate, 11(4), 911-942.

Rosenbaum, J. E., \& Deluca, S. (2008). What Kinds of Neighborhoods Change Lives? The Chicago Gautreaux Housing Program and Recent Mobility Programs. Indiana Law Review, 41(3). 
Rosenbaum, J. E., Reynolds, L., \& Deluca, S. (2002). How Do Places Matter? The Geography of Opportunity, Self-efficacy and a Look Inside the Black Box of Residential Mobility. Housing studies., 17, 71-82.

Rosin, H. (2008). American Murder Mystery What's behind the spike in crime? Atlantic Monthly, 302(1), 40-55.

Sampson, R. J. (2012). Great American City : Chicago and the enduring neighborhood effect. Chicago ; The University of Chicago Press.

Savitch, H. V., \& Vogel, R. K. (2004). Suburbs without a City: Power and City-County Consolidation. Urban Affairs Review, 39(6), 758-790.

Schweigert, F. J. (2006). The Meaning of Effectiveness in Assessing Community Initiatives. American Journal of Evaluation, 27(4), 416-436.

Song, W., \& Keeling, K. (2010). Location Patterns of Section 8 Housing in Jefferson County, Kentucky. International Journal of Applied Geospatial Research, 1(2), 118.

Stone, C. N. (1989). Regime Politics : Governing Atlanta, 1946-1988. Lawrence, Kan.: University Press of Kansas.

Suresh, G., \& Vito, G. (2009). Homicide Patterns and Public Housing: The Case of Louisville, KY (1989-2007). Homicide Studies, 13(4), 411-433.

Swanstrom, T., Dreier, P., \& Mollenkopf, J. (2002). Economic Inequality and Public Policy: The Power of Place. City \& Community, 1(4), 349-372.

Talen, E., \& Koschinsky, J. (2014). The Neighborhood Quality of Subsidized Housing. Journal of the American Planning Association, 80(1), 67-82.

Tiebout, C. M. (1956). A Pure Theory of Local Expenditures. Journal of Political Economy, 64(5), 416-424.

Williamson, T. (2010). Sprawl, Justice, and Citizenship : The civic costs of the American way of life. Oxford ; New York: Oxford University Press.

Wilson, W. J. (1987). The Truly Disadvantaged: The inner city, The underclass, and Public policy. Chicago :: University of Chicago Press.

Wilson, W. J. (1996). When Work Disappears : The world of the new urban poor (1st ed.). New York: Knopf : Distributed by Random House, Inc.

Wilson, W. J. (2009). More than Just Race : Being black and poor in the inner city (1st ed.). New York: Norton \& Company. 


\section{APPENDIX}

\section{UNIVERSITY OF LOUISVILLE}

Human Subjects Protection Program Office MedCenter One - Suite 200

$501 \mathrm{E}$. Broadway

Louisville, KY 40202-1798

Office: 502.852.5188 Fax: 502.852.2164
DATE:

TO:

FROM:

IRB NUMBER:

STUDY TITLE:

REFERENCE \#: IRB STAFF CONTACT:
August 10, 2016

John I Gilderbloom, Ph.D.

The University of Louisville Institutional Review Board

16.0648

THE SECTION 8 HOUSING PREMIUM: THE IMPACTS OF SECTION 8 HOUSING LOCATION ON HOME VALUES IN LOUISVILLE, KY

603881

Jackie Powell, CIP

852-4101

This study was reviewed on 08/10/2016 by the Vice Chair of the Institutional Review Board and approved through the Expedited Review Procedure, according to 45 CFR 46.110(b), since this study falls under Category 7: Research on individual or group characteristics or behavior (including, but not limited to, research on perception, cognition, motivation, identity, language, communication, cultural beliefs or practices, and social behavior) or research employing survey, interview, oral history, focus group, program evaluation, human factors evaluation, or quality assurance methodologies

This study was also approved through 45 CFR 46.116 (C), which means that an IRB may waive the requirement for the investigator to obtain a signed informed consent form for some or all subjects if it finds either:

- That the only record linking the subject and the research would be the consent document and the principal risI would be potential harm resulting from a breach of confidentiality. Each subject will be asked whether the subject wants documentation linking the subject with the research, and the subject's wishes will govern; or

- That the research presents no more than minimal risk of harm to subjects and involves no procedures for whic: written consent is normally required outside of the research context.

The following items have been approved:

\begin{tabular}{|c|c|c|c|}
\hline \multicolumn{4}{|l|}{ Submission Form } \\
\hline Initial Review Submission Packet & \multicolumn{3}{|c|}{ Approved as Submitted } \\
\hline Review Response Submission Form & \multicolumn{3}{|c|}{ Approved as Submitted } \\
\hline \multicolumn{4}{|l|}{ Study Application } \\
\hline Form Name & \multicolumn{3}{|c|}{ Outcome } \\
\hline IRB Study Application & \multicolumn{3}{|c|}{ Approved as Submitted } \\
\hline \multicolumn{4}{|l|}{ Study Document } \\
\hline Title & Version \# & Version Date & Outcome \\
\hline Online Survey & Version 1.0 & $08 / 02 / 2016$ & Approved \\
\hline Protocol & Version 1.0 & $08 / 02 / 2016$ & Approved \\
\hline Preamble & Version 1.0 & $08 / 02 / 2016$ & Approved \\
\hline Letter to be sent to subjects via email & Version 1.2 & 08/09/2016 & Approved \\
\hline Letter to be sent to subjects via email & Version 1.0 & $08 / 02 / 2016$ & Void \\
\hline
\end{tabular}


This study now has final IRB approval from 08/10/2016 through 08/09/2017.

For guidance on using iRIS, including finding your approved stamped documents, please follow the instructions at http://louisville.edu/research/humansubjects/iRISTutorials.pdf

\section{Site Approval}

If this study will take place at an affiliated research institution, such as KentuckyOne Health, Norton Healthcare or University of Louisville Hospital, permission to use the site of the affiliated institution is necessary before the research may begin. If this study will take place outside of the University of Louisville Campuses, permission from the organization must be obtained before the research may begin (e.g. Jefferson County Public Schools). Failure to obtain this permission may result in a delay in the start of your research.

\section{Privacy \& Encryption Statement}

The University of Louisville's Privacy and Encryption Policy requires such information as identifiable medical and health records: credit card, bank account and other personal financial information; social security numbers; proprietary research data; dates of birth (when combined with name, address and/or phone numbers) to be encrypted. For additional information: http://security.louisville.edu/PolStds/ISO/PS018.htm.

\section{Implementation of Changes to Previously Approved Research}

Prior to the implementation of any changes in the approved research, the investigator will submit any modifications to the IRB and await approval before implementing the changes, unless the change is being made to ensure the safety and welfare of the subjects enrolled in the research. If such occurs, a Protocol Deviation/Violation should be submitted within five days of the occurrence indicating what safety measures were taken, along with an amendment to revise the protocol.

\section{Unanticipated Problems Involving Risks to Subjects or Others (UPIRTSOs)}

In general, these may include any incident, experience, or outcome, which has been associated with an unexpected event(s), related or possibly related to participation in the research, and suggests that the research places subjects or others at a greater risk of harm than was previously known or suspected. UPIRTSOs may or may not require suspension of the research. Each incident is evaluated on a case by case basis to make this determination. The IRB may require remedial action or education as deemed necessary for the investigator or any other key personnel. The investigator is responsible for reporting UPIRTSOs to the IRB within 5 working days. Use the UPIRTSO form located within the iRIS system to report any UPIRTSOs.

Continuation Review Requirements

You are responsible for submitting a continuation review 30 days prior to the expiration date of your research study. Investigators who allow their study approval to expire have committed significant non-compliance with federal regulations. Such lapses may require reporting to federal agencies, a program audit by compliance auditors to ensure that subjects were not enrolled during the expired period, and may lead to findings of serious and continuing noncompliance if expiration were to occur a second time.

The committee will be advised of this action at a regularly scheduled meeting.

If you have any questions, please contact the IRB analyst listed above or the Human Subjects Protection Program office at hsppofc@louisville.edu.

Full Accreditation since June 2005 by the Association for the Accreditation of Human Research Protection Programs, Inc.

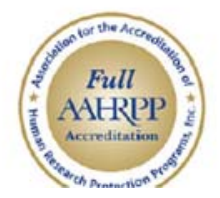


19. Emans Andui

Melissa Evans Andris, PhD, Vice Chair

Social/Behavioral/Education Institutional Review Board

MEA/jsp 


\section{CURRICULUM VITA}

\section{PAUL F. DRIES}

1609 Majestic Woods Place, Louisville, Ky 40245

paulfdries@yahoo.com

Phone: (502) 439-3040

\section{$\underline{\text { Education }}$}

- Ph.D. in Urban and Public Affairs, University of Louisville

Dissertation: Challenging Conventional Wisdom: Section 8 Housing and the Real Impact on Neighborhood Values in Louisville, KY

Committee: Dr. John Gilderbloom (Chair), Dr. Steven Koven, Professor Carrie Donald, Dr. Aaron Rollins, Dr. Matthew Hanka (University of Southern Indiana)

Approved October 24, 2016

- Master of Business Administration, Loyola University, New Orleans, Louisiana 1987

- Master of Engineering, (Civil Engineering), University of Louisville - 1983

- Bachelor of Science, (Civil Engineering), University of Louisville - 1982

\section{$\underline{\text { Licenses }}$}

- Board of Directors, Associate Member - Home Builders Association of Louisville 2008 and 2009

- Professional Engineer No. 28533, Kentucky

- Professional Engineer No. 78020, State of Texas (inactive) 
- Professional Engineer No. 22252, State of Louisiana (inactive)

\section{$\underline{\text { Academic Experience }}$}

University of Louisville

- Teaching Experience

o Adjunct Faculty for the Department of Industrial Engineering in the Master of Engineering Management program.

- Instructor for EM 670, Engineering Financial Management - Spring 2011; Fall 2012. Contact: John S. Usher, Ph.D., PE, Acting Dean, JB Speed School of Engineering.

- This course provides the engineering manager the tools to understand the financial condition of a firm through the use of income statements and balance sheets. Concepts presented include: discounted cash flow analysis, risk assessment, cost of capital and investment criteria. Semester project includes an evaluation and presentation of a publicly traded company.

- Student course evaluations resulted in 4.2 on a 5.0 scale for effectiveness.

o Graduate Teaching Assistant for Dr. Steven Bourassa.

- PLAN 634, Real Estate Finance and Investment - Spring 2011. Introduction to financial and investment analysis with applications to real estate.

- PLAN 634, Real Estate Finance and Investment - Spring 2011. Introduction to financial and investment analysis with applications to real estate.

- PADM 601, Statistics for Public Affairs - Fall 2010.

Course covers descriptive statistics, probability, sampling, tests of significance, correlation, regression analysis, and the use of statistical software packages.

- Real Estate coursework

o Urban Economics 
o Real Estate Market Analysis

O Real Estate Principles

o Land Use Planning

o Planning Theory

o Comparative Urban Development

- Attended and graduated from the 2010-2011 Graduate Teaching Assistant Academy at the University of Louisville. This course achieved the following objectives:

o Developed knowledge about the scholarship of teaching and learning in higher education.

o Provided reflective strategies to enhance teaching skills.

0 Interaction and learning from $U$ of $L$ faculty.

o Explored teaching perspectives with peers and mentors from across campus.

- Additional Activities

o Received an invitation and a grant to attend the May, 2012 Real Estate Research Institute (RERI) conference at DePaul University, Chicago, Illinois.

- Member of a multidisciplinary team that participated in the Spring 2012 Urban Design Competition sponsored by the Urban Land Institute and Gerald D. Hines. Prepared a comprehensive design and development program for a 17 acre site in downtown Houston, Texas that included drawings, site plans and financial data.

- Attended CCIM presentation by Dr. John Gilderbloom on January 18, 2012 -Contemporary Housing Dynamics: 10 Things to Improve Real Estate - 10 Things to Make It Worse

\section{Professional Experience}

Bakken Development Solutions, LLC Watford City, North Dakota 
dba BDS Land, performs land development activities, construction, and real estate consulting services in and around Watford City, North Dakota.

Chief Operating Officer 2013 to present

PFD, LLC Louisville, Kentucky

$P F D, L L C$ is a single-member entity, which performs land development activities and real estate consulting services in and around Louisville, Kentucky. (PFD) 2005 to present

NTS Development Company Louisville, Kentucky

NTS is a full-service, diversified real estate company with apartment homes, residential communities and commercial properties in the eastern United States. (NTS) 1995 to 2005

Friendswood Development Company Houston, Texas

Friendswood Development Company is Houston's premier master-planned community developer, offering communities spanning from the north to the south areas of Houston, Texas. (FDC)

1990 to 1995

Exxon Company U.S.A. Houston, Texas, New Orleans and Lafayette, Louisiana Exxon, now Exxon Mobil, is a fully integrated global oil \& gas operation. (EXN) 1982 to 1990

\section{$\underline{\text { Real Estate Development Experience }}$}

Mixed Use Development

- Responsible for Bakken Development Solutions, LLC activities in the oil rich western North Dakota region. Over 120 acres have been purchased and developed. Of this over 47 acres have been sold to entities such as 
ConocoPhillips, Value Place Hotels, RealSource Realty, Bakken Village, LLC, and W No. 2, LLC.

- Sales

$$
\begin{array}{cc}
\text { O } & 2013-\$ 4,156,000 \\
\text { O } & 2014-\$ 8,938,000 \\
\text { o } & 2015-\$ 1,459,000
\end{array}
$$

- BDS Land is a full-service development company specializing in providing the highest quality residential and commercial communities in the Bakken Region of North Dakota.

- BDS Land's mission is to create sustainable urban developments that incorporate affordable housing and innovative commercial property. These developments must benefit and strengthen the existing community.

- Activities include the identification of land positions, the acquisition and entitlement of these parcels, site development, and ultimate sale to the end user.

- Upon completion, these projects represent over $\$ 25 \mathrm{M}$ of development costs and infrastructure and sales in excess of $\$ 40 \mathrm{M}$.

- Part owner/developer/manager of River Breeze Apartments, a multifamily parcel in southwest Louisville, 12 acres and 150 units. (PFD)

o Property developed from raw acreage; zoning, design, construction, and management.

o Completed in 2012 , currently at $95 \%$ occupancy.

o Total project cost of $\$ 9,362,900$.

o Managed and administered HUD $221 \mathrm{~d}(4)$ financing for this project.

o These apartments have been developed with a goal of protecting the assets for long-term ownership and maintenance. Energy Star procedures and materials were used to facilitate sustainable development practices. Safety of the subcontractors and all visitors to the site has been a critical component of the project.

- Developer of the Heritage Hill Community in Shepherdsville, Kentucky. (PFD) 
o Planned and delivered 121 home sites, 90 patio home sites and an 18-hole championship golf course. Total construction budgets exceeded $\$ 10 \mathrm{M}$.

o Provided all cross-disciplinary communication between the community and the local regulatory agencies, utility companies, design engineers, contractors, utility companies and all advertising/marketing programs, sales, and accounting records for the community.

- Vice President of residential and commercial developments in the Louisville, Kentucky market. (NTS)

o Lake Forest (2,027 home-sites and 1,258 acres)

o Sutherland (300+ home-sites)

o Glenmary (100+ home-sites)

o Direct supervision of a staff of $10+$ employees.

o Evaluated new property acquisition while maintaining a complete understanding of the local land development code.

o Consulted on Fawn Lake development in Fredericksburg, Virginia

o Annual budgets for the projects under my direct responsibility averaged $\$ 10 \mathrm{M}$ in sales and $\$ 4 \mathrm{M}$ in construction projects.

- Responsible for all residential and commercial development, construction, utility and environmental studies in Clear Lake City, Texas. (FDC)

o Clear Lake City is a 15,000-acre Master Planned Community with an average of 593 lot sales annually for the four years I was there

o Directly supervised the work of over ten engineering and environmental consulting firms and eight construction firms

o Negotiated, administered and reviewed contracts for construction of site and community facilities including amenities and parks

o Developed business plans and budgets for neighborhood developments

o Served as a Community Association Board Member on four Community Associations 
o Reviewed and approved wetland delineation reports, environmental site assessments and cultural resource evaluations for land transactions in Clear Lake City.

o Activities also included major thoroughfare construction, regional parks, regional detention and sedimentation basin approval and construction

o Coordinated bond applications, sales and lease agreements for facilities, and developer recoveries for the real estate activities in the Clear Lake City Water Authority utility district.

\section{Other Business Experience}

- Financial Analyst and Project Engineer for offshore oil and natural gas operations $(E X N)$

o Performed the financial and technical assessment of proposed oil and natural gas exploration wells.

o Project engineer for several inland and offshore oil and natural gas fields. Optimized profit potential through the development and implementation of field depletion plans.

o Managed the prospect inventory database.

o Natural gas coordinator for the Offshore Division 